\title{
Investigation of Mechanical Breakdowns Leading to Lock Closures
}

Stuart D. Foltz 
The U.S. Army Engineer Research and Development Center (ERDC) solves the nation's toughest engineering and environmental challenges. ERDC develops innovative solutions in civil and military engineering, geospatial sciences, water resources, and environmental sciences for the Army, the Department of Defense, civilian agencies, and our nation's public good. Find out more at www.erdc.usace.army.mil.

To search for other technical reports published by ERDC, visit the ERDC online library at http://acwc.sdp.sirsi.net/client/default. 


\title{
Investigation of Mechanical Breakdowns Leading to Lock Closures
}

\author{
Stuart D. Foltz \\ U.S. Army Engineer Research and Development Center (ERDC) \\ Construction Engineering Research Laboratory (CERL) \\ 2602 Newmark Dr. \\ Champaign, IL 61824
}

Final Report

Approved for public release; distribution is unlimited.

Prepared for Headquarters, U.S. Army Corps of Engineers

Washington, DC 20314-1000

Under Project “Structural Monitoring System for Lock Structures to Prevent Failure” 


\section{Abstract}

The U.S. Army Corps of Engineers (USACE) owns or operates 236 locks at 191 sites, more than half of which have surpassed their 50-year design life. There are increasing concerns about their continued safe, reliable operation into the future, especially considering the fact that routine maintenance, lock dewaterings, and inspections sometimes occur at less than optimal intervals. Although critical repairs are prioritized, delayed maintenance increases the risk of failures that result in lock closures. One significant factor that contributes greatly to the difficulty of lock condition assessment is that much of the lock infrastructure typically remains under water. When a lock is dewatered, it is common to find previously unidentified distress, deterioration, and damage. To address such maintenance issues, there is an increasing need to gather more accurate information on repair needs and to prioritize those repairs. This work investigated types and frequencies of lock failures so that sensors can be used more effectively to identify imminent lock operational failures and concerns for ongoing lock reliability. Numerous data sources were used to collect these data, even though most of these sources were not created for the purpose of collecting the type of data the work investigated. The data gap is also discussed in the report.

DISCLAIMER: The contents of this report are not to be used for advertising, publication, or promotional purposes. Citation of trade names does not constitute an official endorsement or approval of the use of such commercial products. All product names and trademarks cited are the property of their respective owners. The findings of this report are not to be construed as an official Department of the Army position unless so designated by other authorized documents. 


\section{Contents}

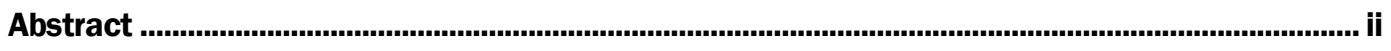

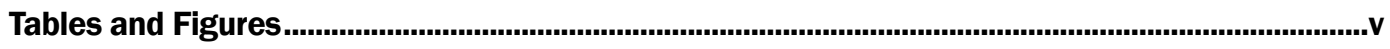

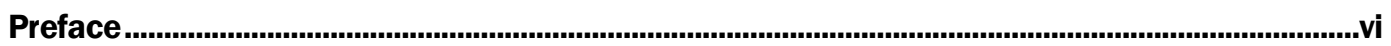

1 Introduction ............................................................................................................................... 1

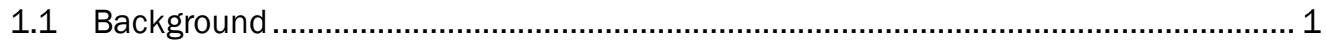

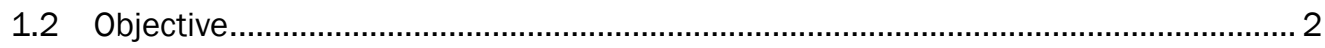

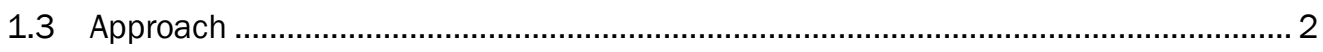

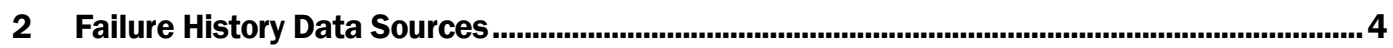

2.1 Lock Performance Monitoring System (LPMS) ..................................................... 4

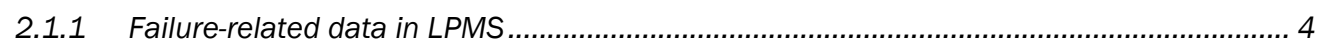

2.1.2 Definitions and descriptions of LPMS reason codes ..................................................... 6

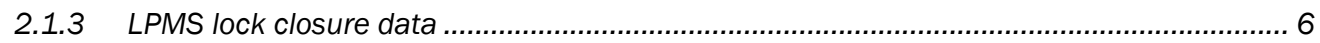

2.2 Headquarters Navigation Branch Emergency Closure Study (1999-2005)............. 8

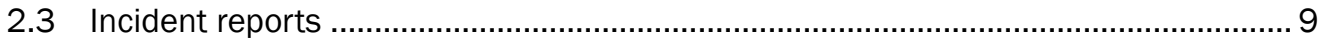

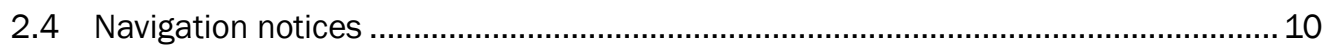

2.5 Lock logbooks and maintenance cards............................................................. 10

2.6 Division maintenance and repair records ......................................................... 11

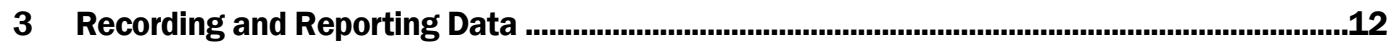

3.1 Facilities Equipment Maintenance (FEM) .................................................. 12

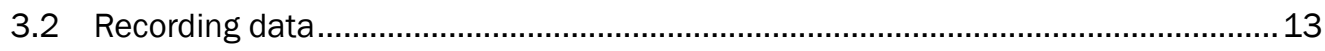

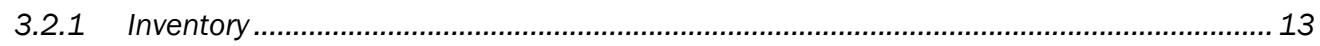

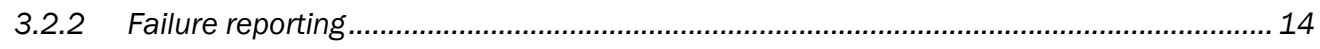

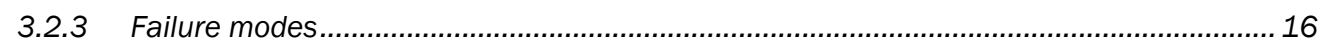

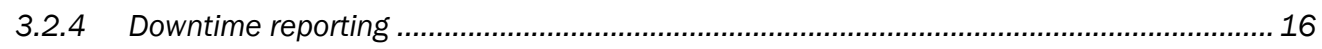

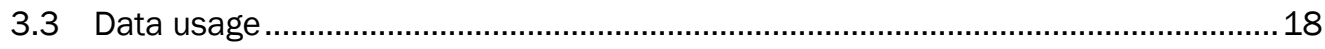

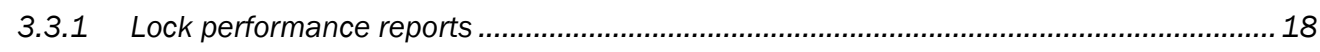

3.3.2 Service life and performance of components ............................................................ 21

4 Summary ..................................................................................................................................22

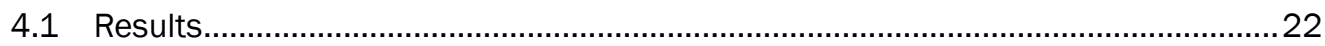

4.1.1 Mechanical breakdown data summary ...................................................................... 22

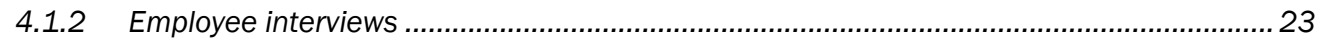

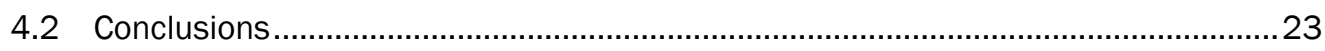

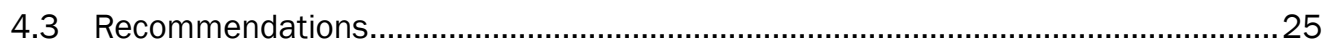

Appendix A: LPMS Reason Codes ...............................................................................................27

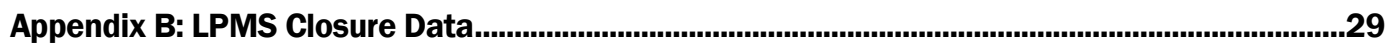

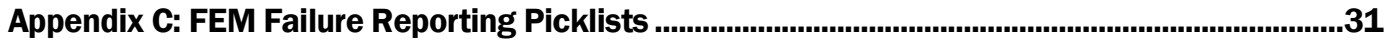




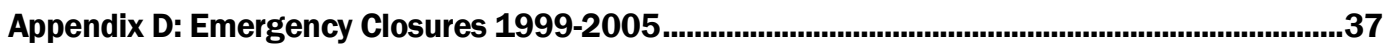

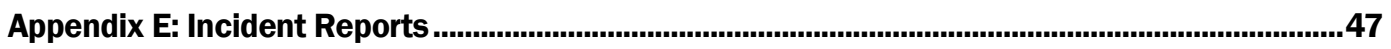

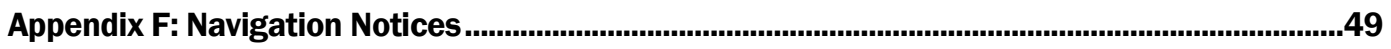

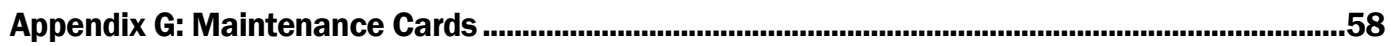

Appendix H: Major Maintenance and Repair Summaries ...........................................................60

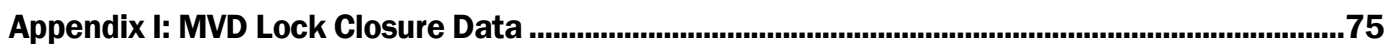

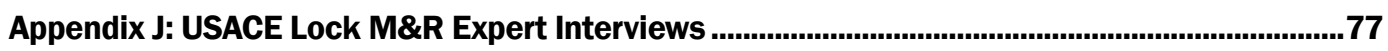

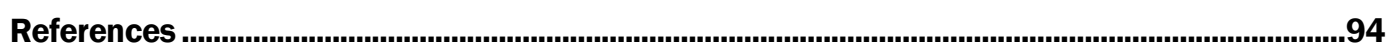

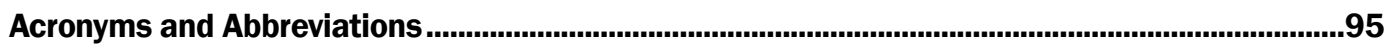

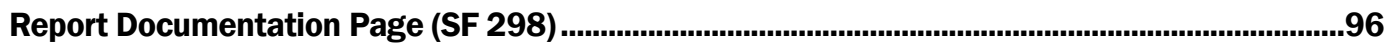




\section{Tables and Figures}

\section{Tables}

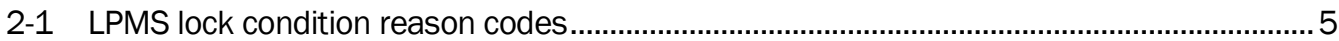

2-2 LPMS unscheduled lock conditions, 2007-13 …................................................................ 7

2-3 Types of emergency closures 1999-2005 .................................................................. 8

3-1 FEM Modules ..............................................................................................................

3-2 Navigation high priority performance goal for inland and intracoastal navigation operations and maintenance (O\&M) projects .................................................................20

4-1 Unscheduled mechanical closure conditions....................................................................22

\section{Figures}

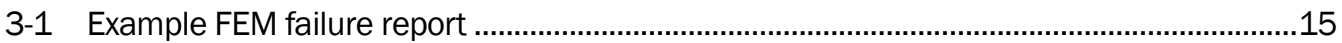

3-2 FEM downtime reporting selection ...............................................................................

3-3 FEM downtime (details) reporting selection .........................................................................

3-4 LPMS lock closures reported for campaign goal objective 3C..........................................18

3-5 Scheduled and unscheduled closures .............................................................................19

3-6 Increasing "downtime" at USACE locks on the inland waterways navigation .....................19 


\section{Preface}

This study was conducted for Headquarters, U.S. Army Corps of Engineers (USACE) under Project "Structural Monitoring System for Lock Structures to Prevent Failure" (Work Items 1F18B1, L93CJ 7, 4B1176). The technical monitor was William J . Lillycrop, Technical Director, Navigation.

The work was performed under the direction of the Materials and Structures Branch (CFM) of the Facilities Division (CF), U.S. Army Engineer Research and Development Center - Construction Engineering Research Laboratory (ERDC-CERL). At the time of publication, Vicki VanBlaricum was Chief, CEERD-CFM; Donald Hicks was Chief, CEERD-CF; and Kurt Kinnevan, CEERD-CZT, was the Technical Director for Installations. The Deputy Director of ERDC-CERL was Dr. Kirankumar Topudurti, and the Director was Dr. Ilker Adiguzel.

COL Bryan S. Green was Commander of ERDC, and Dr. David W. Pittman was the Director. 


\section{Introduction}

\subsection{Background}

The U.S. Army Corps of Engineers (USACE) owns or operates 236 locks at 191 sites (HQUSACE 2016). Although the locks at these sites generally perform reliably, more than half of these structures have surpassed their 50year economic design life, and as such, there are increasing concerns about their continued safe, reliable operation. Specifically, questions exist regarding the adequacy, cost, and effectiveness of routine maintenance, repair, and rehabilitation.

As locks age and components wear or otherwise deteriorate, there is a correspondingly greater need for closer monitoring of the infrastructure. However, despite the fact that lock infrastructure is aging, routine maintenance, lock dewaterings, and inspections sometimes occur less frequently than they have in the past due to fiscal limitations. Consequently, the repair backlog at some locations is increasing, leaving some gates to operate in less than optimal condition. For example, if gates have deteriorated paint or lack cathodic protection then structural section loss will increase.

Although critical repairs are prioritized, delayed maintenance increases the risk of operational or catastrophic failure that results in lock closures. In fact, scheduled closures (generally for maintenance and repair) and unscheduled closures due to weather, collisions, and other reasons beside compromised infrastructure reliability, cause far more lock closures than operational failure of the lock infrastructure. However, of all closures, unscheduled closures are generally more disruptive and costly to the commercial lock users.

There is a need to regularly assess the condition of locks to detect signs of imminent failure, to minimize unscheduled closure, and to ensure that scheduled closures for maintenance and repair (M\&R) are necessary and effective. One significant factor that contributes greatly to the difficulty of lock condition assessment, and that accounts for why lock repairs can be difficult to plan, prioritize, and accomplish is that much of the lock infrastructure typically remains under water. It is typical to assess lock conditions based on above water visual inspection, on equipment behavior when 
gates are operated, and sometimes also on underwater inspections. Nevertheless, it is common to find previously unidentified distress, deterioration, and damage when a lock is dewatered. Maintenance personnel expect a certain amount of unforeseen damage on dewatering, and are prepared to include some unexpected repairs. However, conditions where unforeseen damages exceed the capability to repair during the scheduled dewatering period can result in extended closure, or a return to operation with some infrastructure concerns unaddressed. This is an important issue since such uncompleted repairs can in turn lead to an increased frequency of dewaterings to maintain operational reliability.

To address these maintenance issues, there is an increasing need to gather more accurate information on repair needs and to prioritize those repairs. Improved, affordable sensor technologies that can perform real-time monitoring of lock and lock gate conditions may fill this need. This work was undertaken to investigate types and frequencies of lock failures so sensors can be used more effectively to identify imminent lock operational failures and concerns for ingoing lock reliability.

\subsection{Objective}

The objectives of this work were to:

1. Determine the conditions and other issues that currently lead to lock closures and/ or catastrophic failures

2. Identify sources of data that can be used to predict those lock closures and/ or catastrophic failures

3. Analyze the information to help identify how sensors may be used to collect useful information related to lock condition and behavior

4. Make recommendations to enable development of the data collection most appropriate to address these maintenance issues and that will help assign resources to maximize potential benefits.

\subsection{Approach}

This work investigated records of historic unscheduled outages due to lock gate failures to determine the operational issues to be assessed and reported to the lock personnel. It was assumed that historical data could provide information on the environmental events and component failures that have caused shutdowns. A number of relevant data sources were known and, in the course of this work, additional data sources were identi- 
fied. Further information was collected through interviews with experienced USACE employees who shared their insights and experiences related to lock operation, reliability, and repairs. From this collective information, an initial list of monitoring needs was developed based on a review and discussion of historical records. 


\section{Failure History Data Sources}

In order to use sensors and monitoring data to more effectively detect infrastructure conditions leading to unscheduled lock closure, it is critical to determine what components have historically led to closures, the conditions leading up to these failures, the specifics of the failure modes and how they can be detected most effectively. Only then can the monitoring be most effectively focused on the highest priority failure modes. This chapter discusses some of the relevant information sources and what was found when they were investigated.

\subsection{Lock Performance Monitoring System (LPMS)}

Data on scheduled and unscheduled lock closures are entered into LPMS. This is typically done by the lock operator, but can also be done by the lockmaster or other lock personnel such as equipment mechanics. Lock operators typically have less training and experience than other lock personnel or District engineers and technicians, and are often less familiar with the lock infrastructure. However, while LPMS is a good place to capture closures, it may not be as good for capturing data on infrastructure failures that result in unscheduled closures.

\subsubsection{Failure-related data in LPMS}

While LPMS can capture limited information on scheduled and unscheduled lock closures, it was not set up to capture failure data. It is an operational database primarily designed to capture lockages and tonnage. The following LPMS data fields relate to scheduled and unscheduled lock closures, including those attributable to failing or failed lock infrastructure:

- Location (Engineer Reporting Organization Code [EROC], River code, Lock \#)

- Begin stop date/ time

- End stop date/ time

- Scheduled (Y/N)

- Reason code.

LPMS includes 34 closures reasons in six different categories:

- weather conditions

- surface conditions

- tow conditions 
- lock conditions

- other conditions

- unknown.

Appendix A contains the entire list of LPMS reason codes. Of these six categories, only the lock conditions reason codes are clearly relevant to infrastructure issues. Reason codes to more specifically designate types of accidents and collisions would be useful. However, one would expect that the reason code "Accident or collision in lock" in the Lock Conditions category would be used if accidents or collisions occurred in the lock. Regardless, the reason codes most relevant to infrastructure issues relate to allisions and the four reason codes listed in bold in Table 2-1.

These LPMS codes do not provide details on what components were involved in causing the unscheduled closure. Missing details include:

- the specific component

- what happened to the component

- how the condition was discovered

- whether the lock was inoperable or if it was undesirable to continue operation

- how the condition impacted operation

- the age, condition, and maintenance history of the component.

Table 2-1. LPMS lock condition reason codes.

\begin{tabular}{|c|l|}
\hline Reason code & Description $^{*}$ \\
\hline AA & Accident or collision in lock \\
\hline BB & Closed (unmanned shift) \\
\hline EE & Repairing lock or lock hardware \\
\hline Q & Debris in lock recess or lock chamber \\
\hline R & Lock hardware or equipment malfunction \\
\hline M & Tow staff occupied with other duties \\
\hline T & Maintaining lock or lock equipment \\
\hline U & Ice on lock or lock equipment \\
\hline Y & Inspection or testing lock \\
\hline BBold-faced entries are the most relevant to infrastructure issues. \\
\hline
\end{tabular}




\subsubsection{Definitions and descriptions of LPMS reason codes}

In the course of investigating the LPMS data, it was learned that the specifics of many data fields are left undefined:

1. There is no standard definition of how to categorize closures as scheduled or unscheduled. An informal survey of engineers and managers responsible for maintenance and repair of navigation infrastructure resulted in a variety of opinions on how far in advance scheduled repairs must be announced, ranging from 72 hours to more than a year. The most relevant definition of unscheduled is any closure with a lead time too small to allow shippers time to adjust. This means that the lead time is different for every lock and will vary, typically by season.

2. One might expect that, if a reason code $\mathrm{R}$ (a malfunction) were entered into LPMS, it might be followed by reason code EE or possibly T or Y (repairing, maintaining, inspecting). On investigation of LPMS data, this was not found to be the case. Users entered one code or the other, but not both sequentially.

3. There are three slightly different reason codes for collisions or accidents that include both accidents and collisions. In one case, the collision is specifically in the lock. In another, the accident is a tow accident. Otherwise, the reason codes are non-specific. It appears that in two cases, accidents could include personnel from the tow having fallen overboard or become injured, as well as accidents involving other people. None of these codes mention allisions.

4. There is a reason code for debris and another for debris in the lock.

5. There is no guidance on which code to use if more than one is applicable to the situation.

6. There is no guidance on selecting whether the repair was scheduled or unscheduled. This would seem to bea straight-forward question but as discussed in the next section, the entered data is often not what might be expected.

Without clear definitions of the reason codes, there can be no expectation that closures due to similar conditions will be entered in LPMS using the same reason code.

\subsubsection{LPMS lock closure data}

LPMS data for scheduled and unscheduled closures from 2007 to 2013 were obtained and reviewed. Appendix B contains a sample of these records. The records for 2007 to 2011 were limited to entries of closures no longer than 1 month even when the closure extended much longer. These monthly records were combined. For the 7 years, there were 297 records 
listing unscheduled closures of greater than 24 hours for lock condition reason codes AA, EE, Q, R, S, and T. These records were further investigated by contacting district personnel. No further information was gained for 112 records. Of the remaining 185 records, 104 were determined to be for scheduled closures. Of the remaining 81 records, listed and categorized in Table 2-2, 45 were due to non-mechanical issues such as winter closures, debris, extended closures of auxiliary locks due to low priority, and extra days to complete scheduled repairs.

Table 2-2 roughly categorizes the mechanical breakdowns. None are for a component or in a gate location that is particularly frequent. Instead, there are a few breakdowns in each of many different locations. This makes sense. Among other factors, breakdowns occur due to design weaknesses, overstresses, wear out, and inadequate maintenance. One goal of the engineers and maintenance crews is to identify components that need maintenance or repair to avoid breakdowns. While they may have to focus more effort on certain components, one indicator of success is that no particular component of the gates suffers an inordinate number of breakdowns.

Table 2-2. LPMS unscheduled lock conditions, 2007-13.

\begin{tabular}{|l|c|}
\hline Condition & Occurrences \\
\hline Non-specific miter gate repairs, replacement, damage, failure, etc. & 8 \\
\hline Various gate gears issues & 3 \\
\hline Cable and chain issues & 0 \\
\hline Limit switch & 1 \\
\hline Hydraulics & 2 \\
\hline Gate anchorage, anchor bolts, anchor bars, pins, etc. & 2 \\
\hline Gate cracks or structural failure & 2 \\
\hline Barge accidents & 1 \\
\hline Electrical and power control issues & 0 \\
\hline Gate noise & 0 \\
\hline Gate vibrations & 0 \\
\hline Diagonal or strap & 5 \\
\hline Strut arm, attachment or pin & 4 \\
\hline Quoin block repairs & 2 \\
\hline Gudgeon & 2 \\
\hline Bottom seal & 0 \\
\hline Valve issues & 1 \\
\hline Pintle issues & 3 \\
\hline Various non-mechanical reasons & 45 \\
\hline
\end{tabular}




\subsection{Headquarters Navigation Branch Emergency Closure Study (1999-2005)}

Headquarters USACE Navigation Branch wanted to collect more detailed information on emergency closures than what was currently available from other sources. A data call was made to Districts and Divisions that resulted in the records (included in Appendix C). These records are the most detailed compiled listing of unscheduled lock closures that were found in the course of this investigation.

The text of the data call request was not available and details of the information sought were unclear. The data seem to indicate either the request was not very specific or some of the responders did not follow directions, whatever they were. For example, MVR reported closures for flood repairs at numerous locks in 2001, but there was no other mention of flood damage. There are only five instances of lock closure due to barge impact, although the USACE Great Lakes and Ohio River Division (LRD) reported many more barge impacts on the Ohio and Monongahela with no listed closure time. Unfortunately, while about 20 closures list gates that were repaired, replaced, changed, installed, etc., none mention specific issues. It is likely that some of the closures were not emergency closures and may have even been scheduled.

Table 2-3 lists these reported emergency closures roughly categorized by cause. (Appendix D includes a full listing.) If more specific descriptions were provided of the 21 emergency closures for non-specific miter gate repair, it might be possible to relate more closures to specific causes. However, as the data stand, the current list reinforces what was seen in the investigated LPMS closures. A wide variety of issues lead to emergency closures, yet no specific problem(s) that frequently cause unscheduled closures were identified.

Table 2-3. Types of emergency closures 1999-2005.

\begin{tabular}{|l|c|}
\hline Cause & Occurrences \\
\hline Non-specific miter gate repairs, replacement, damage, failure, etc. & 21 \\
\hline Various gate gear issues & 5 \\
\hline Cable and chain issues & 7 \\
\hline Limit switch & 0 \\
\hline Hydraulics & 3 \\
\hline Gate anchorage, anchor bolts, anchor bars, pins, etc. & 4 \\
\hline Gate cracks or structural failure & 7 \\
\hline
\end{tabular}




\begin{tabular}{|l|c|}
\hline Cause & Occurrences \\
\hline Barge accidents & 5 \\
\hline Electrical and power control issues & 1 \\
\hline Gate noise & 4 \\
\hline Gate vibrations & 4 \\
\hline Diagonal or strap & 4 \\
\hline Strut arm, attachment or pin & 3 \\
\hline Contact block repairs & 4 \\
\hline Gudgeon & 2 \\
\hline Bottom seal & 5 \\
\hline Valve issues & 2 \\
\hline Pintle issues & 2 \\
\hline Various non-mechanical reasons & 36 \\
\hline Flood damage repair (other repairs could be from flood damage) & 11 \\
\hline
\end{tabular}

\subsection{Incident reports}

EP 1130-2-520, Navigation and Dredging Operations and Maintenance Guidance and Procedures (HQUSACE 1996) requires districts to report accident and equipment failures through their Division office to Headquarters (italics added for emphasis):

EP 1130-2-520, Chapter 2

\section{2-6. Special Reports.}

a. Changes affecting navigation will be made promptly whenever information of immediate concern to navigation becomes known. Refer to ER 1130-2-520 for the circumstances requiring special reports. Items of information especially desired are: (1) channel condition as revealed by surveys; (2) changes in channel conditions, either by natural causes or by dredging or other work; (3) changes in approved projects for improvement with statements of results expected from proposed-operations; (4) descriptions of proposed dredging or other Federal work of improvement such as breakwater, pier, and revetment construction or alterations; (5) descriptions of proposed or completed municipal or private improvements in or affecting navigable waters; (6) accidents or equipment failures at USACE locks and dams or along navigable waterways, that will result in closure of the lock or waterway for 24 hours or more, or will result in a significant impact to navigation. For item (6), district commanders are to forward an incident report to HQUSACE (CECW-OD) 
through their MSC office as soon as possible following the incident. Reporting of navigation incidents to CECW-OD is required even though the districts may be sending situation reports to the HQ Emergency Operations Center during natural disasters or more regional or localized events.

Cursory checking indicates that personnel are aware of this requirement and that they typically comply. Because these are incident (and not failure) reports, they may not contain all the details such as make, model, age, etc., but they do often explain what component failed, and how and why it failed. Appendix E includes a sample incident report. Unfortunately, HQUSACE does not maintain an archive of these submittals. Although they do not typically include some of the desirable information, they would very likely provide a good understanding of the types of issues that lead to unscheduled equipment failures and accidents and contacts for additional information. The event descriptions could also provide details to supplement failure reports from other sources.

\subsection{Navigation notices}

Corps Districts typically post notices to industry of scheduled and unscheduled lock closures. These notices may occur long before the closure or after it has started. The notice will summarize the reason for the closure, include an estimate of when the lock will reopen or (for more uncertain situations) estimates of the next steps. Information on alternative routes, queuing, and locations for tows to wait may be included. While the notices will usually give a good indication of the cause of the closure, they do not typically give many of the details of what broke and why. Appendix F includes a sample navigation notice.

\subsection{Lock logbooks and maintenance cards}

At one time, many lock projects recorded nearly all maintenance, repairs, and infrastructure-related closures in a log book or on maintenance cards. With the introduction of LPMS and the Facilities Equipment and Maintenance (FEM) program, these paper records lost favor. In many locations, continued use of logbooks and maintenance cards was discouraged. Unfortunately, in many cases, the data were not captured in the newer electronic tools either. Increasingly few projects continue to maintain these records. Appendix $\mathrm{G}$ includes examples of various maintenance and repair records 
but logbooks and maintenance cards were not reviewed for useful information.

\subsection{Division maintenance and repair records}

Some projects, regional offices, Districts, and Divisions keep their own records of lock repairs and closures in addition to any standard USACE records. Appendix $\mathrm{H}$ includes two examples of summaries of repairs performed in the USACE Louisville District (LRL) and LRD, and Appendix I includes a summary of lock closures in the Mississippi Valley Division (MVD). The LRL record lists major issues addressed during dewaterings over a period of years. The LRD record lists scheduled, unscheduled, and performed repair and major maintenance data for LRD from 2005 to 2010. Often this type of information is collected post hoc, which can reduce the integrity of the information. Many of the dates for start and end of the closure do not match the data entered into LPMS. This may be due to a delay in entering the information, or it could be due to differences in perspective between the operators and engineers. The MVD list of lock closures is a new initiative that was not compared to LPMS closure data because the dates of obtained data only overlap for four closures. 


\section{Recording and Reporting Data}

To determine and predict lock infrastructure component failures, it is important to have good information on the reliability of lock components. USACE does not systematically collect information needed for estimating failure rates. The future of USACE data collection related to infrastructure reliability is likely to include the use of FEM. The open question is whether this will be accomplished in a way that provides robust data that include the details needed to accurately estimate reliability. This chapter, although not comprehensive, briefly discusses some of the concerns.

\subsection{Facilities Equipment Maintenance (FEM)}

FEM is a USACE software program based on the IBM product named "Maximo." FEM is primarily a maintenance management tool used for scheduling and tracking maintenance, parts, labor, other resources, budget items, and costs related to maintaining a given infrastructure. A key part of FEM is the use of job plans for recurring work, work requests for non-recurring work, and a tracking system for all work and related resources.

Table 3-1 lists the FEM modules and application available to support collection of cradle-to-grave asset costs.

Table 3-1. FEM Modules.

\begin{tabular}{|l|l|}
\hline Module & Description \\
\hline Asset Module Applications & $\begin{array}{l}\text { Used to track physical assets, to define relationships between } \\
\text { assets, and to manage assets throughout their life cycles. The } \\
\text { defined relationships serve to build asset hierarchies. }\end{array}$ \\
\hline Asset & $\begin{array}{l}\text { Used to build and store information about all aspects of } \\
\text { inventory materials, monitor the storeroom balance of inventory } \\
\text { items and tools, and track the cost of inventory stock reorder } \\
\text { items when stock is low. }\end{array}$ \\
\hline $\begin{array}{l}\text { Inventory Module Applications } \\
\text { Tools/Stocked Tools }\end{array}$ & $\begin{array}{l}\text { Used to create and manage Job Plan records, which contain job } \\
\text { tasks and information regarding estimated labor hours, } \\
\text { materials, services, and tools that are required for the work. }\end{array}$ \\
\hline Planning Module Applications \\
\hline Job Plans & $\begin{array}{l}\text { Used to create PM records (PMs) that can generate PM Work } \\
\text { Orders for documenting scheduled maintenance that is } \\
\text { performed on a time or meter-based frequency. }\end{array}$ \\
\hline Preventive Maintenance Module Applications
\end{tabular}




\begin{tabular}{|l|l|}
\hline Module & Description \\
\hline Purchasing Module Applications \\
\hline Purchase Requisitions & $\begin{array}{l}\text { Used to create and view purchase requisitions (PRS) for items, } \\
\text { supplies, and services. PR information is sent via an interface to } \\
\text { CEFMS from FEM. }\end{array}$ \\
\hline Resources Module Applications \\
\hline $\begin{array}{l}\text { Crafts } \\
\text { Qualifications }\end{array}$ & $\begin{array}{l}\text { Used to identify project/site/organization crafts (skill sets). } \\
\text { Used to create qualification records (i.e. certificates, licenses, } \\
\text { etc.) for use on Labor records to document employee's } \\
\text { qualifications. }\end{array}$ \\
\hline Work Orders Module Applications \\
\hline $\begin{array}{l}\text { Work Request and tracking } \\
\text { Labor Reporting }\end{array}$ & $\begin{array}{l}\text { Used to create basic work orders, report problems or } \\
\text { malfunctions, or request work to be done. } \\
\text { Used to create and process work orders from planning the work } \\
\text { to documentation of the labor, material and services used } \\
\text { (beginning to end). } \\
\text { Used to report hours of work performed against a Work Order. }\end{array}$ \\
\hline
\end{tabular}

As discussed in Section 2.5, before the introduction of FEM, many projects kept hardcopy maintenance records for their lock infrastructure. An important capability within FEM is routine maintenance management. A primary component of this is the use of a recurring scheduled maintenance plan. This has largely replaced the paper records. Labor requirements, parts, tools, and consumables can also be identified and readied for use based on requirements set up in FEM. Although FEM can also capture corrective maintenance, this data entry is not yet as well implemented within USACE. Some districts use FEM to record labor and track inventory.

FEM includes data fields for capturing information on the failure of components. It does this primarily through pick lists for Failure Classes, Problems, Causes, and Remedies. FEM presents opportunities for systematically capturing, organizing, and archiving information on faults and failures of infrastructure components. USACE has developed neither a policy nor objectives for collection of data regarding reliability of infrastructure. Section 3.2 further discusses information that might be collected to better determine the reliability of USACE infrastructure.

\subsection{Recording data}

\subsubsection{Inventory}

USACE has no comprehensive record of navigation components. Creating an inventory is a substantial effort but it is not just a failure reporting task. It is an integral step in implementing a maintenance management system 
such as FEM. All tasks need to be tied to a component. The quality and detail of the inventory will determine the effort to create it and the uses that can be made from it. Age, size, type, manufacturer, location, usage, and many other details can enhance capabilities to effectively and efficiently manage infrastructure.

Recording the installation date would seem relatively easy and straightforward, but it is not. The primary complication is determining whether a rehabilitated component is considered "new" when a portion of its parts have been repaired or replaced. Criteria for judging this can be created, but it will take a significant effort to do the job well. This work would require an initial effort to develop guidance that can be consistently applied across the inventory to identify the metrics for replaced (new) versus simply being repaired. The ambiguity of "repair" vs. "replace" can be minimized by focusing on the lowest level of components identification possible. Recording of size, type, manufacturer, etc. all present similar difficulties. It is important that individual items can be grouped according to similar parameters in order to assess their performance as a statistical group.

\subsubsection{Failure reporting}

Failure reporting is important for a number of reasons, but it basically comes down to determining and recording what fails, how often, why, under what conditions, and with what consequences. FEM includes a work order page for recording the failure class, problem, cause, and remedy (Figure 3-1). Appendix Cincludes a full list of failure classes, problems, causes, and remedies.

At first glance, failure reporting seems to be quite simple. However, it is not. Each of the questions in the previous paragraph needs to be approached in a direct and explicit fashion to capture the desired information. Failure reporting must be accomplished using standardized categories to create usable failure statistics such as:

- What has failed? Identifying what has failed must be done in a consistent way. That means using classifications to identify the component and attributes to identify details such as the manufacturer, size, etc.

- How often? This is the best basis for estimating failure rates. It may also help identify systemic problems. The occurrence of a failure needs to be precisely defined. Is it based on a repair, subcomponent replacement, overhaul, total replacement, another basis, or some combination of these? The answer will determine how the data can be used. 
- Why? The most valuable data are those that identify the failure mode. It makes a difference whether electric motor failures are from bearings that have been inadequately lubricated (and should be maintained), or from a short in the motor windings that cannot be maintained, but that might indicate a manufacturer defect.

- What conditions? If every USACE lock were constructed with a similar design, size, usage, operating environment, etc., determining failure rates could be done more accurately. There are a number of ways to capture these operating conditions, but it will require extensive forethought to most effectively account for these variables.

- Suspensions? How are replacements before failure to be recorded?

- What consequences? Should a failure be reported based on a stall, stoppage, non-routine application of maintenance, or other criteria?

Figure 3-1. Example FEM failure report.

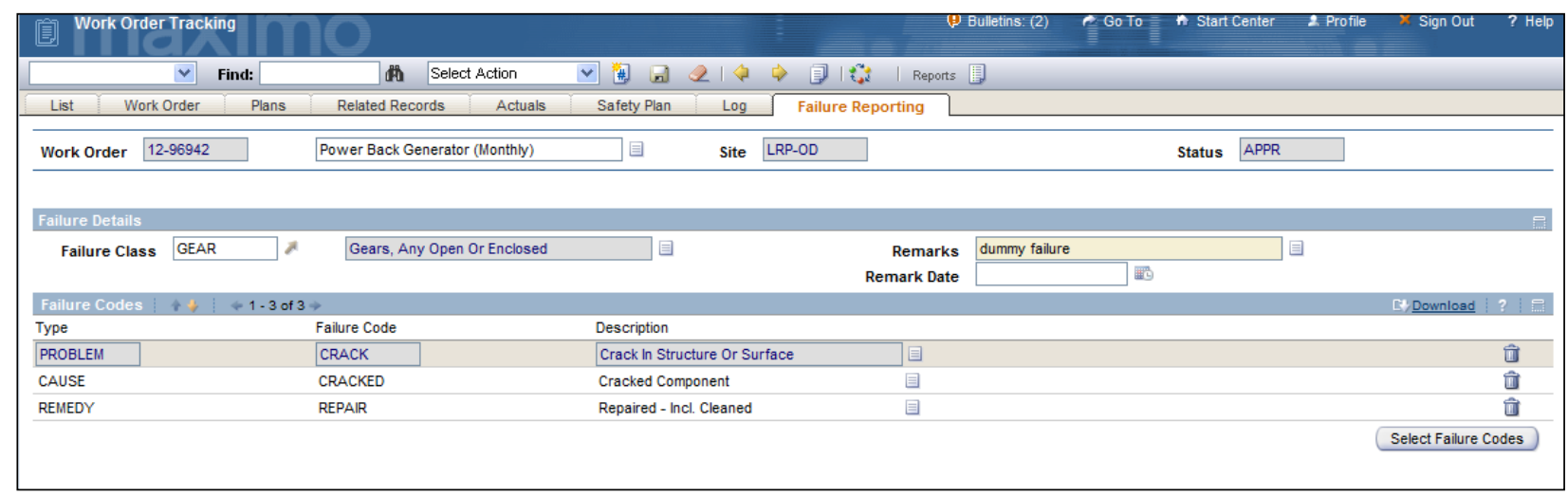

With adequate data points and detail, failure data can assist in many ways. First, they can allow a statistical calculation of past failure rates. This is important for verifying estimates used in risk analysis. Failure data can also help identify common causes of failures, maintenance deficiencies, manufacturing defects, design flaws, and other system faults.

While failure data information is useful, it likely needs to be supplemented with additional information. Useful supplementation includes: (1) information that can be collected in FEM, such as age, (2) information that should be collected as standardized attributes, such as the manufacturer, model, size, etc., and (3) information such as condition as it relates to the specific failure mode. While this last piece of information (condition) could be accomplished by extensive data collection, possible alternatives could include post-failure estimates and automated condition monitoring. 


\subsubsection{Failure modes}

Recording failures unambiguously also requires a focus on failure modes. Wiebull models are only meaningful when applied to failure data collected at this level. Because USACE operates locks of unique designs, loadings, and usage with diverse components of varying size and manufacture in diverse environments, good failure data also require more information to determine the contribution of each failure mode to the observed failures. The question is how this information should be captured. Demand relative to capacity is important, but it seems reasonable to ignore this factor for most USACE lock infrastructure, which is usually designed for much higher loads than are typically encountered. In USACE, usage or loading cycles are very important. Age may also be useful as a crude approximation of many contributors to failure, although age does not account for the uniqueness of each USACE structure. One way to capture that uniqueness is by using condition ratings that focus on each failure mode to develop a failure rate relationship based on usage and condition.

\subsubsection{Downtime reporting}

Currently, FEM makes no direct connection between downtime reporting and failure reporting, although both must be tied to a work order. Downtime reporting differs from failure reporting in that it is primarily concerned with recording what asset is unavailable and the duration of the outage. Figures 3-2 and 3-3 show the entry of this information into FEM. Note that downtime reporting is based on what is occurring during the downtime and does not include information on what led to the downtime. It also does not specifically distinguish between scheduled and unscheduled downtime.

There are presently five choices for types of downtime (Figure 3-3). Note that the list does not include any type of weather-related downtime, nor does it allow recording a boat accident, personnel injury, or other causes not listed in FEM. Although it is possible to record lock stoppages and shutdowns within the downtime reporting, there is no obvious best way to do that and there is currently no guidance on how it should be done. As a result, if a project started using FEM to record shutdowns, it is likely those shutdowns would be recorded in different ways across USACE so that it would be difficult to compile a history of shutdowns and their causes. 
Figure 3-2. FEM downtime reporting selection.

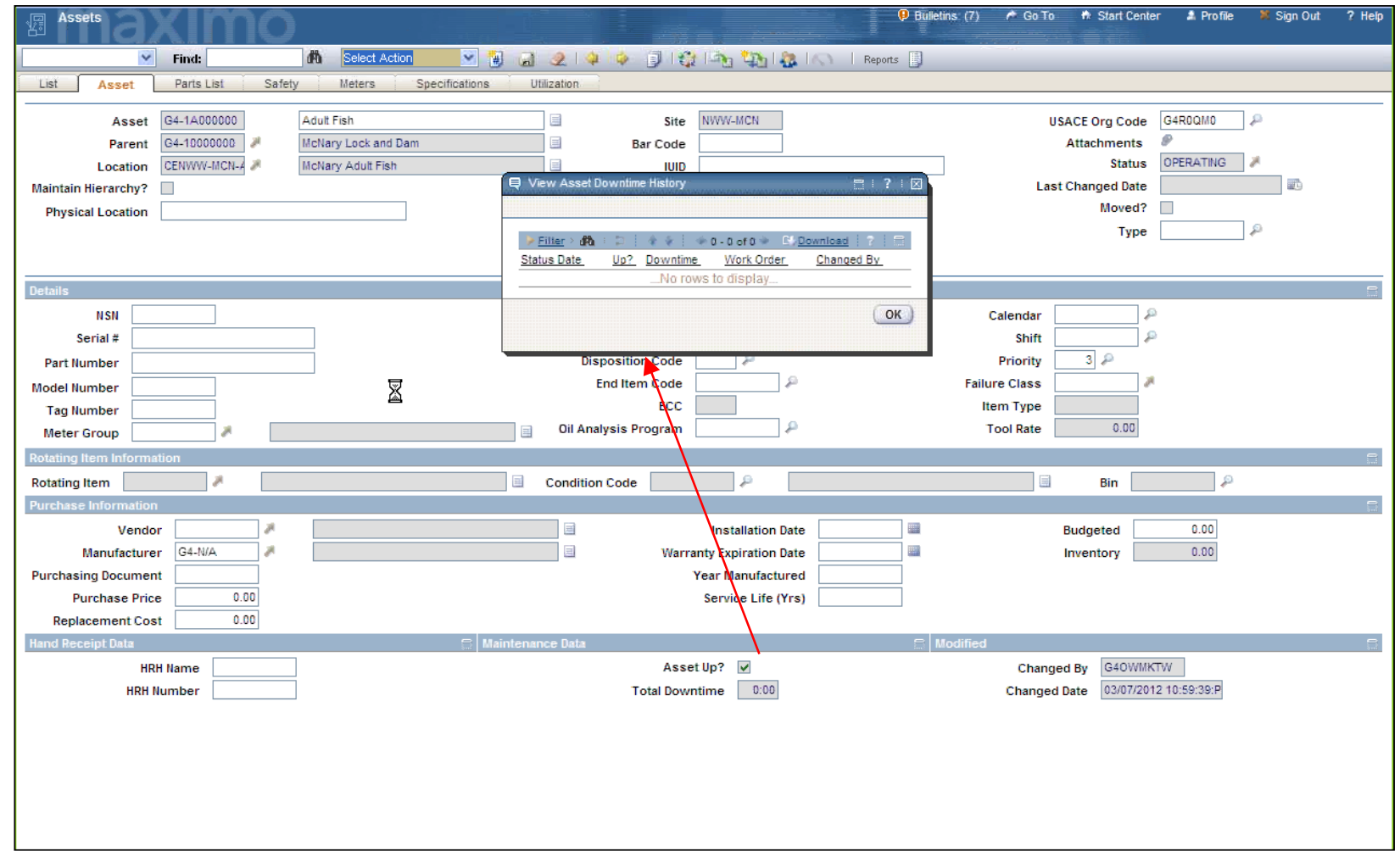

Figure 3-3. FEM downtime (details) reporting selection.

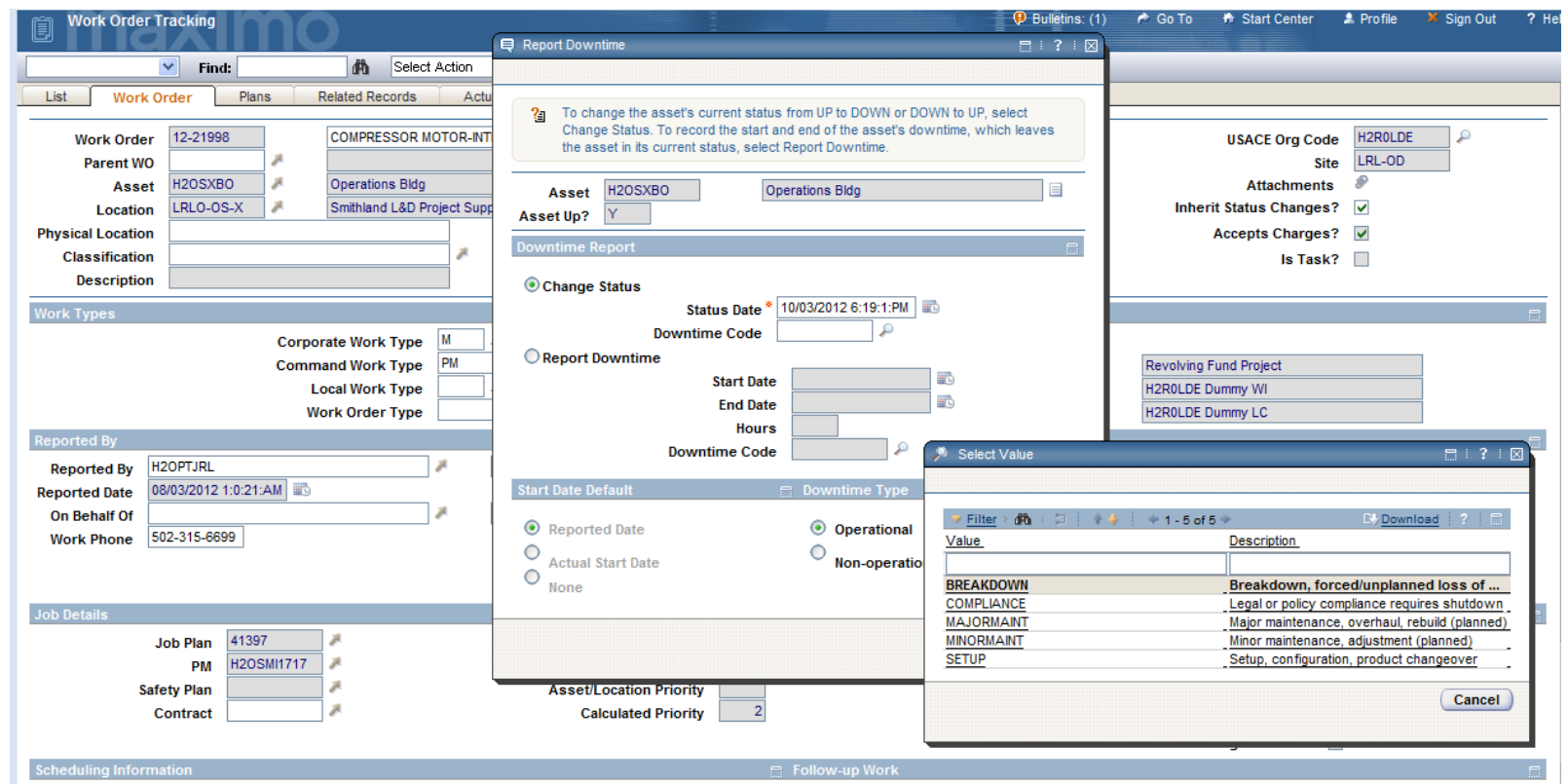

While there is no direct connection in FEM between downtime reporting and failure reporting, both are tied to a work order. That link within the user interface is weak because failure reporting is located on a work order tab and downtime reporting is on a pull-down menu but if both records for 
an event are entered, they can be associated. It would be better if the user interface included a stronger link between the two. One option would be to prompt the user to enter a downtime report when exiting the failure reporting module and provide a similar prompt when exiting the downtime report.

\subsection{Data usage}

\subsubsection{Lock performance reports}

Until recently, the USACE Campaign Goal Objective 3C was to "Deliver reliable infrastructure using a risk-informed asset management strategy." For navigation, accomplishment of this goal was measured by looking at LPMS data for scheduled and unscheduled closures lasting longer than 1 day, and 7 days. See Figures 3-4, 3-5, and 3-6 and Table 3-2. This information has been included in numerous publications and presentations.

It was useful and informative to separate unscheduled closures attributed to mechanical breakdowns from other unscheduled closures. Unfortunately the LPMS reason codes used to identify unscheduled mechanical breakdowns (Table 2-1) include debris, icing, unmanned shifts, lock staff unavailable, and accidents in the lock, such as "man overboard" and potentially even allisions (although no LPMS reason code description specifically mentions allisions). If the goal is to determine infrastructure reliability, including closures for those reasons creates ambiguity.

Figure 3-4. LPMS lock closures reported for campaign goal objective 3C.

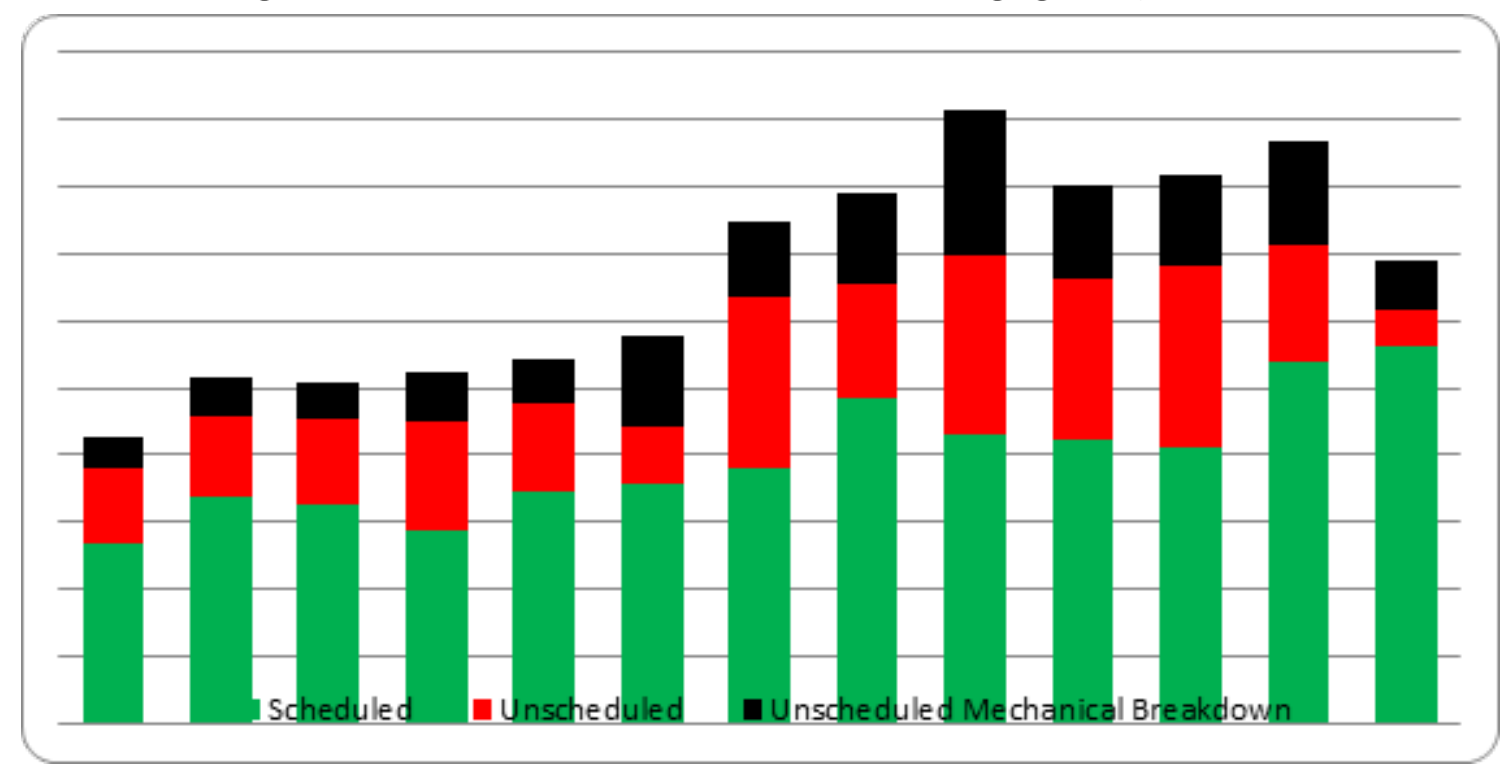


Figure 3-5. Scheduled and unscheduled closures.

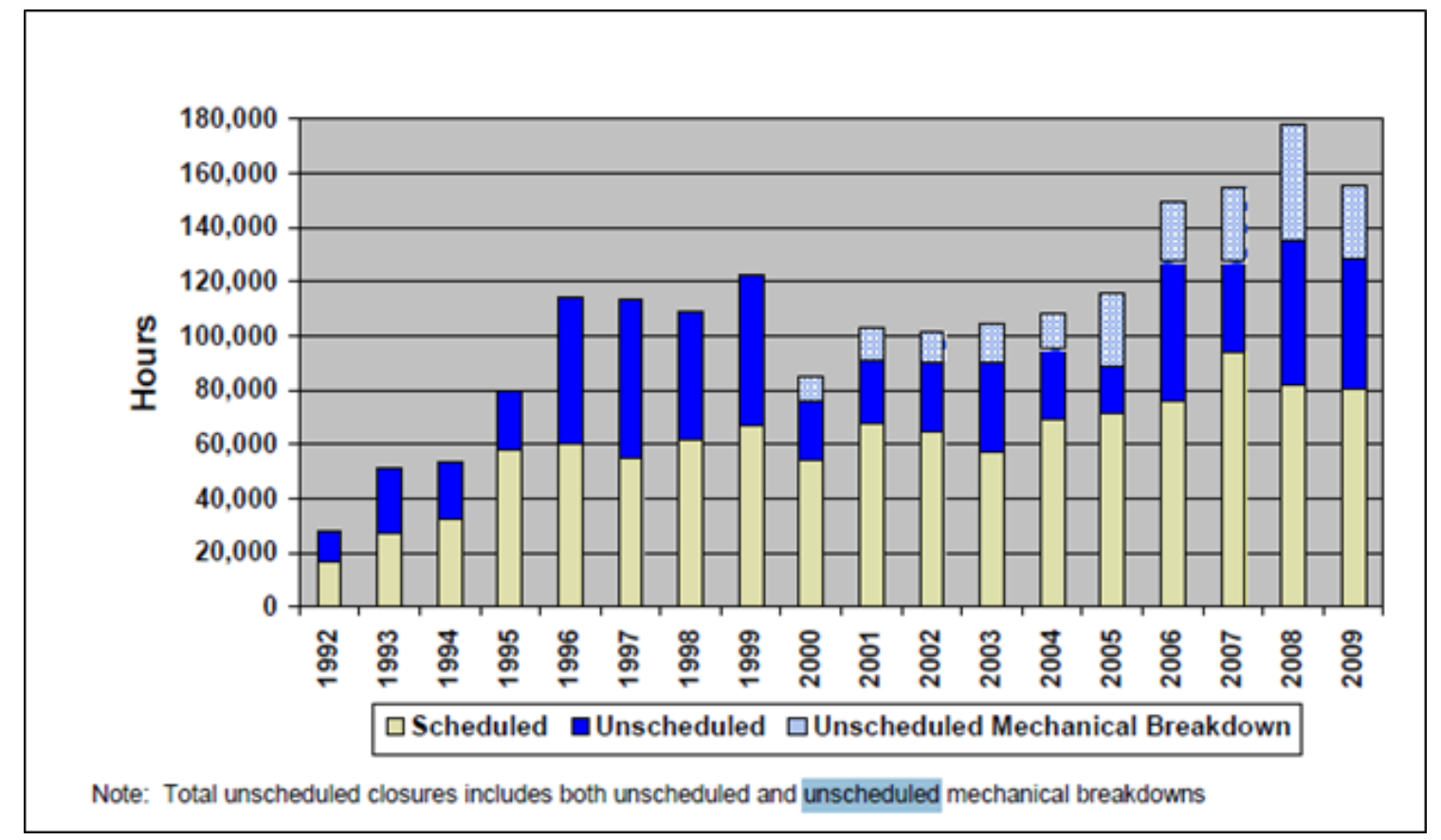

Figure 3-6. Increasing "downtime" at USACE locks on the inland waterways navigation.

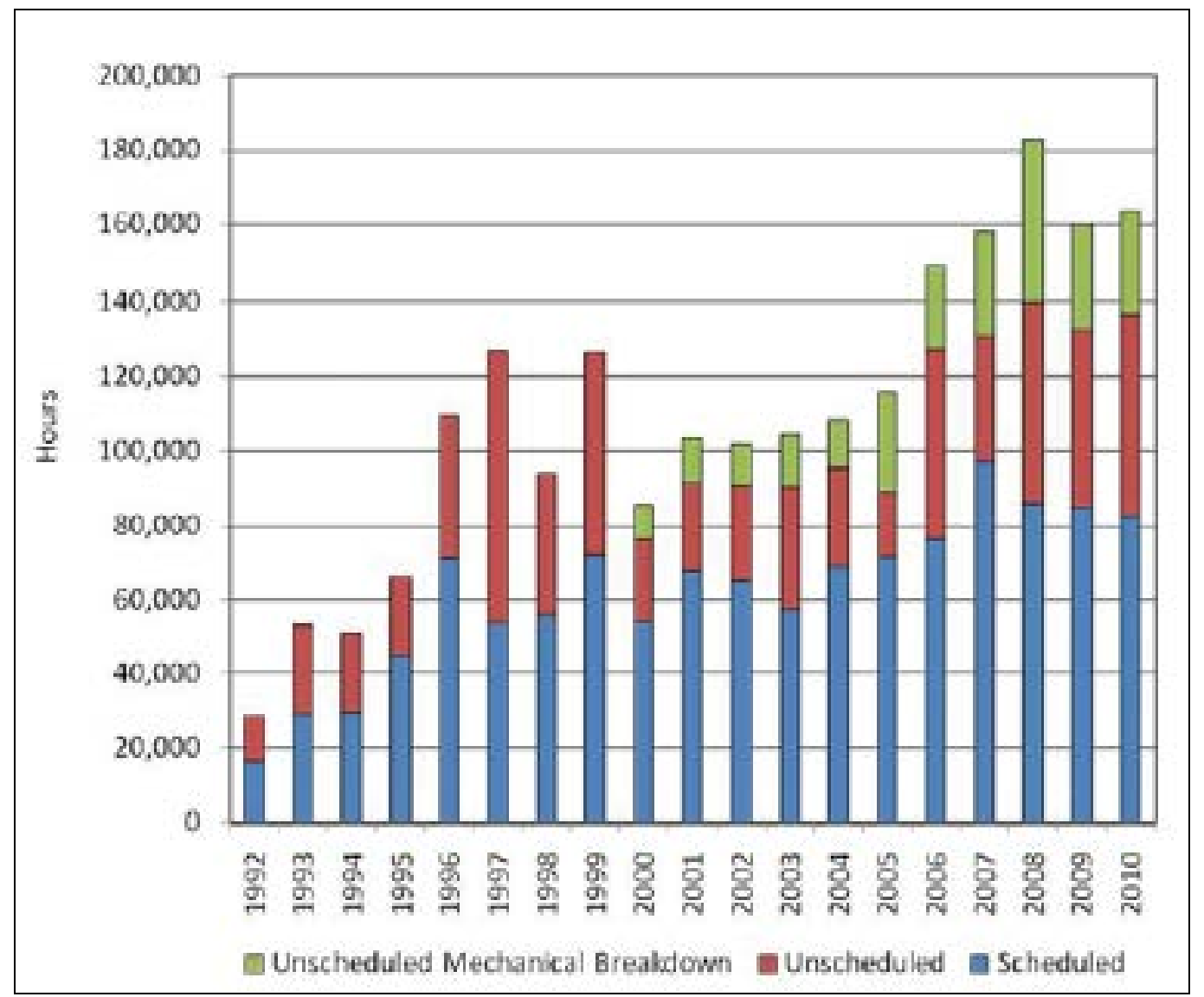


Table 3-2. Navigation high priority performance goal for inland and intracoastal navigation operations and maintenance $(0 \& M)$ projects.

\begin{tabular}{|c|c|c|c|c|c|c|c|c|c|c|}
\hline Fiscal Year & 2002 & 2003 & 2004 & 2005 & 2006 & 2007 & 2008 & 2009 & 2010 & 2011 \\
\hline $\begin{array}{l}\text { Appropriation } \\
\text { (\$ Millions) }\end{array}$ & NA & NA & NA & $\$$ & $\$ 501$ & $\$ 491$ & $\$ 523$ & $\$ 660$ & $\$ 886$ & NA \\
\hline $\begin{array}{l}\text { Target- Instances of } \\
\text { Lock Closures due } \\
\text { to Mechanical } \\
\text { Failures Lasting } \\
\text { Longer than } 24 \\
\text { Hours }\end{array}$ & NA & NA & NA & NA & NA & NA & NA & NA & 37 & 38 \\
\hline $\begin{array}{l}\text { Actual Instances of } \\
\text { Lock Closures due } \\
\text { to Mechanical } \\
\text { Failures Lasting } \\
\text { Longer than } 24\end{array}$ & & & & & & & & & & \\
\hline $\begin{array}{l}\text { Hours } \\
\text { Total Hours for Lock } \\
\text { Closures due to } \\
\text { Mechanical Failures } \\
\text { Lasting Longer than }\end{array}$ & 45 & 45 & 36 & 19 & 33 & 38 & 42 & 37 & 61 & NA \\
\hline $\begin{array}{l}24 \text { Hours } \\
\text { Target- Instances of } \\
\text { Lock Closures due } \\
\text { to Mechanical } \\
\text { Failures Lasting }\end{array}$ & 13,448 & 12,575 & 9,265 & 5,029 & 9,817 & 9,317 & 16,033 & 11,096 & 19,562 & NA \\
\hline $\begin{array}{l}\text { Longer than } 7 \text { Days } \\
\text { Actual Instances of } \\
\text { Lock Closures due } \\
\text { to Mechanical } \\
\text { Failures Lasting }\end{array}$ & NA & NA & NA & NA & NA & NA & NA & NA & 19 & 21 \\
\hline $\begin{array}{l}\text { Longer than } 7 \text { Days } \\
\text { Total Hours for Lock } \\
\text { Closures due to } \\
\text { Mechanical Failures }\end{array}$ & 25 & 27 & 19 & 13 & 21 & 18 & 28 & 19 & 37 & NA \\
\hline $\begin{array}{l}\text { Lasting Longer than } \\
7 \text { Days }\end{array}$ & 12,255 & 11,399 & 7,929 & 4,728 & 8,871 & 7,805 & 15,073 & 9,675 & 17,638 & NA \\
\hline
\end{tabular}

In addition to ambiguous or inapplicable closure codes, the limited investigation of LPMS data discussed in Section 2.1.3 indicates that the criteria used to determine whether a closure is "scheduled" or "unscheduled" are poorly defined and often not entered accurately. One particular example is the entry of month-long unscheduled closures in December, J anuary, and February as EE-Repairing. These closures account for a large portion of the hours identified as unscheduled mechanical breakdown. While repairs may be occurring, the closure is in fact due to ice-related river and lock conditions. Similarly, an auxiliary lock may be closed for repairs for an extended period because it is a low priority to return to service quickly. The reduction in 2012 for unscheduled mechanical breakdowns comes largely from a reduction in entries of these two reasons. In the case of scheduled closures, it is useful to determine how often locks are closed for scheduled maintenance, inspection, and repair. However, a tabulation of all scheduled closures will include other reasons that may create ambiguity. For example, the decision not to staff some locks 24/ 7 increases scheduled closures. Clearly, if LPMS data are going to be used for metrics such as an USACE Campaign goal, the LPMS data must be relevant to the metric. It 
may even be necessary to change the manner in which the LPMS data are collected.

\subsubsection{Service life and performance of components}

Comprehensive data on the life cycle (installation through replacement) of infrastructure components would create numerous options for planning and risk management. If USACE is to implement a fully functioning risk management program, it is critical to progress from subjective opinion based failure probabilities to statistics based estimates. This cannot be accomplished without collection of data related to failure of components as previously described.

In addition to risk analysis and other uses related to repair prioritization and budgeting, failure statistics (along with maintenance records) can help identify best practices for design and maintenance.

There are many different fender designs used throughout USACE. Local experience is important but without good service life data, there is no objective way to measure the cost-benefit of alternative designs which vary greatly in initial cost and service life or measuring the effects of weather, barge impacts, and other considerations.

Scheduled maintenance (or insufficient maintenance) can extend the life of infrastructure. Excessive maintenance does little good and in some cases can reduce the service life. Optimizing the maintenance based on past results can yield significant savings.

A history of repairs and component replacements with consistent recording of the cause can help identify defective components as well design or operational shortcomings. 


\section{Summary}

\subsection{Results}

\subsubsection{Mechanical breakdown data summary}

While data are potentially available from numerous sources, this effort only found usable data available from two USACE-wide sources (LPMS and the Headquarters (HQ) data call described in Section 2.2) Data from LPMS need further investigation to obtain the minimum necessary details. Although the years covered by the two sources are discontinuous, the combination of these two sources (Table 4-1) yields a better indication of the conditions leading to unscheduled mechanical closures. The results indicate that there are a large number of conditions of similar frequency that lead to these closures.

Table 4-1. Unscheduled mechanical closure conditions.

\begin{tabular}{|c|c|c|c|}
\hline Description & Table 2-2 & Table 2-3 & Combined \\
\hline $\begin{array}{l}\text { Non-specific miter gate repairs, replacement, damage, } \\
\text { failure, etc. }\end{array}$ & 8 & 21 & 29 \\
\hline Various gate gear issues & 3 & 5 & 8 \\
\hline Cable and chain issues & 0 & 7 & 7 \\
\hline Limit switch & 1 & 0 & 1 \\
\hline Hydraulics & 2 & 3 & 5 \\
\hline Gate anchorage, anchor bolts, anchor bars, etc. & 2 & 4 & 6 \\
\hline Gate cracks or structural failure & 2 & 7 & 9 \\
\hline Barge accidents & 1 & 5 & 6 \\
\hline Electrical and power control issues & 0 & 1 & 1 \\
\hline Gate noise & 0 & 4 & 4 \\
\hline Gate vibrations & 0 & 4 & 4 \\
\hline Diagonal or strap & 5 & 4 & 9 \\
\hline Strut arm, attachment or pin & 4 & 3 & 7 \\
\hline Quoin block repairs & 2 & 4 & 6 \\
\hline Gudgeon & 2 & 2 & 4 \\
\hline Bottom seal & 0 & 5 & 5 \\
\hline Valve issues & 1 & 2 & 3 \\
\hline Pintle issues & 3 & 2 & 5 \\
\hline Various other reasons & 45 & 28 & 73 \\
\hline $\begin{array}{l}\text { Flood damage repair (other repairs could be from flood } \\
\text { damage) }\end{array}$ & & 11 & 11 \\
\hline
\end{tabular}




\subsubsection{Employee interviews}

Although the data collected give some indication of the common lock infrastructure problems leading to unscheduled closures, the data are still very limited and give neither a complete picture of the infrastructure issues, nor an accurate quantification of the extent that infrastructure issues lead to lock closures. To supplement the collected data and to gain further insights, it was decided to survey various USACE employees. A number of questions were asked of six senior USACE employees to gain their knowledge regarding unscheduled mechanical closures and also to gather their knowledge and opinions on how locks are and should be maintained. Appendix J includes copies of the questions and the experts' paraphrased responses. The questions were first briefly discussed with most of the experts by teleconference. Further comment was obtained from the experts individually either in writing or by interview. These further comments are shown in bolded font.

While each expert expressed their own particular concerns, the most common issue they identified was the need to gather information needed to plan repair work while the locks are dewatered. Details on needed repairs below the water line and the extent of these needed repairs must be based on reports of conditions after the previous dewatering repairs, updated with operational information such as noises and vibrations, and with information gathered by underwater inspection by divers. This information is often inadequate. Surprises are frequent and it can be difficult to accomplish the unplanned repair work in the allotted time.

\subsection{Conclusions}

USACE owns a large inventory of civil works structures, each of which is unique. Typically, there are few or no components in any one structure that are of the same make, model, size, manufacturer, designer, constructor, environment, or operational history as those in any other USACE structure. Furthermore, operation, maintenance, repair and rehabilitation is overseen by lock personnel, maintenance crews, engineers, and others, in multiple districts, all of whom differ in their experience and in their expectations of how the structures should be operated and maintained. These are only two of many factors that make it difficult to develop a comprehensive listing of conditions and other issues that currently lead to lock closures and/ or catastrophic failures at all USACE locks. 
This work reviewed data from 236 locks at 191 USACE sites and identified 119 unscheduled lock closures of durations over 24 hours that occurred due mechanical breakdowns. Of the 119 closures, records documenting 29 of the closures focused broadly on the miter gates. Eighty-five of the remaining 90 closures were attributed to the failure of 14 specific components, each of which caused four to nine closures. Note that these data were not exhaustive; better data collection would have yielded far more detailed reports, which would in turn have enabled better analysis of the noted closures. For example, data from one source were collected post hoc; data for the other period included only about $40 \%$ of the records.

This work attempted to augment these data with information culled from historical records, with some limited success. Based on the limited data collected, the conditions and causes -i.e., mechanical breakdowns and other infrastructure-related issues (such as allisions) - that led to these unscheduled lock closures appear to be highly varied. Some closures were attributed to combinations of many issues, and no single issue was identified as the cause of many closures. While the mechanical breakdowns leading to unscheduled closures are quite varied, there are a smaller number of issues of more frequent concern during scheduled maintenance.

USACE does not systematically track the causes of lock mechanical breakdowns. Data currently collected lack sufficient detail to allow a failure analysis beyond expert judgment of those involved. Similarly, USACE currently has only marginally applicable, incomplete data for estimating the reliability of infrastructure components. Component reliability is primarily determined based on subjective expert opinion, or on metrics that are themselves based on that expert opinion. This lack of objective, historical data makes it difficult to meaningfully identify or prioritize how to improve the reliability of a particular structure (or set of structures).

USACE does have the ability to collect data on mechanical breakdowns and reliability through existing available systems, specifically, LPMS and FEM. These systems could be better used to collect data in enough detail to form a real-time record of component failures and replacements could enable the identification of components with unacceptably low reliability. However, existing data are inadequate to support calculations of historical life averages and other statistical measures to in-service components. As 
currently recorded, that data in each of these systems appear to have limited value in tracking mechanical breakdowns and reliability for many reasons, including, but not limited to:

- data availability (i.e., whether data are even collected)

- the intent of data collection

- data consistency (definition of what should be collected)

- data accuracy (requirements for what data is collected)

- data preservation.

Collection of more adequate data would be useful in identifying common issues and in identifying ways to reduce breakdowns most effectively through redesign, timely maintenance and inspection, improved dewatering effectiveness, automated data collection (sensors), and other methods. Because it is difficult to identify specific needed M\&R (and the extent of that $M \& R$ ) before dewatering, better information on repair needs before dewatering could assist in planning for M\&R while dewatered, and could help shift schedules for dewatering from a time-based to a condition-based schedule.

\subsection{Recommendations}

While lock monitoring development efforts should continue to investigate how to identify impending mechanical breakdowns, an effort should also be made to capture relevant information to determine what needs to be repaired regardless of the short-term failure likelihood. The hidden nature of many developing distresses, particularly of those underwater, makes it imperative to gather consistent, accurate information that may be used to plan repairs long before failure is likely or impending.

This work recommends that USACE begin to systematically collect data on mechanical issues, failures, and replacements as they occur, in sufficient detail to determine the reliability of in-service components. Specifically, this work recommends that USACE standardize this data collection on the use of the Facilities Equipment and Maintenance (FEM) system, which is clearly the best option to collect and store this information. One potential benefit of using a single system to collect and compile data on operations and infrastructure is that it allows a standardization of the information used for performing statistical analysis. To fully reap the potential benefits this system can offer, the data must be collected in a uniform and con- 
sistent manner. This is not currently being accomplished with infrastructure-related data within LPMS and FEM. To that end, it is recommended that detailed instructions be created and given to personnel on the data that must be collected, and how to consistently and accurately enter that information into FEM.

It would require a substantial effort to determine the failure reporting data needed for developing meaningful failure statistics. Recording of the information by project and district personnel would also be a significant effort. While LPMS is not intended for failure reporting, and it does not provide a good opportunity for collecting the best information, small improvements in LPMS data fields, reason codes, and user instructions could result in more meaningful data with little or no additional effort.

Navigation Notices have historical information that may be of some value, and incident reports include highly valuable information. These documents should be archived for future use. It was confirmed that the HQUSACE POC did not save the incident reports. USACE employees should be queried to determine if someone else has saved these valuable records. 


\section{Appendix A: LPMS Reason Codes}

\begin{tabular}{|c|c|c|}
\hline \multirow[t]{7}{*}{1} & \multicolumn{2}{|c|}{ Weather Conditions } \\
\hline & A & Fog \\
\hline & B & Rain \\
\hline & c & Sleet or Hail \\
\hline & $\mathrm{D}$ & Snow \\
\hline & $\mathrm{E}$ & Wind \\
\hline & $\mathrm{F}$ & Lightning \\
\hline \multirow[t]{7}{*}{2} & \multicolumn{2}{|c|}{ Surface Conditions } \\
\hline & G & Low Water \\
\hline & $\mathrm{H}$ & Ice on or around tow \\
\hline & I & River current or Outdraft condition \\
\hline & J & Flood \\
\hline & $\mathrm{N}$ & Operations (run-spill-divert water, flush seals-reserve etc.) \\
\hline & 0 & Debris \\
\hline \multirow[t]{5}{*}{3} & \multicolumn{2}{|c|}{ Tow Conditions } \\
\hline & K & Interference by other vessel(s) \\
\hline & L & Tow malfunction or breakdown \\
\hline & M & Tow staff occupied with other duties \\
\hline & $P$ & Tow accident or collision \\
\hline \multirow[t]{10}{*}{4} & \multicolumn{2}{|c|}{ Lock Conditions } \\
\hline & AA & Accident or collision in lock \\
\hline & BB & Closed (unmanned shift) \\
\hline & $\mathrm{EE}$ & Repairing lock or lock hardware \\
\hline & Q & Debris in lock recess or lock chamber \\
\hline & $\mathrm{R}$ & Lock hardware or equipment malfunction \\
\hline & S & Lock staff occupied with other duties \\
\hline & $\mathrm{T}$ & Maintaining lock or lock equipment \\
\hline & U & Ice on lock or lock equipment \\
\hline & $\mathrm{Y}(\mathrm{y})$ & Inspection or testing lock \\
\hline \multirow[t]{9}{*}{5} & \multicolumn{2}{|c|}{ Other Conditions } \\
\hline & $\mathrm{CC}$ & Grounding \\
\hline & $\mathrm{DD}$ & Environmental (i.e. fish, animals, oil spills, etc.) \\
\hline & $\mathrm{FF}$ & Lock OK; Unused for other reasons (i.e. River closing etc.) \\
\hline & GG & Bye Time (reconnecting double lockage tows \\
\hline & $\mathrm{V}$ & Tow detained by Coast Guard or Corps \\
\hline & W & Collision or Accident \\
\hline & $x$ & Bridge or other structure (i.e. railway, pontoon, swing etc.) \\
\hline & Z & Other \\
\hline \multirow[t]{2}{*}{6} & \multicolumn{2}{|c|}{ Unknown } \\
\hline & UN & Unknown \\
\hline
\end{tabular}


THIS PAGE INTENTIONALLY LEFT BLANK 


\section{Appendix B: LPMS Closure Data}




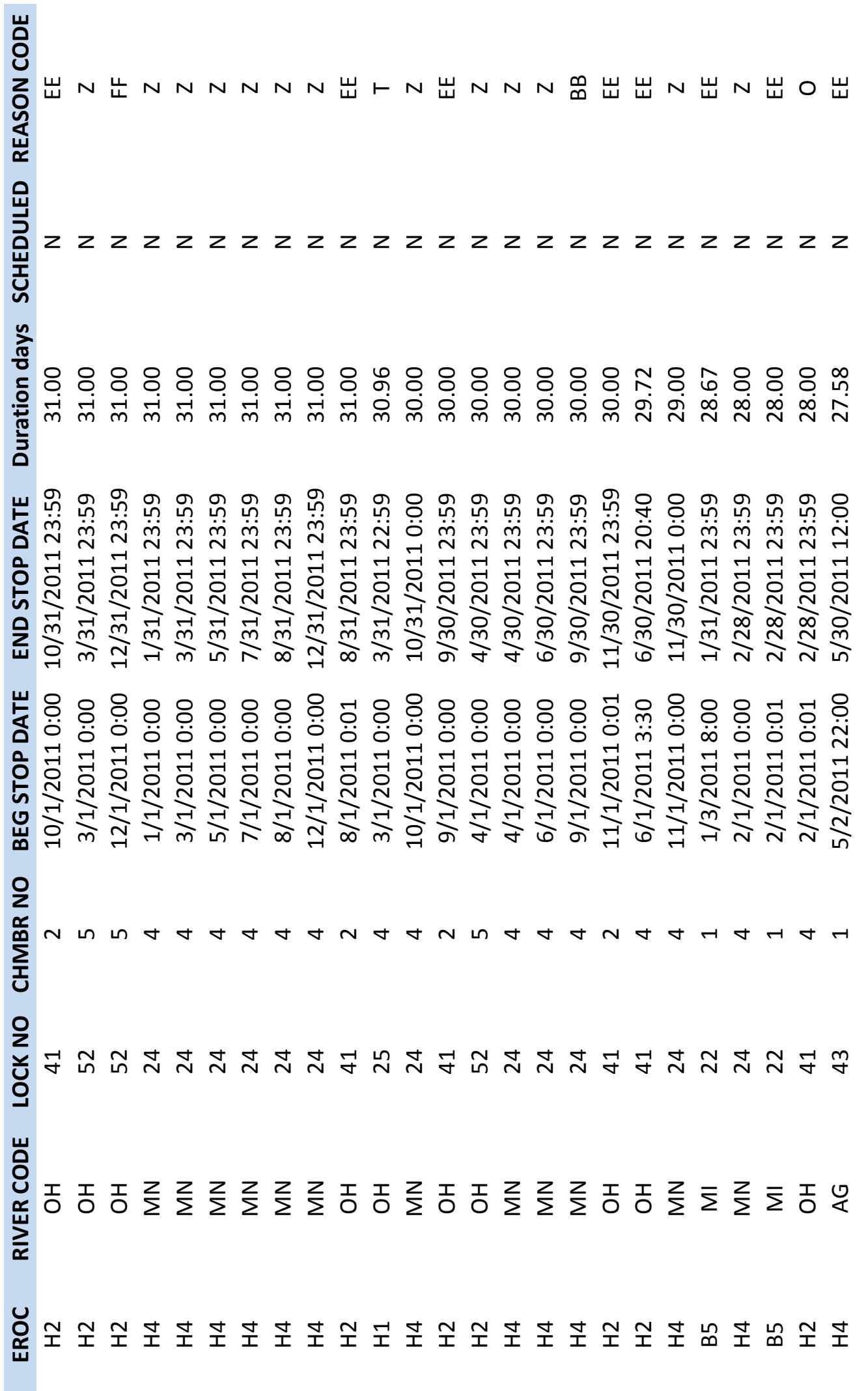




\section{Appendix C: FEM Failure Reporting Picklists}

\section{C.1 Failure classes}

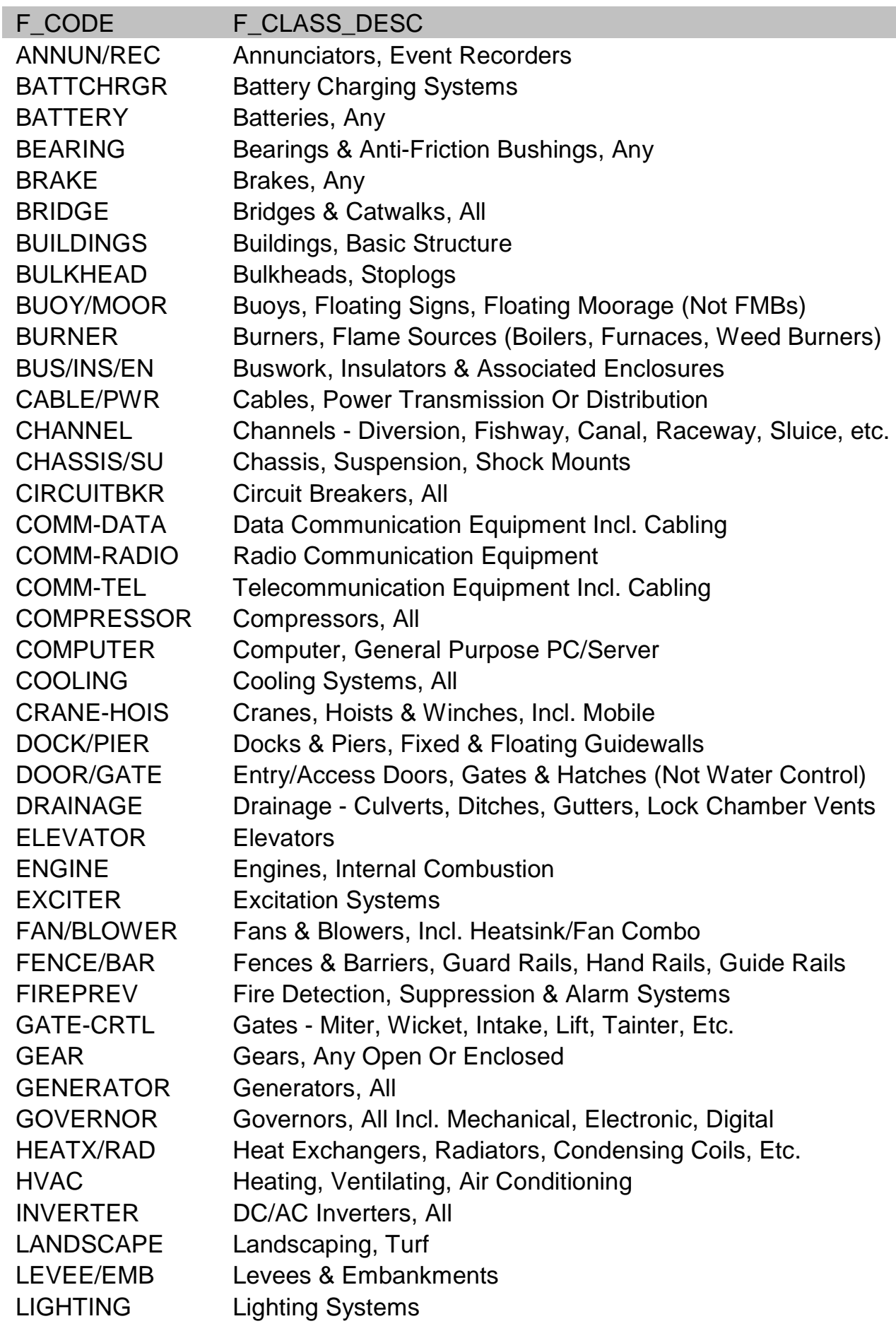




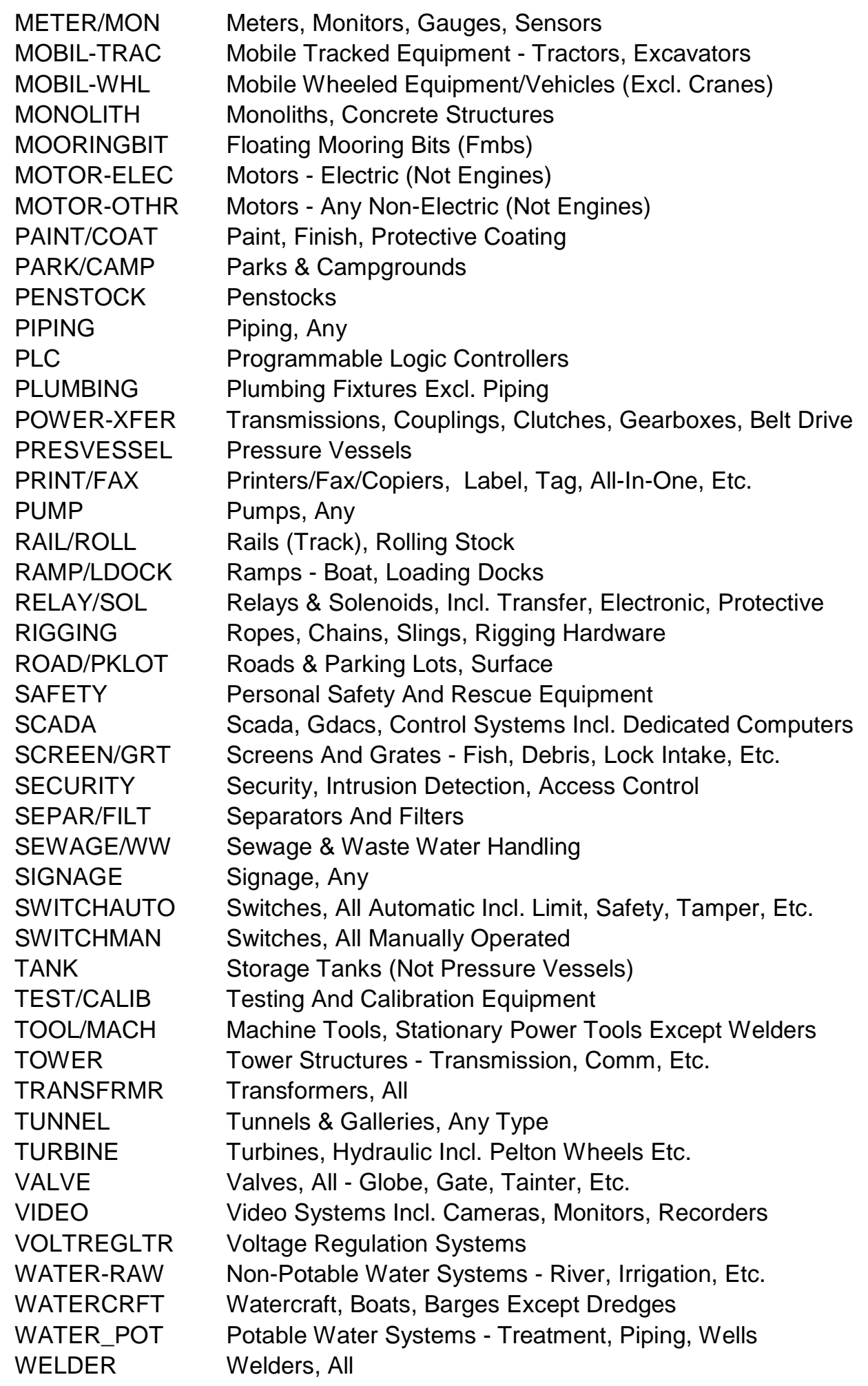




\section{C.2 Problems}

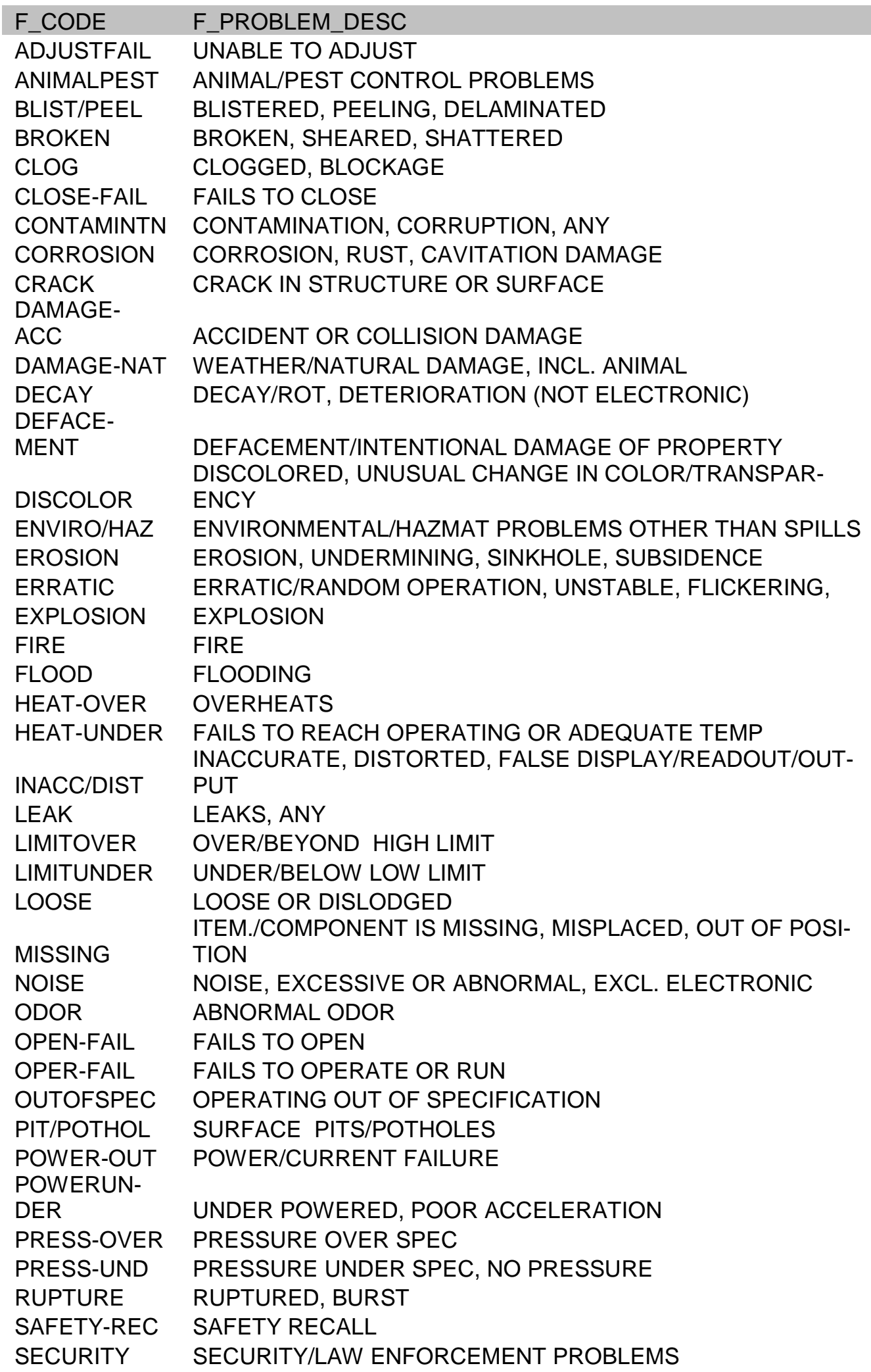




$\begin{array}{ll}\text { SEIZE/LOCK } & \text { SEIZED, LOCKED UP, FROZEN } \\ \text { SIGNALFAIL } & \text { NO OR POOR SIGNAL/TONE, POOR S/N RATIO } \\ \text { SINKIAWASH } & \text { SINKING, SUNK, AWASH, LOSS OF BOUYANCY } \\ \text { SMOKE/BURN } & \text { SMOKE, SCORCH MARKS, EVIDENCE OF BURNING } \\ \text { SPEEDOVER } & \text { TOO MANY RPMS OR CYCLES, TOO FAST } \\ \text { SPEEDUN- } & \\ \text { DER } & \text { TOO FEW RPMS OR CYCLES, TOO SLOW } \\ \text { SPILLENVIR } & \text { SPILL, OVERFLOW, ENVIRO/HAZMAT ISSUE } \\ \text { SPILLOTHER } & \text { SPILL, OVERFLOW, NOT ENVIRO/HAZMAT ISSUE } \\ \text { STALL/MISS } & \text { STALLS OR MISSES, HESITATES } \\ \text { START-ABNL } & \text { ABNORMAL OR UNEXPLAINED START } \\ \text { START-FAIL } & \text { WILL NOT START } \\ \text { STOP-ABNL } & \text { ABNORMAL OR UNEXPLAINED STOP, BREAKDOWN } \\ \text { STOP-FAIL } & \text { WILL NOT STOP OR SHUTDOWN } \\ \text { TENSION } & \text { TENSION TOO HIGH OR TOO LOW } \\ \text { VIBRATION } & \text { VIBRATION, EXCESSIVE OR ABNORMAL } \\ \text { WARNING } & \text { WARNING SIGNAL FROM A MONITORING DEVICE }\end{array}$

\section{C.3 Causes}

\begin{tabular}{|c|c|}
\hline F_CODE & F_CAUSE_DESC \\
\hline ACCIDENT & ACCIDENT OR COLLISION \\
\hline ADJUST-IMP & $\begin{array}{l}\text { ADJUSTMENT IMPROPER, MISCONFIGURED, MISALIGNED, } \\
\text { ETC. }\end{array}$ \\
\hline ANIMALPEST & ANIMAL/PEST CONTROL PROBLEMS \\
\hline ARCING & ARCING, ARCED \\
\hline BATTERY & BATTERY LOW OR FAILED \\
\hline BRITL/FATG & BRITTLE, CRYSTALIZED, FATIGUED \\
\hline CALIBRATN & CALIBRATION INCORRECT \\
\hline CAVITATION & CAVITATION \\
\hline CIRCTBRD & ELECTRONIC CIRCUIT BOARD FAILURE \\
\hline CLOG & CLOGGED, BLOCKAGE \\
\hline CONDENSATN & CONDENSATION \\
\hline COOLANT & COOLANT LEVEL OVER/UNDER, FAILED, LEAKED \\
\hline CORROSION & CORROSION, RUST \\
\hline CRACKED & CRACKED COMPONENT \\
\hline DEBRIS & DEBRIS ACCUMULATION OR DAMAGE \\
\hline DEFECTIVE & DEFECT, MANUFACTURING OR CONSTRUCTION \\
\hline DIRTY & DIRTY \\
\hline FASTENER & FASTENER/PIN/LOCKNUT/RIVET/RETAINER ETC. FAILED \\
\hline FOROBJDAMG & FOREIGN OBJECT DAMAGE (FOD) \\
\hline GROUND-EL & ELECTRICAL GROUNDING FAILED, FLOATING GROUND ETC. \\
\hline HOLE/PERF & HOLED, PERFORATED, TORN, PIERCED \\
\hline HUMAN/OPER & HUMAN/OPERATOR ERROR \\
\hline INSTALLTN & INSTALLED/APPLIED/MOUNTED INCORRECTLY \\
\hline JAM/BIND & $\begin{array}{l}\text { JAMMED, WEDGED, BOUND UP, KINKED, TANGLED, PINCHED } \\
\text { LIMITING DEVICE/SWITCH/RELIEF VALVE FAILED/MISOPER- }\end{array}$ \\
\hline LIMIT-DEV & ATED \\
\hline LOOSE & LOOSE OR DISLODGED \\
\hline LUBRICATN & LUBRICATION - OVER, UNDER, FAILED, LEAKED \\
\hline
\end{tabular}




$\begin{array}{ll} & \text { ITEM/COMPONENT IS MISSING, MISPLACED, OUT OF POSI- } \\ \text { MISSING } & \text { TION } \\ \text { OVERLOAD } & \text { LOADED BEYOND CAPACITY OR RATING } \\ & \text { OVER TIGHTENED, OVER TORQUED, INSUFFICIENT } \\ \text { OVERTIGHT } & \text { SLACK/GIVE } \\ \text { POWER-OUT } & \text { POWER/CURRENT FAILURE } \\ \text { PRESS-OVER } & \text { PRESSURE OVER SPEC } \\ \text { PRESS-UND } & \text { PRESSURE UNDER SPEC, NO PRESSURE } \\ \text { SEAL/GASK } & \text { SEAL OR GASKET FAILURE } \\ \text { SHORT-CIRC } & \text { SHORT CIRCUIT, INCL SHORT TO GROUND, RESULTING TRIP } \\ \text { SOFTWARE } & \text { SOFTWARE/FIRMWARE FAILURES, CORRUPTION, ETC. } \\ \text { STATIC/EMF } & \text { STATIC ELECTRICITY, EMF EFFECTS } \\ \text { STRIPPED } & \text { STRIPPED THREADS OR LUGS } \\ \text { UNKNOWN } & \text { UNKNOWN, UNEXPLAINED, NO DIAGNOSIS } \\ \text { VAND/THEFT } & \text { VANDALISM, SABOTAGE, ARSON, THEFT } \\ \text { WATER-LEVL } & \text { UNUSUAL CHANGE IN WATER LEVEL } \\ \text { WEAR-EXCSV } & \text { WEAR - EXCESSIVE } \\ \text { WEAR-NRML } & \text { WEAR - NORMAL, WORN OUT FROM NORMAL USE/AGEING } \\ \text { WEATHER } & \text { WEATHER - LIGHTNING, WIND, RAIN, ICING, ETC. }\end{array}$

\section{C.4 Remedies}

$\begin{array}{ll}\text { F_CODE } & \text { F_REMEDY_DESC } \\ \text { RE- } & \text { REPLACED PART OR SUB-COMPONENT } \\ \text { PLACEPRT } & \text { REPAIRED - INCL. CLEANED } \\ \text { REPAIR } & \text { REPLACED ENTIRE UNIT } \\ \text { REPLACEALL } & \text { MANUFACTURED/FABRICATED REPAIR PART LOCALLY } \\ \text { MANUF/FABR } & \text { RUN TO FAILURE } \\ \text { RTF } & \text { OVERHAULED UNIT OR COMPONENT } \\ \text { OVERHAUL } & \text { NO ACTION TAKEN OR REQUIRED } \\ \text { NO_ACTION } & \text { ADJUSTED, REFILLED, DRAINED, ALIGNED, CALIBRATED, ETC. } \\ \text { ADJUST } & \text { SERVICED BY EXTERNAL PROVIDER, ON OR OFF-SITE } \\ \text { SERVICE-XT } & \\ \text { PM-AD- } & \text { PM SCHEDULE ADVANCED TO RESOLVE THE PROBLEM } \\ \text { VANCD } & \text { REMOVED - NO LONGER NEEDED } \\ \text { REMOVE } & \text { REPAIRED/REPLACED PART OR ALL PER SAFETY RECALL/NO- } \\ \text { SAFETYREP } & \text { TICE }\end{array}$


THIS PAGE INTENTIONALLY LEFT BLANK 


\section{Appendix D: Emergency Closures 1999-2005}




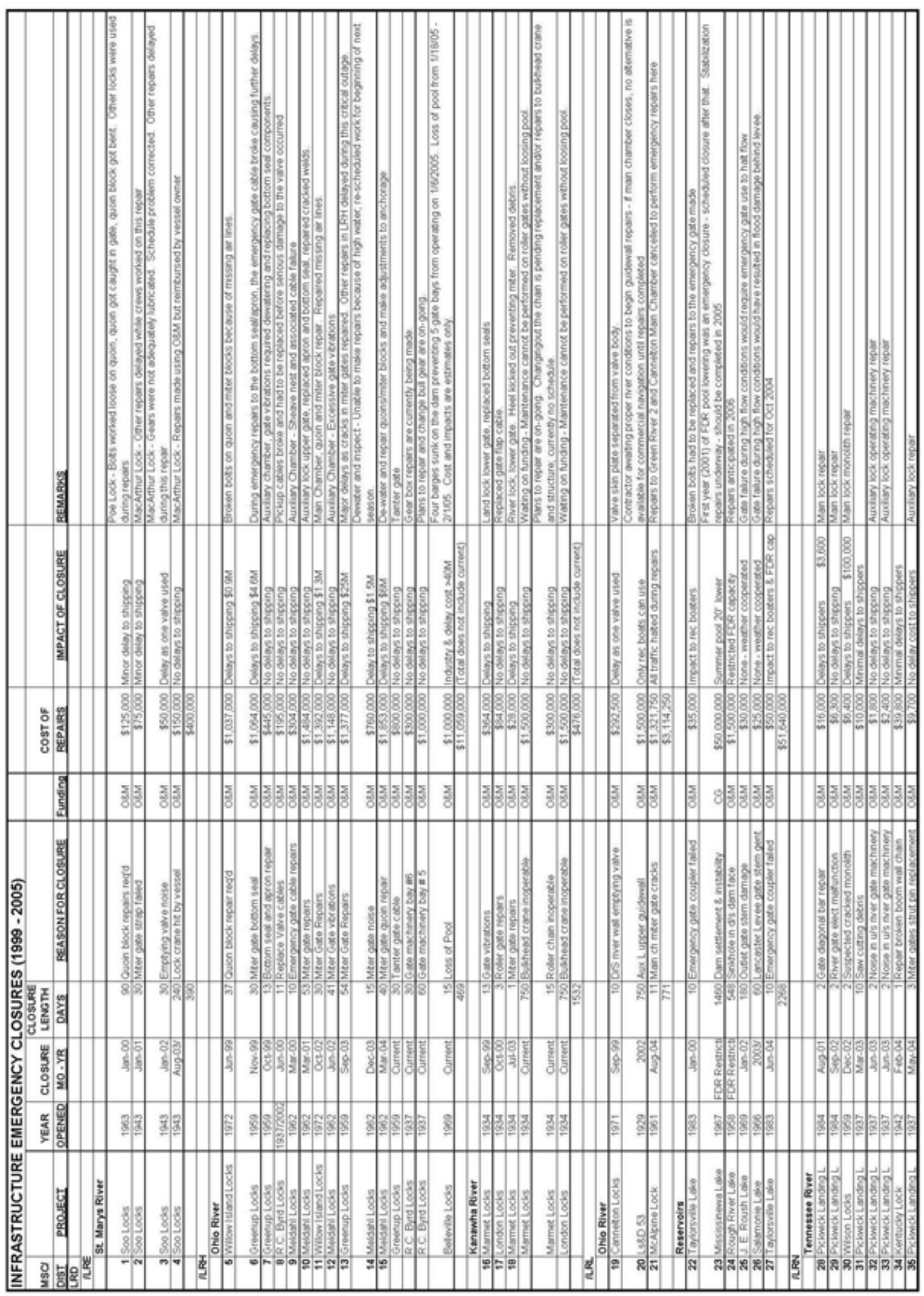




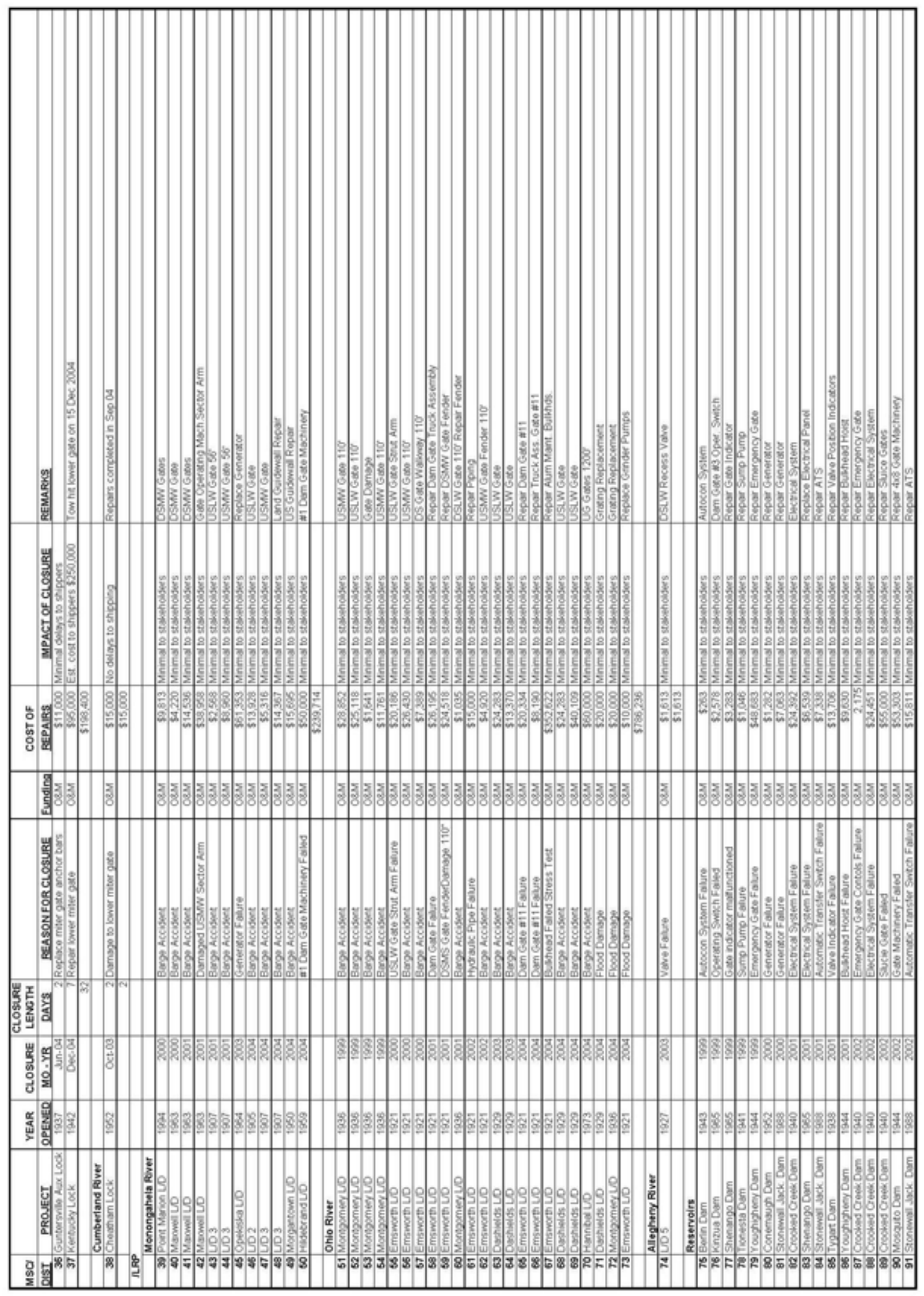




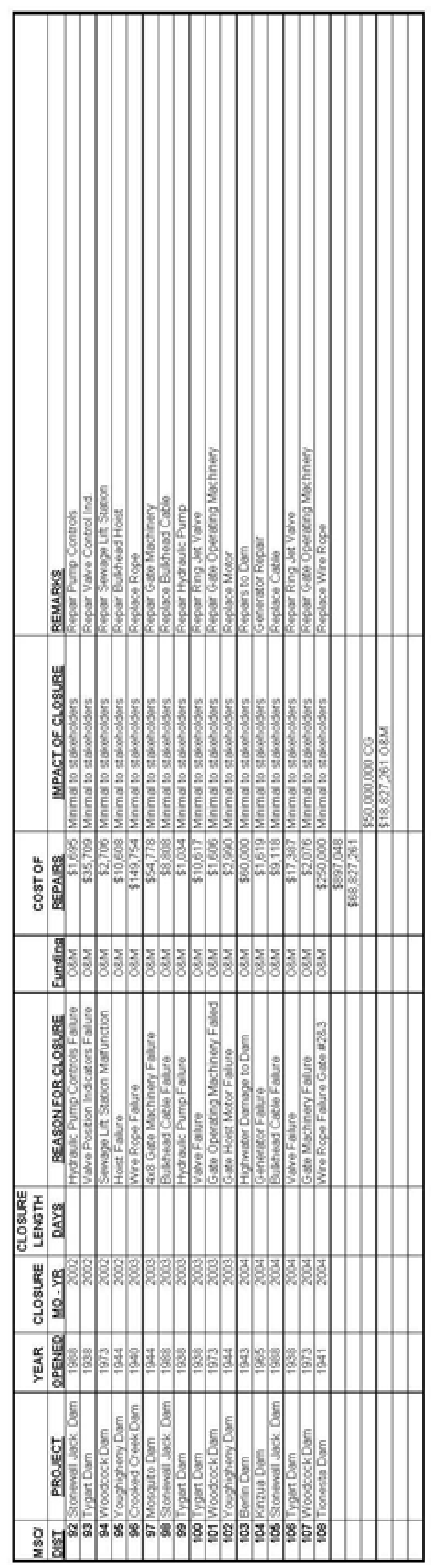




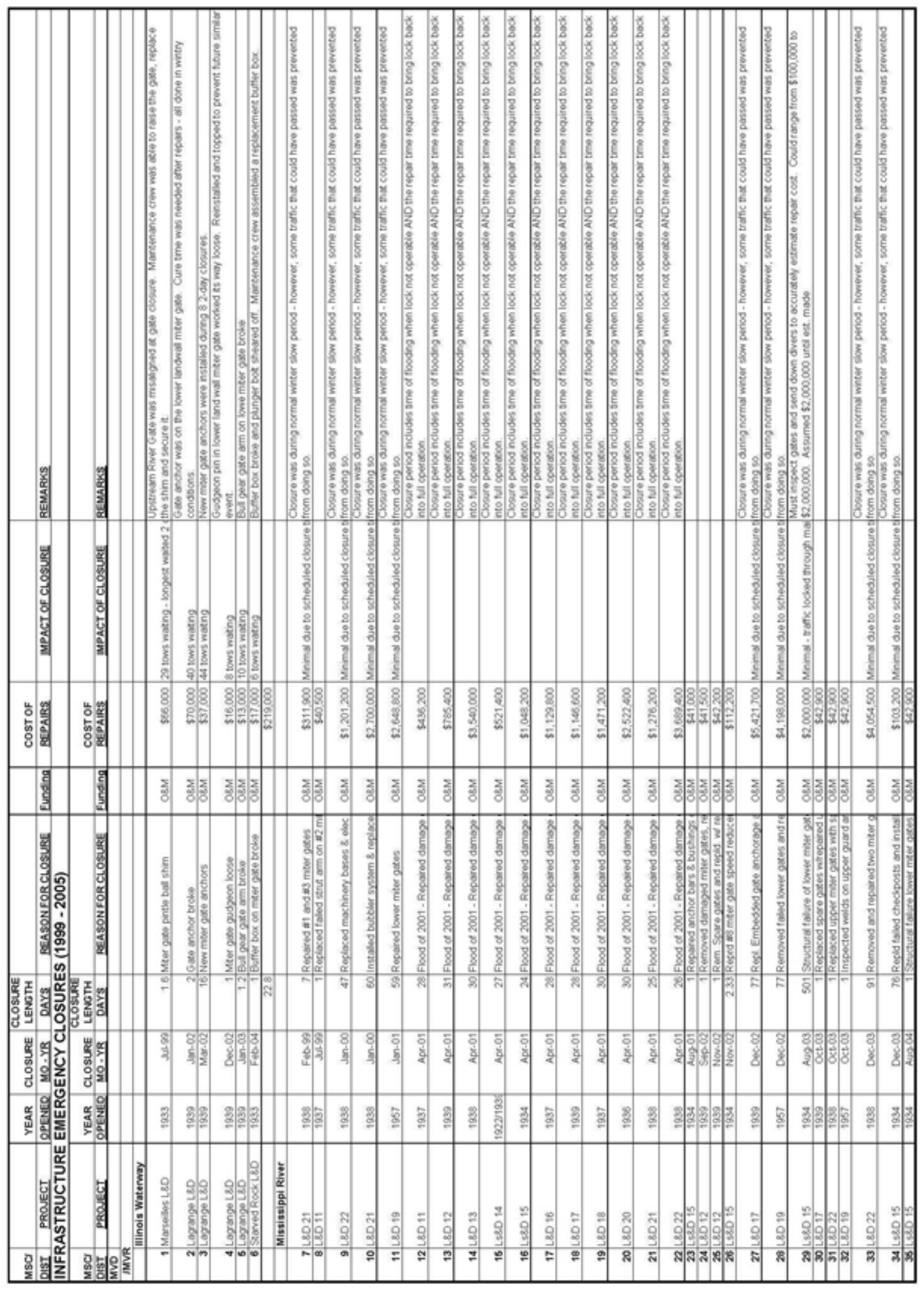




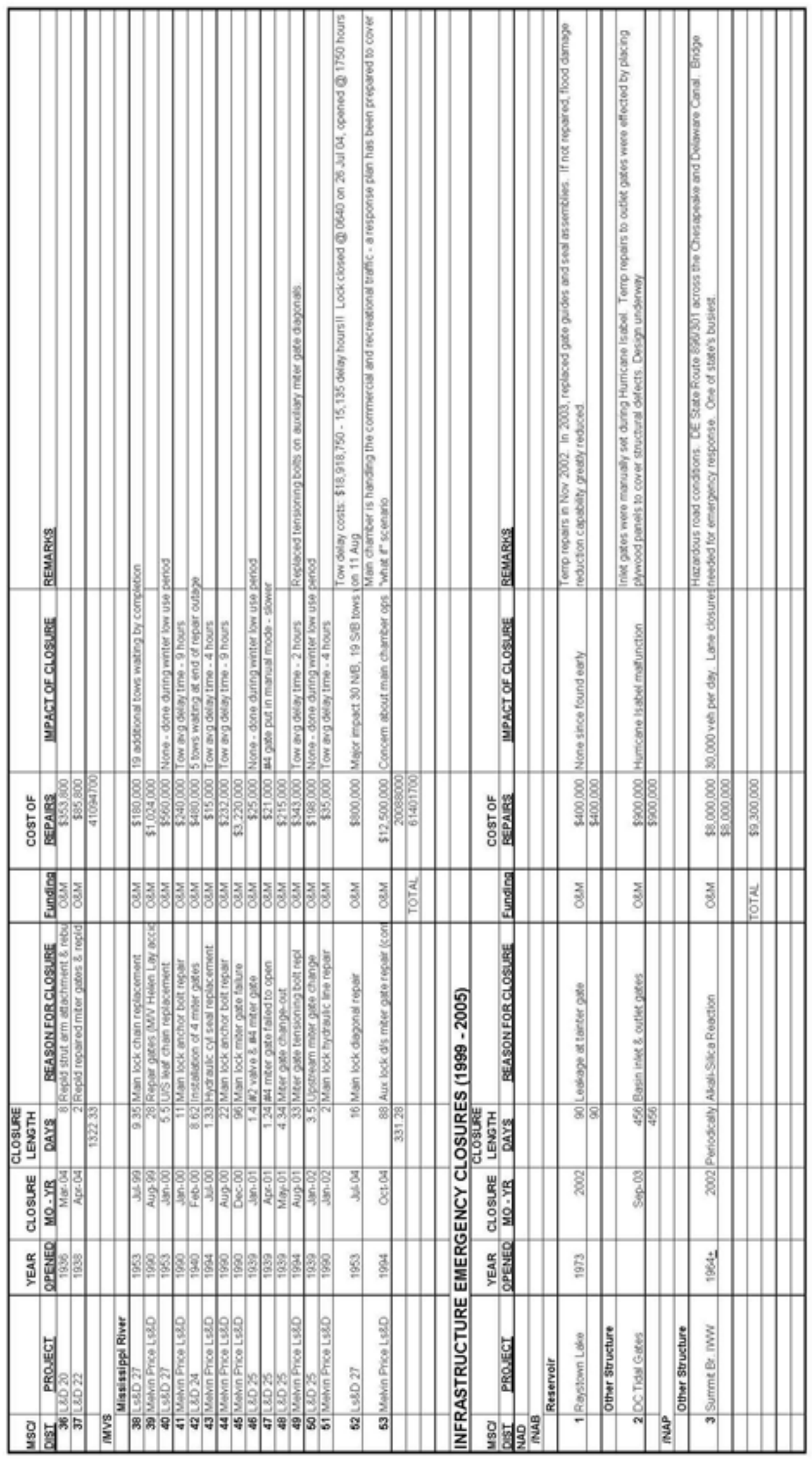




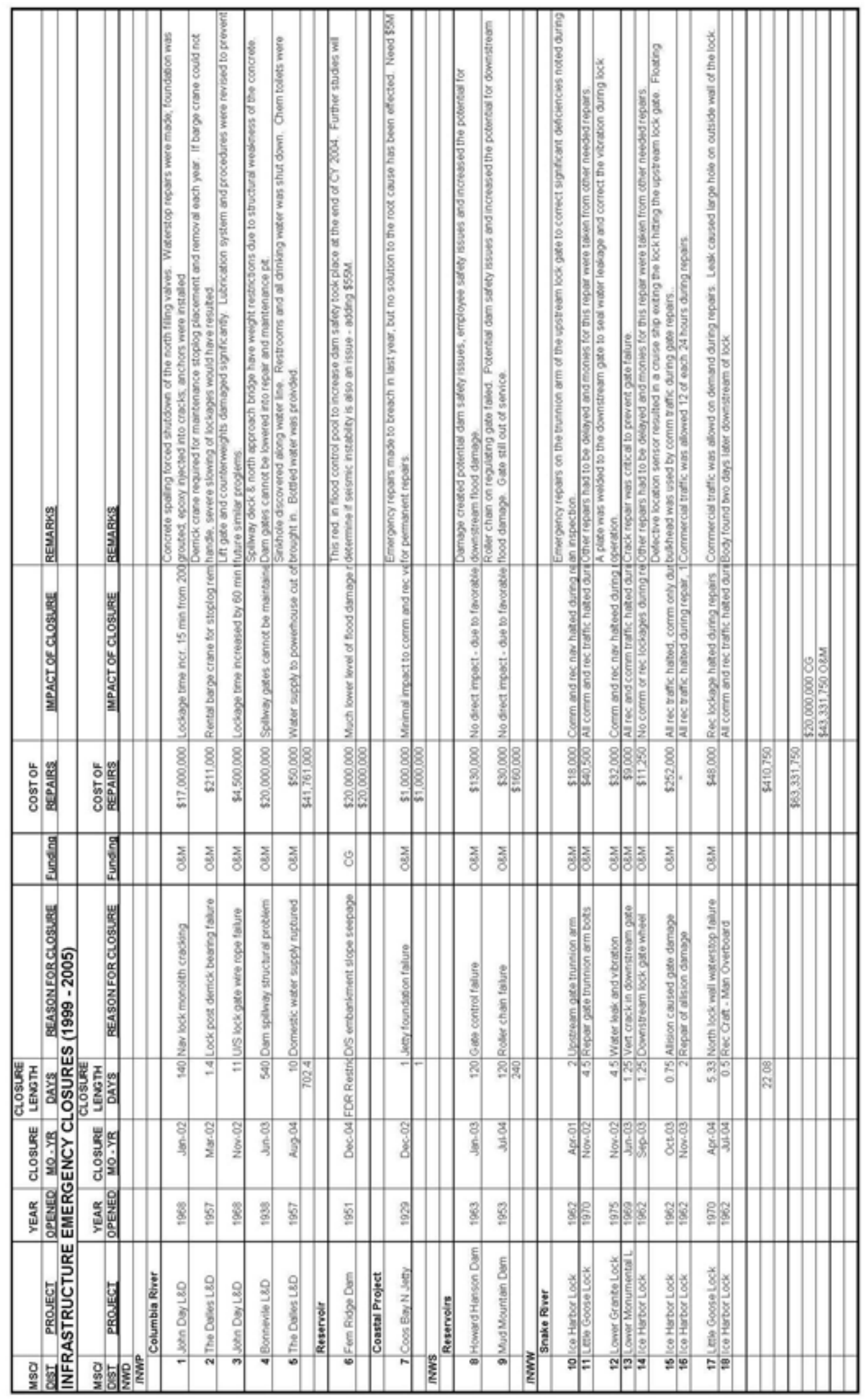




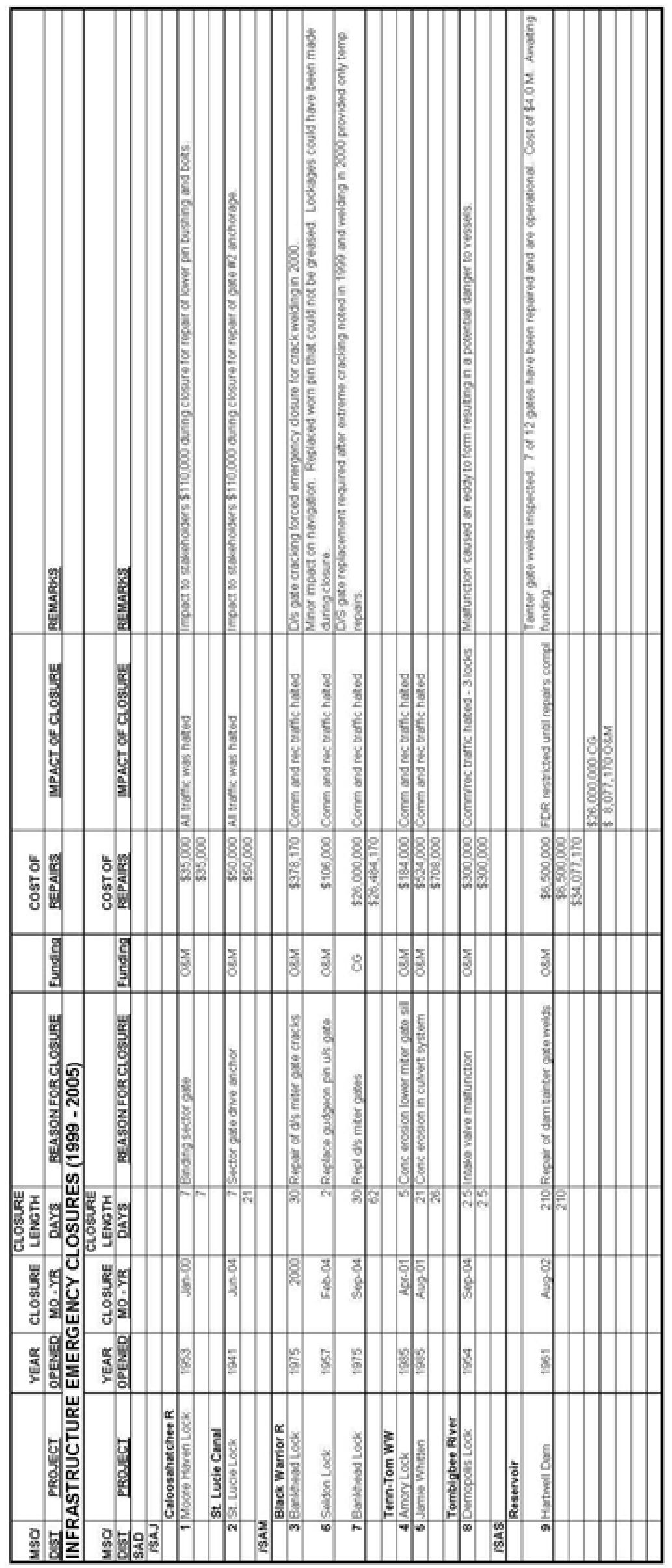




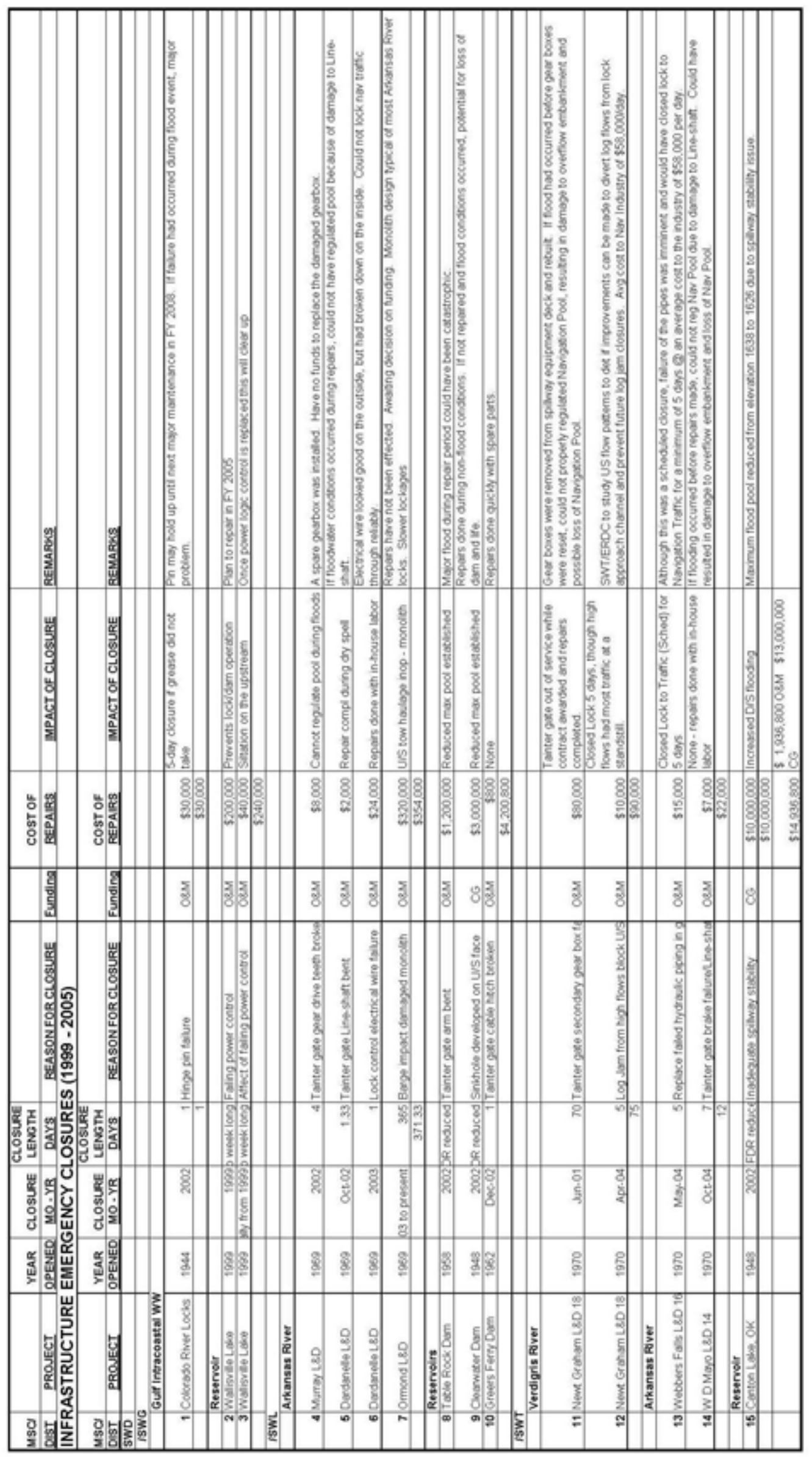




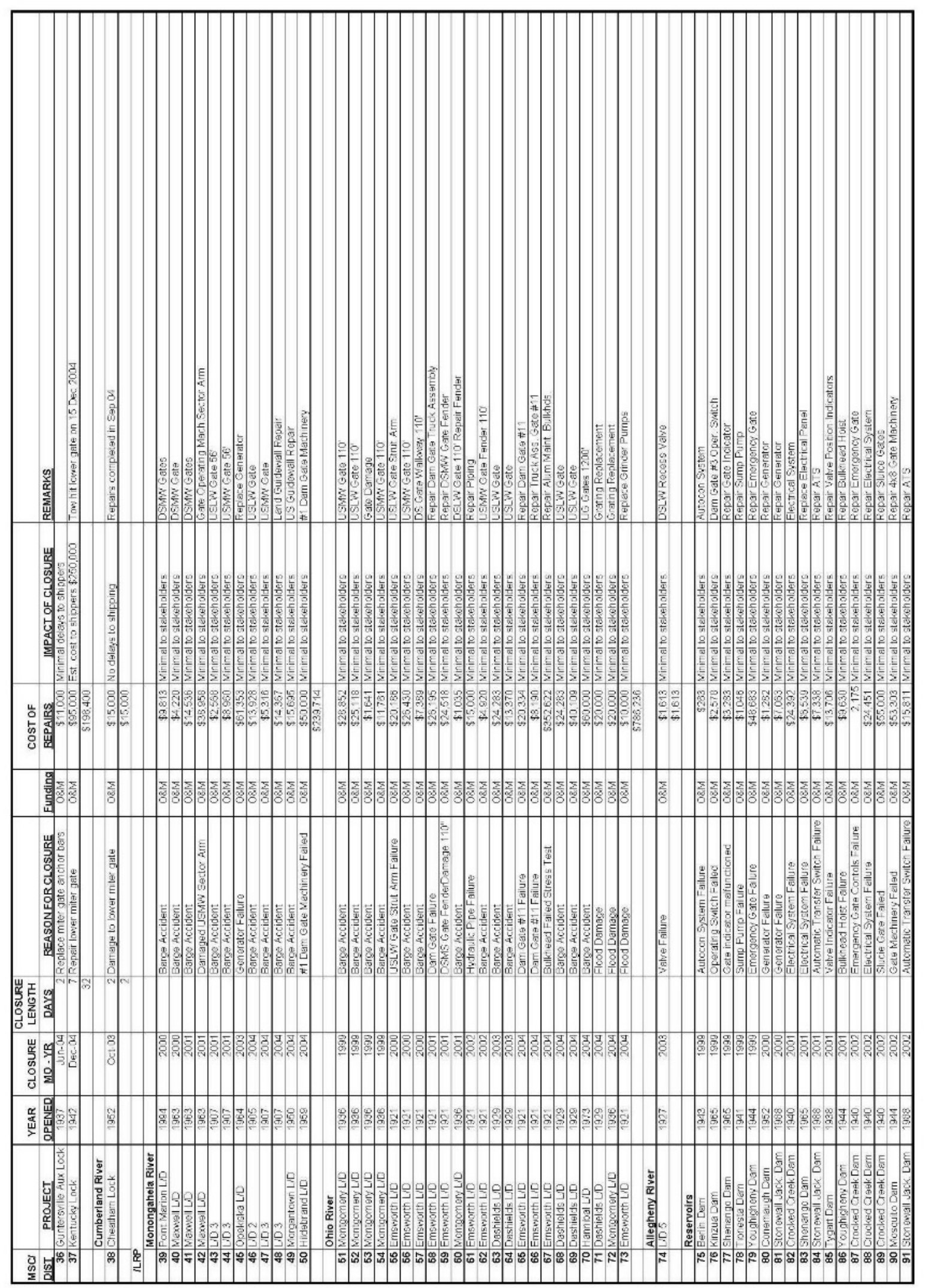




\section{Appendix E: Incident Reports}

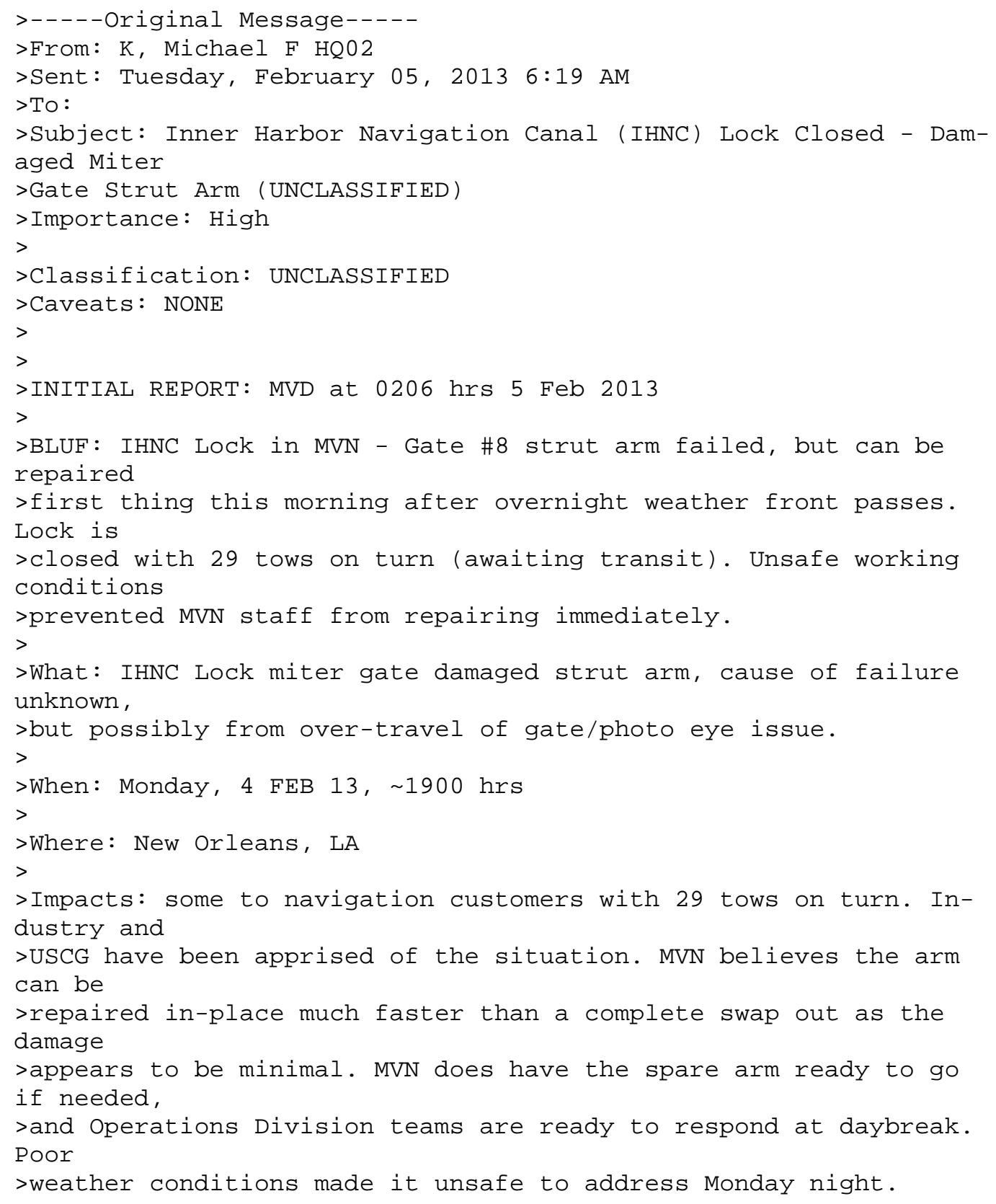




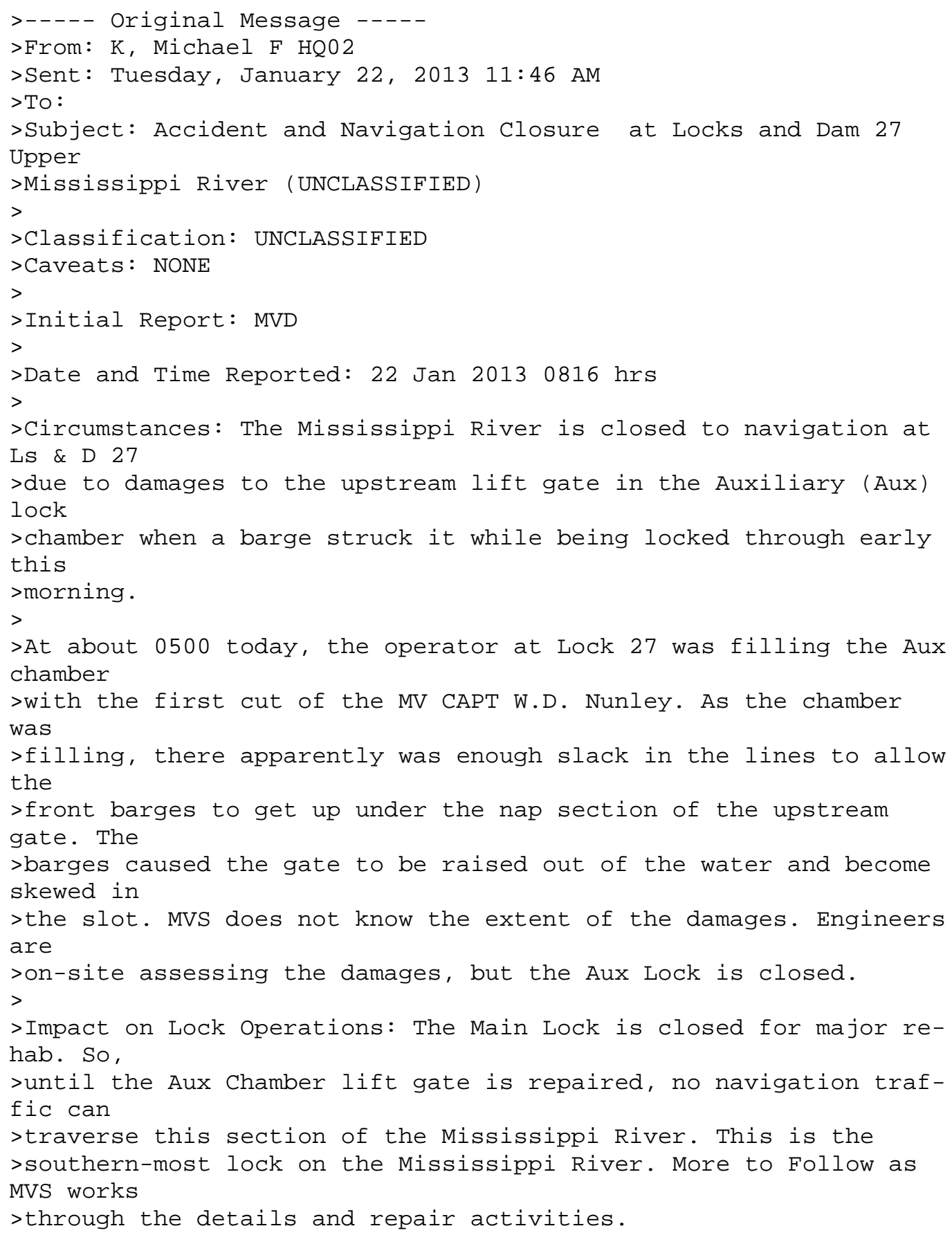




\section{Appendix F: Navigation Notices}

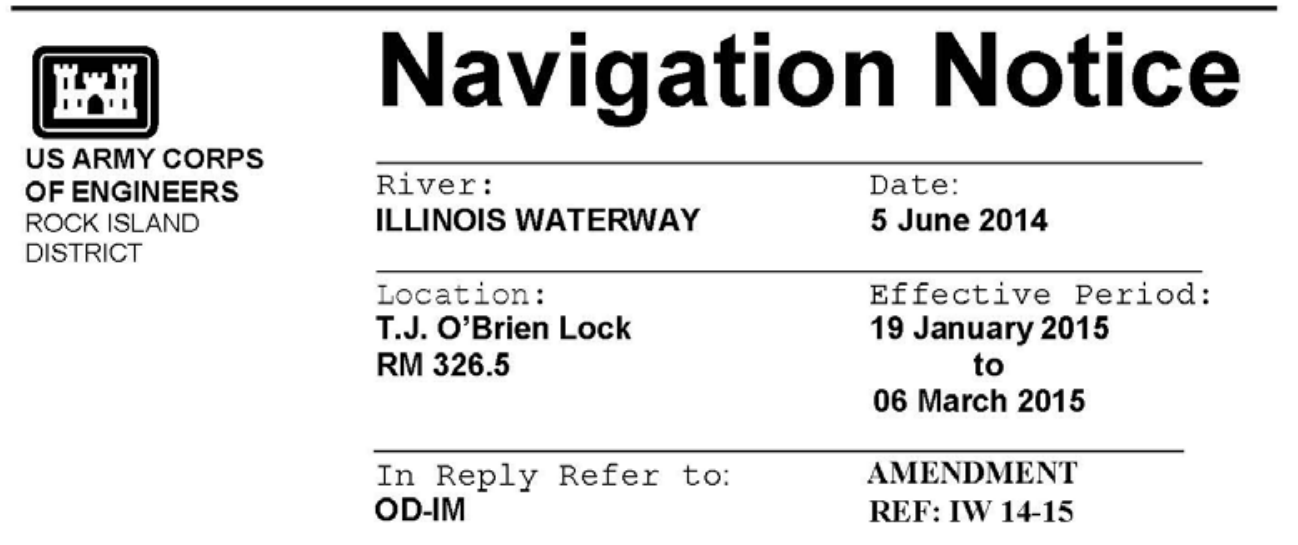

AMENDMENT

AMENDMENT

AMENDMENT

AMENDMENT

ILLINOIS WATERWAY

LOCK CLOSURE

T.J. O’Brien Lock \& Dam, RM 326.5

T.J. O'Brien Lock \& Dam, RM 326.5 will close 47 Days, 0700 hrs on Monday, 19 January 2015 to 1730 hrs on Friday, 6 March 2015 to perform major

maintenance on the upper sector gates. Lock dewatering is required to perform activities.

Mariners are requested not to tie up along the guide walls during this period.

Please contact T.J. O'Brien Lock and Dam, Channel 16 or (773) 646-2183 for further instructions.

IISII

Andrew Barnett, Chief

Illinois Waterway Maintenance Section

IW 14-19 


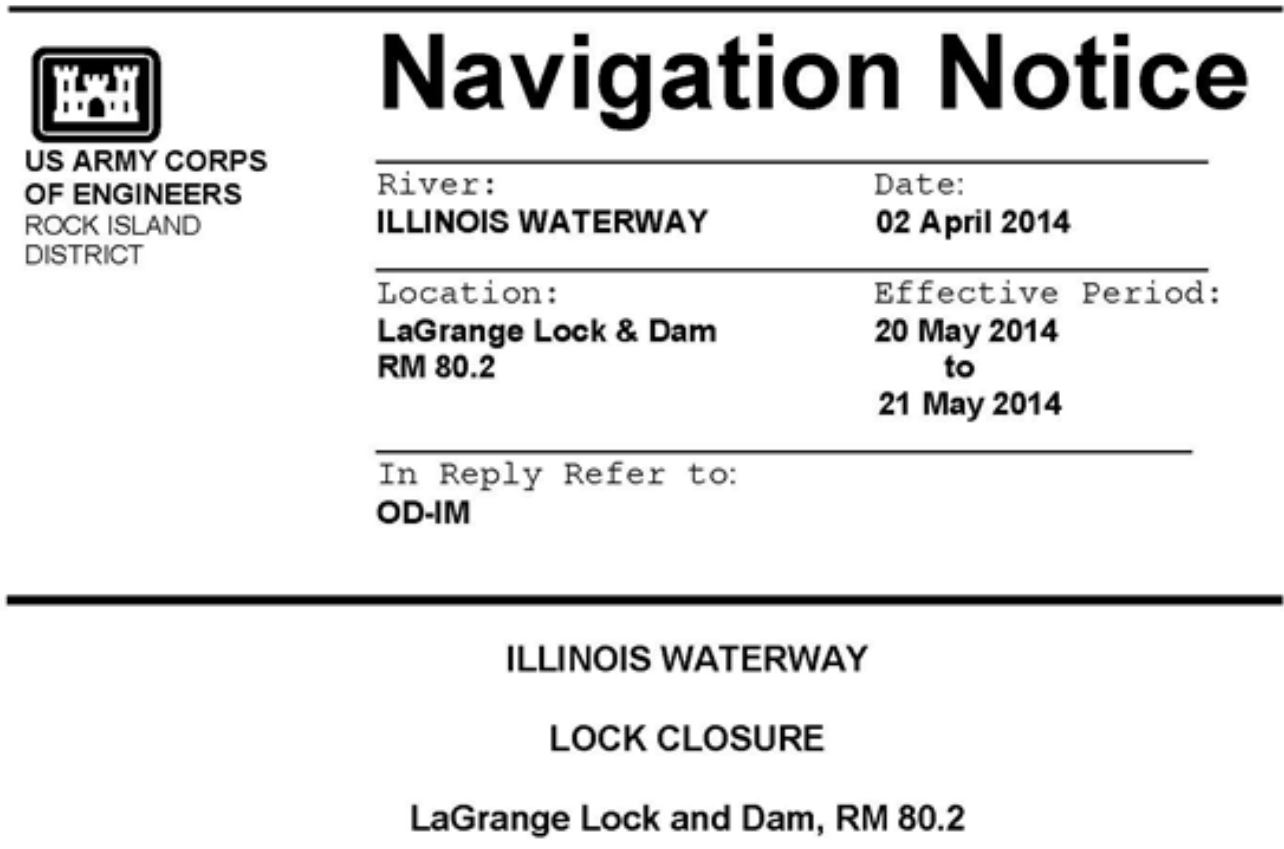

LaGrange Lock \& Dam, RM 80.2 will close 36 hrs, 0600 on Tuesday, 20 May 2014 to $1800 \mathrm{hrs}$ on Wednesday, 21 May 2014 to perform maintenance on miter gate machinery.

Mariners are requested not to tie up along the guide walls during this period.

Please contact LaGrange Lock and Dam, Channel 14 or (217) 225-3317 for further instructions.

IIS/I

Andrew Barnett, Chief

Illinois Waterway Maintenance Section

IW 14-10 


\section{IrwI}

in'

US Army Corps

of Engineers

Jacksonville District

Date: 08/25/2014

US ARMY CORPS OF ENGINEERS

JACKSONVILLE DISTRICT

ATTN: CESAJ-OD-SN

PO BOX 4970

JACKSONVILLE, FL 32232-0019

904-232-3187

POC: http://www.saj.usace.army.mil/Missions/CivilWorks/Navigation/NoticestoNavigation.aspx
NOTICE TO NAVIGATION INTRESTS

\author{
NOTICE NUMBER: 004 \\ LOCAL NUMBER: 201408025 \\ WATERWAY: CANAVERAL HARBOR LOCK \\ EFFECTIVE: 08/25/2014 00:00 thru 9/17/2014 24:00 EST
}

\title{
REVISED CANAVERAL LOCK \\ $40^{\prime}$ WIDTH RESTRICTION
}

REFERANCES:

a. 33 CFR Navigation and Navigable Waters

b. No. 20140604, dated 4 June 2014, SUBJECT; CANAVERAL LOCK 45 FOOT WIDTH RESTICTION.

c. No. 20140805, dated 5 August 2014, SUBJECT; CANAVERAL LOCK 45 FOOT WIDTH RESTICTION.

\section{Notice to Navigation}

Notice is given that Canaveral Lock will be conducting gate repairs 25 August to 17 September 2014. Before and during scheduled repairs Canaveral lock cperations will be restricted to vessels 40 feet wide or less. Vessels greater than 40 feet wide will not be allowed lock passage. For up to date Canaveral Lock operational information contact the shift operator at 312-783-5421 between 0600-2130.

\author{
//signed// \\ MULAANSCAPLMA MPYN.1091240960 \\ Chief Navigation \& \\ Flood Risk Management \\ South Florida Operations
}




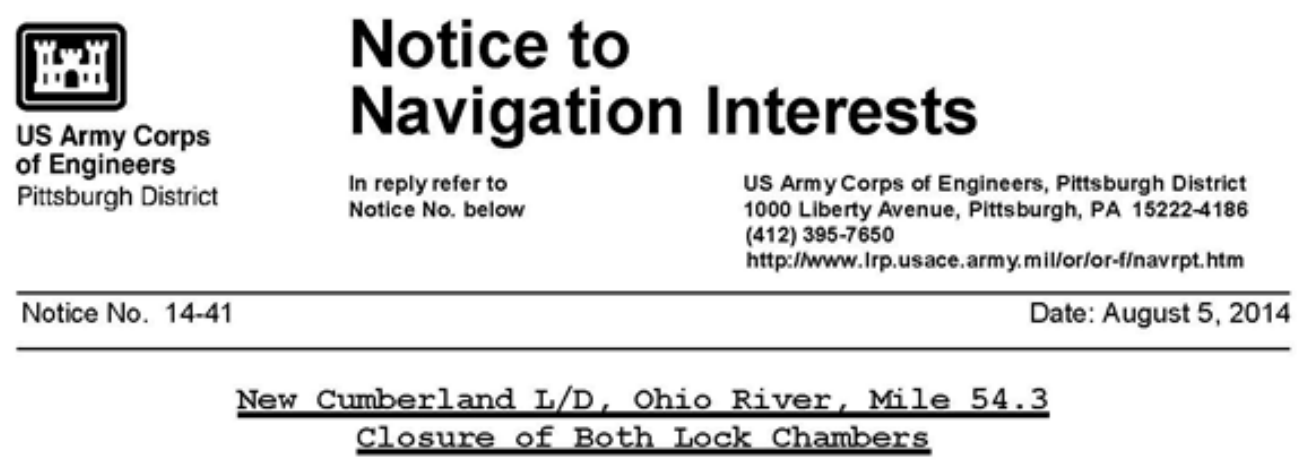

1. To All Whom It May Concern: Notice is given that the U.S. Army Corps of Engineers will close both lock chambers on Thursday August 7, 2014 at New Cumberland Lock and Dam Ohio River, Mile 54.3.

2. The 110-ft $\times 1,200-f t$ Primary Lock Chamber and the 110-ft $x$ 600-ft Auxiliary Lock Chamber will be closed from 8:00 AM until 12:00 PM. During this four (4) hour outage New Cumberland Lock and Dam will be closed to all navigation traffic.

3. Minimal delays to navigation traffic can be expected.

FOR THE DISTRICT ENGINEER: 


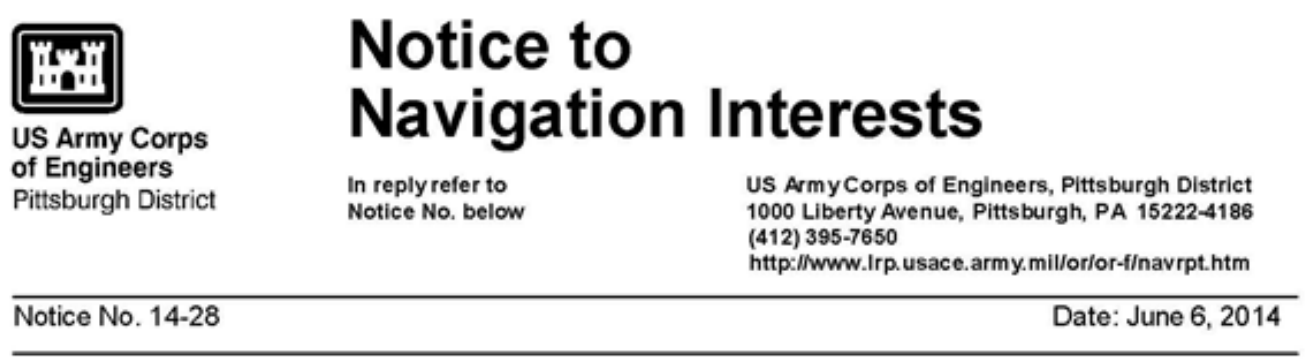

Lock and Dam 3, Mononqahela River, Mile 23.8 Closure of the 56-ft $\times 720$-ft Land Lock Chamber

1. To All Whom It May Concern: Notice is given that the U.S. Army Corps of Engineers will close the $56-\mathrm{ft}$ x $720-\mathrm{ft}$ land lock chamber at Lock 3, Monongahela River to weld the flume way beam in preparation of the work being performed on the emptying valves, the miter sills, and the downstream landwall miter gate. The work will be take place during daylight hours staring Monday June 9, 2014 and ending Friday June 13, 2014.

2. The 56-ft $\times 720-\mathrm{ft}$ land lock chamber will be closed to all river traffic from 7:30 A.M. until 4:00 P.M. during this work period.

3. The 56-ft $\times$ 751-ft extended river chamber will be open to navigation during this closure. Minimal delays to navigation can be expected.

4. Navigators are requested to use extreme caution when entering or leaving the river chamber during this closure of the land chamber to prevent a complete shutdown of navigation.

FOR THE DISTRICT ENGINEER:

$\backslash \backslash \mathrm{SIGNED} / /$

Richard C. Lockwood

Chief, Operations Division 


\section{Notice to US Army Corps of Engineers \\ Pittsburgh District Navigation Interests

Montgomery $L / D$, Ohio River, Mile 31.7 Closure of the $110-\mathrm{ft} \times 600-\mathrm{ft}$ Primary Lock Chamber

1. To All Whom It May Concern: Notice is given that the U.S. Army Corps of Engineers Repair Fleet will close the 110-ft x 600-ft primary lock chamber to perform repairs to the downstream miter gates, replace miter gate anchorages, replace hydraulic gate and valve cylinders, and install waterway safety signs. The repair work is scheduled to begin at 12:01 A.M. on September 8, 2014 and will be completed by 11:00 P.M. on 26 september, 2014 .

2. The 110-ft $\times$ 600-ft primary lock chamber at Montgomery L/D will be closed to all navigation during this work period and all navigation traffic will pass through the 56-ft $\times 360$-ft auxiliary lock chamber. Major delays to navigation are expected.

3. The Corps will institute the following lockage procedure which has been developed in cooperation with the Waterways Association of Pittsburgh. Boat locking order will be determined by arrival time at Montgomery $\mathrm{L} / \mathrm{D}$, all pilots should radio Montgomery $\mathrm{L} / \mathrm{D}$ at normal arrival points. All red flag barges in the tow must also be reported by the pilot during this radio call. No adding or swapping of barges will be allowed once the tow's lock turn has been established. All tows must be ready to lock when put on the waiting list. The lockages will be accomplished as a standard series of three tows in one direction. Because of approach conditions (outdrafts and short river guard walls), it is recommended that users limit their tow size to no more than a triple lockage. Under normal river conditions the Lockmaster will allow, if requested by the pilot when calling for position of the tow, a towboat to lock through with a maximum of five (5) lockages. In no case will the first or last tow in a series of 
CELRP-OP

Navigation Notice No. 14-18

three tows be more than a four (4) cut lockage unless only larger tows are in line. By following this procedure, there will be a minimal tow make-up and approach time when changing directions without a program of "self-help" by navigation interests, the Corps can only handle up to a triple lockage with its on-site tow haulage equipment.

4. To help eliminate some of the waiting time for towboats, an arriving tow can designate to be broken up into a maximum of three (3) separate tows. Each tow will then be locked in accordance with the procedure outlined in paragraph 3 above. The pilot of the large tow will have to notify Montgomery L/D of the intent to breakup into smaller tows and must provide the Lockmaster with the names of the other towboats designated to handle the other tows not later than six (6) hours before their lockage turn. If the designated towboat(s) are not available when called by Montgomery L/D, they will lose their turn and go to the end of the waiting line.

5. During the closure of the 110-ft x 600-ft primary lock chamber closure, tows should move to the closest mooring cell for staging prior to their lockage turn, rather than waiting at landings. Then it will be necessary for tows, under normal river conditions, to follow one another on the river guard wall when a series of lockages are being made in one direction. Each tow in the series should be aware of the tow that they follow and be on the river guard wall as soon as that tow enters the lock chamber. While this practice will speed up the lockage process, it is imperative that tows exercise extreme caution when encountering outdraft or backlash conditions.

6. In an effort to reduce delay time at the locks, a program of "self-help" by navigation interests is necessary. A "self-help" program will allow waiting towboats to assist tows out of the lock chamber. The Lockmaster will designate the helper boats as tows arrive for position. The second and third towboats in the first series of lockages in the opposite direction will be the designated helper boats unless conditions, equipment or cargo prevent the use of that towboat as a helper. Any tow with a tank barge must be accompanied at all times by a towboat. It will be necessary for all towboats to monitor their radios 24 hours a day.

7. Other specific procedures to facilitate lockage operations through the small chamber have been developed in cooperation with the towing industry. The corps is asking for everybody's 
CELRP-OP

Navigation Notice No. 14-18

cooperation and help in making the locking operations go as smoothly as possible during the closure of the large chamber.

a. All excess rigging will be removed prior to entering the lock chamber. Remaining rigging should be ready to be knocked loose after the cut is secured in the lock chamber.

b. On upbound tows, two locking lines, one head and one stern, must be available on each cut. On downbound tows, two locking lines, one head and one stern, must be available on each cut. Each line must be at least 75 feet long and $1-1 / 2$ " in diameter. To minimize locking time, all lines will stay with each cut. Lines will not be permitted to be carried from one cut to another.

c. Three deckhands are required during multiple lockages.

d. All multiple cut tows will be made up in designated staging areas, clear of the lock gates, so as not to interfere with lockage operations.

e. The Montgomery lock filling system may cause turbulence and surging of water while filling the small chamber. Deckhands need to be extra vigilant in tending lines to avoid an accident which could close the locks totally.

8. Towboats are cautioned to use minimal power when operating over the lower sill to avoid forcing debris onto the miter sill. This debris could prevent the miter gates from closing and require stoppage of navigation until the material is removed by dredging or diving operations.

9. If critical industrial shipments are essential to sustain continued operation, the affected companies should immediately contact the Waterways Association of Pittsburgh. They will review all requests for priority before submitting them to the Corps for our consideration. If it becomes necessary to prioritize lockages through the small chamber, the corps will make the final decision concerning lockage procedures as conditions and situations change. In accordance with standard Corps policy, the Lockmaster may also vary the locking procedure in an effort to equalize waiting times.

10. Information concerning lockages will be broadcast by radio on Channel $13(155.65 \mathrm{Mhz})$ and any towboat not answering a call

from the locks will be dropped to the end of the waiting list. 
CELRP-OP

Navigation Notice No. 14-18

11. All towboats are to stay with their tows while waiting for lockages unless designated to assist other tows through the small lock.

12. Recreation boaters are discouraged from locking through Montgomery L/D, Ohio River during the lock chamber closure. You will encounter extremely long delays since priority will be given to scheduled commercial passenger vessels and commercial tows.

13. Navigators are requested to use caution when entering or leaving the river lock chamber during this closure of the land chamber to prevent a complete shutdown of navigation.

FOR THE DISTRICT ENGINEER: 


\section{Appendix G: Maintenance Cards}

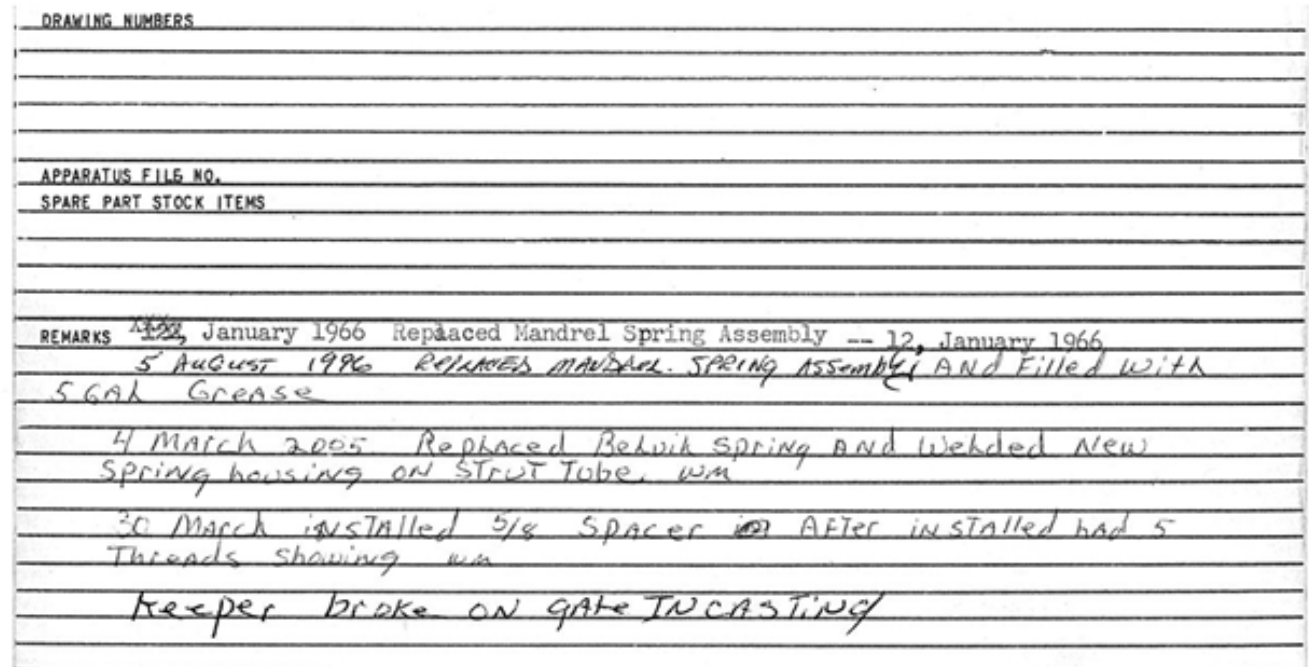

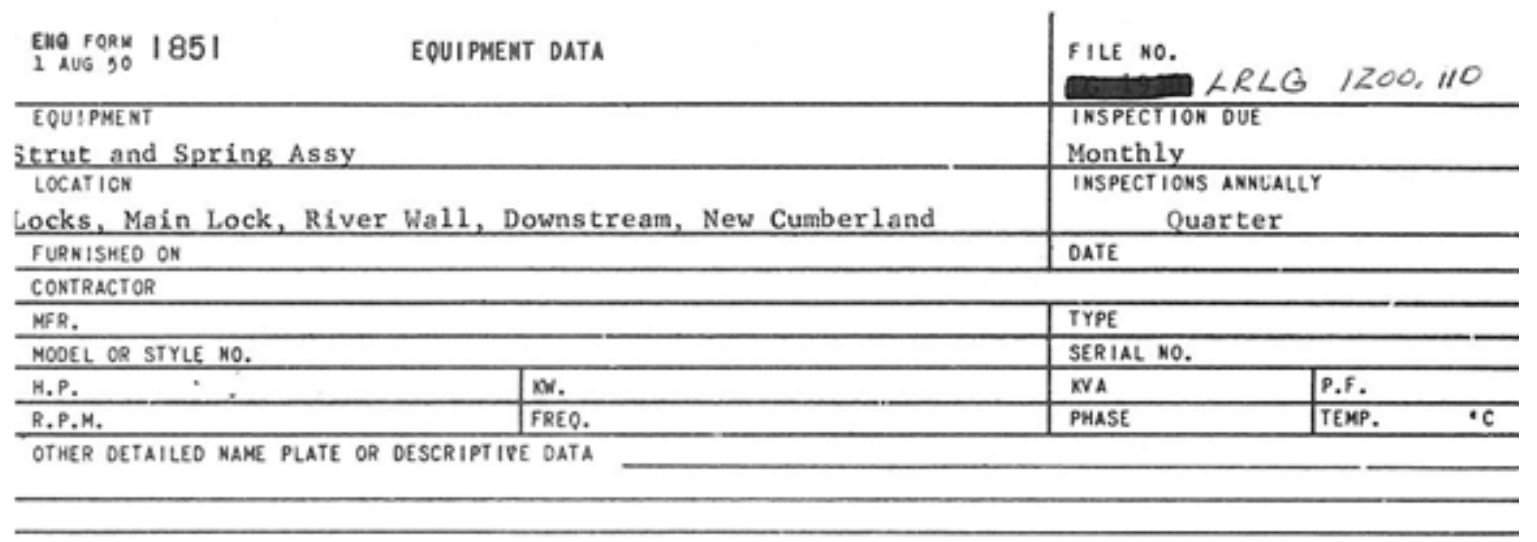




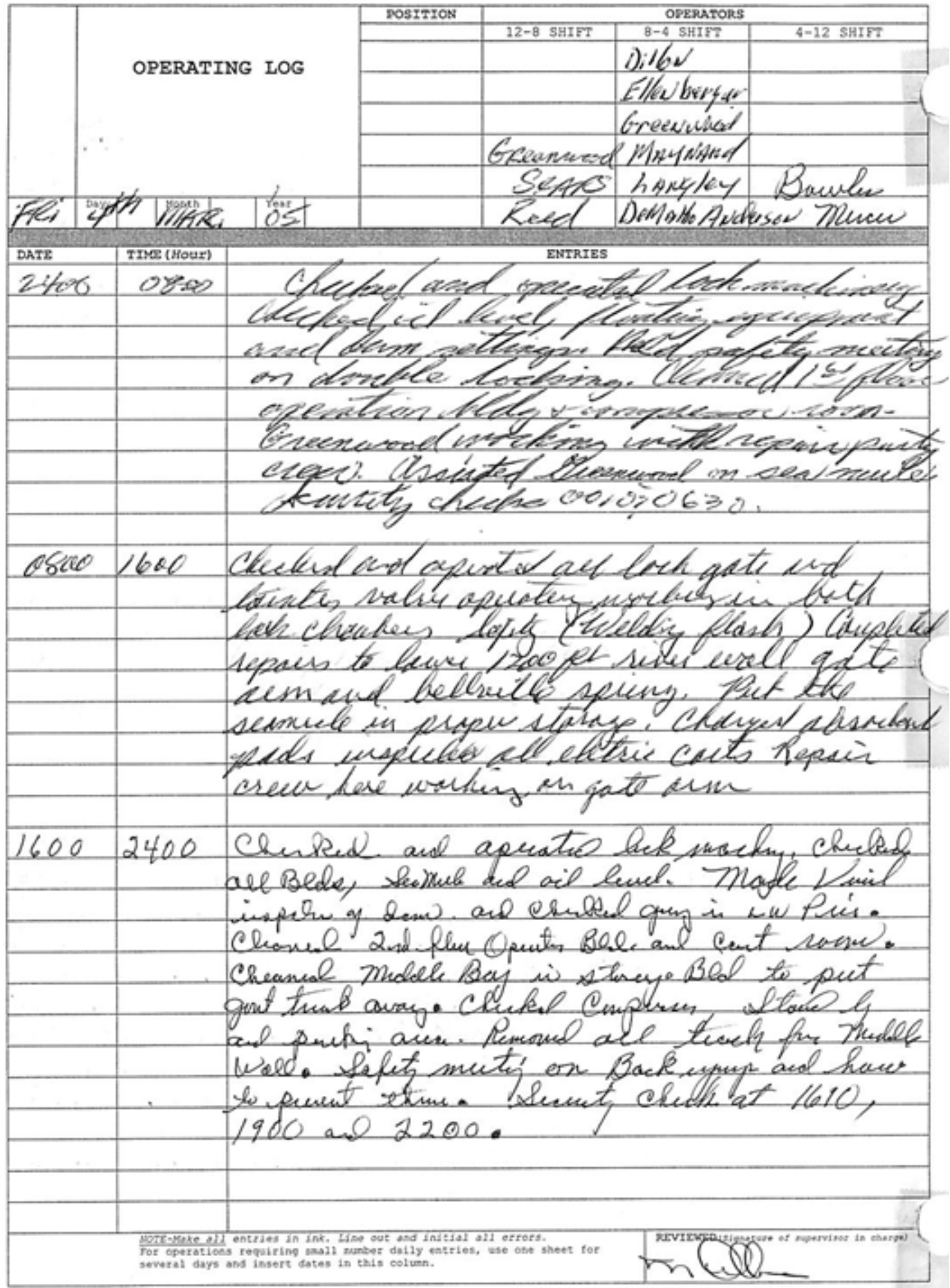




\section{Appendix H: Major Maintenance and Repair Summaries}

\section{H.1 LRD M\&R summaries (2006- 2010)}

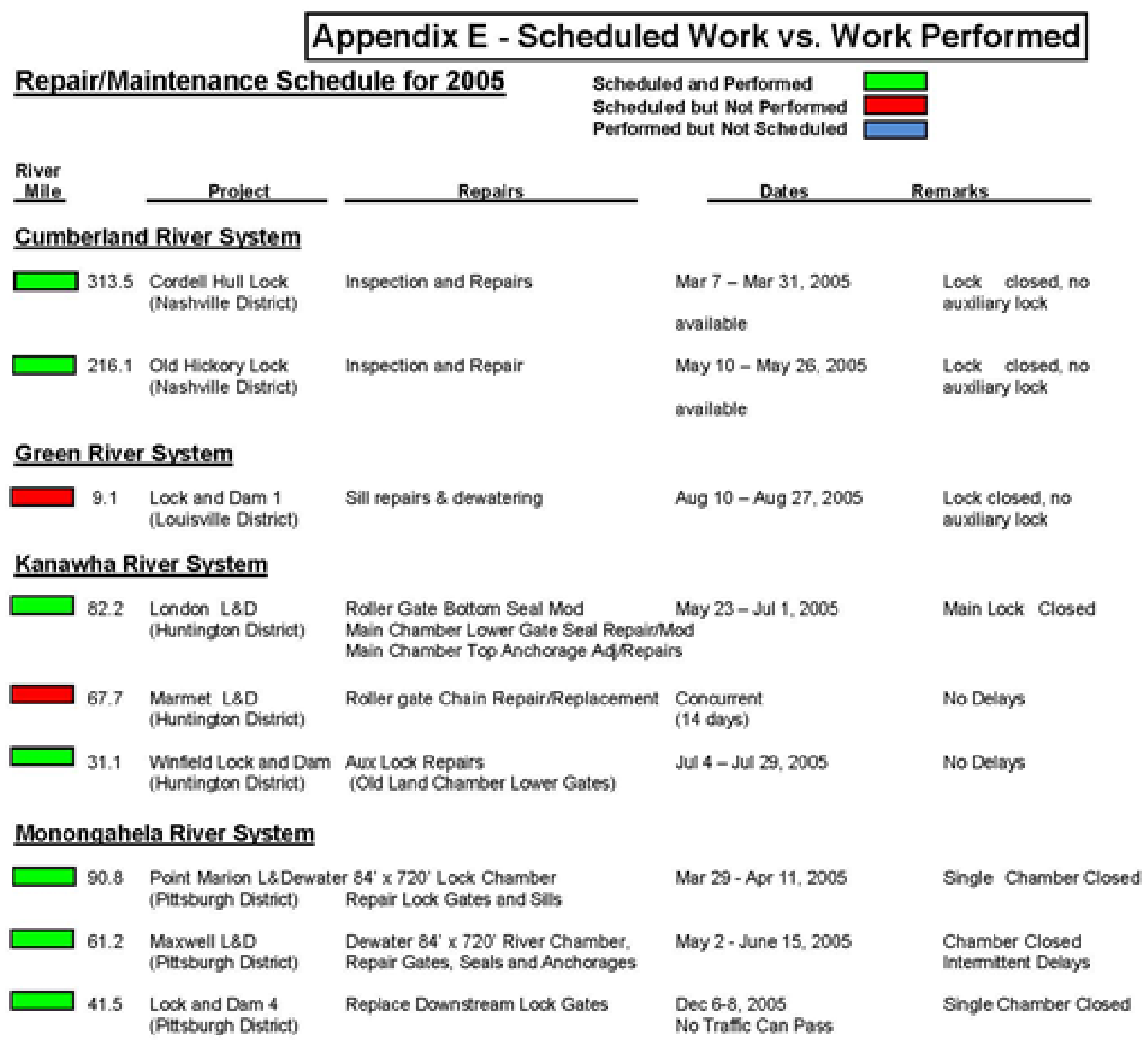




\section{Ohio River System}

\begin{tabular}{|c|c|c|c|c|}
\hline 6.2 & $\begin{array}{l}\text { Emsworth L8D } \\
\text { (Pittsburgh District) }\end{array}$ & Repair Dam Gates 3 \& 11 & Feb 22 - Mar 12, 2005 & No Delays \\
\hline 54.3 & $\begin{array}{l}\text { New Cumberland L\&D } \\
\text { (Pittsburgh District) }\end{array}$ & $\begin{array}{l}\text { Dewater } 110^{\prime} \times 600^{\prime} \text { Land Chamber } \\
\text { Repair Lock Gates and Sills }\end{array}$ & Jul 6 - Aug 18, 2005 & $\begin{array}{l}\text { Small Chamber Closed } \\
\text { No Tratfic Can Pass }\end{array}$ \\
\hline 54.3 & $\begin{array}{l}\text { New Cumberland L\&D } \\
\text { (Piltsburgh District) }\end{array}$ & $\begin{array}{l}\text { Repairs to Service Bridge Lift } \\
\text { Span over } 110^{\circ} \times 600^{\prime} \text { Land Chamber }\end{array}$ & Aug $19-\operatorname{Sep} 2,2005$ & No Delays \\
\hline 84.2 & $\begin{array}{l}\text { Pike Island L\&D } \\
\text { (Piltsburgh District) }\end{array}$ & $\begin{array}{l}\text { Dam Repairs - Tainter Gate } \\
\text { Span over } 110^{\circ} \times 600^{\prime} \text { Land Chamber }\end{array}$ & Sep 12 - Sep 30, 2005 & No Delays \\
\hline 84.2 & $\begin{array}{l}\text { Pike Island LSD } \\
\text { (Pittsburgh District) }\end{array}$ & $\begin{array}{l}\text { Replace River Wall Filling Valve } \\
\text { Span over } 110^{\prime} \times 600^{\prime} \text { Land Chamber }\end{array}$ & Oct 3 - Oct 21, 2005 & Small Chamber Closed \\
\hline 126.4 & $\begin{array}{l}\text { Hannibal LBD } \\
\text { (Pittsburgh District) }\end{array}$ & $\begin{array}{l}\text { Replace Land Wall Emptying } \\
\text { Valve and Renovate Operating } \\
\text { Machinery }\end{array}$ & Oct 24 - Nov 10, 2005 & $\begin{array}{l}\text { Small Chamber Closed } \\
\text { Intermittent Delays }\end{array}$ \\
\hline 161.7 & $\begin{array}{l}\text { Willow Island L8D } \\
\text { (Huntington District) }\end{array}$ & $\begin{array}{l}\text { Tainter gate Side Seal Repairs } \\
\text { Main Chamber Floating Mocring Bat Repa } \\
\text { Mod Aux Lock Miter gates fox Liting }\end{array}$ & $\begin{array}{l}\text { Nov } 14 \text { - Dec 9, } 2005 \\
\text { irs }\end{array}$ & No Delays \\
\hline 237.5 & $\begin{array}{l}\text { Racine Locks and Dam } \\
\text { (Huntington District) }\end{array}$ & $\begin{array}{l}\text { Main Lock Miter Gate Repairs } \\
\text { Emergency Gate inspection/Repairs } \\
\text { Tainter Gate Side Seal Repars }\end{array}$ & Aug 1-Oct 14, 2005 & $\begin{array}{l}\text { Main Lock Closed } \\
\text { Self-Help }\end{array}$ \\
\hline 203.9 & $\begin{array}{l}\text { Bellevile L8D } \\
\text { (Huntington District) }\end{array}$ & $\begin{array}{l}\text { Main Lock Lower Gate Repairs } \\
\text { Aux Lock Upper Gate Srut Arm AdyRepai } \\
\text { Bukhead Crane Cable Replacement }\end{array}$ & Oet $17-$ Nov 11, 2005 & $\begin{array}{l}\text { Main Lock } \\
\text { Intemittent } 8 \mathrm{hr} \\
\text { Closures }\end{array}$ \\
\hline
\end{tabular}

\section{Repair/Maintenance Schedule for 2005 (cont)}
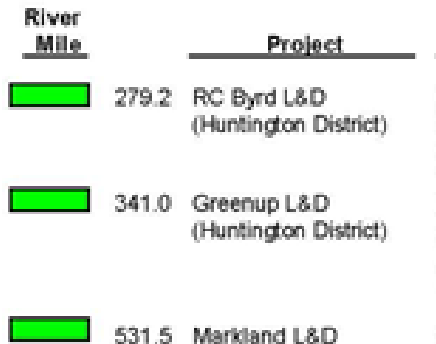

531.5 Markland L8D (Louisville District)

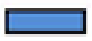

531.5 Markland L8D (Louisville District)

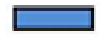

531.5 Markland L8D (Louisville District)

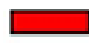

720.7 Cannelton L8D (Louisville District)

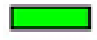

776.1 Newburgh LBD (Louisville District)

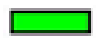

776.1 Newburgh L8D (Louisville District)

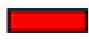

938.9 Locks and Dam 52

962.6 Locks and Dam 53

600 Lower Gate Repairs.
Scheduled and Performed Scheduled but Not Performed Performed but Not Scheduled

Repairs
Culvert Valve Cable Repl.
Stut Arm/Sector Pin Bushing
Cyinder Changeout - Lower Gate
Top Anchorage Adjustments
Main Lock Culvert Valve - RWE
Aux Lock Upper Gate Strut Aum Sprin
Main Lock Culvert Valve - RWF
Main Lock Floating Mooring Bat Repairs
Structural repairs and maintenance
Replace Tainter Gate Cables
Replace Tainter Gate Cables
Structural repairs and maintenance
Rebuild culvert valves

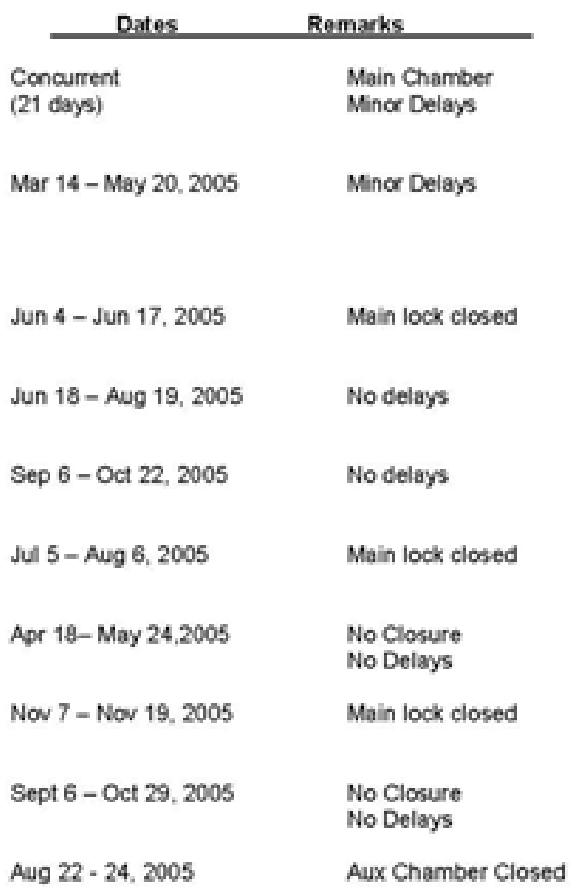

Note: Dates for criginaly scheduled work may not reflect dates of actual work 
Repair/Maintenance Schedule for 2006

River

Mile

Project

Cumberland River System

30.6 Barkley Lock

(Nashville District)

\section{Kanawha River System}

$\square 31.1$ Winfeld Lock and Dam (Huntington District)

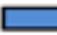

31.1 Winfield Lock and Dam (Huntington District)

67.7 Marmet Locks and Dam (Huntington District)

82.2 London Lock and Dam (Huntington District)

\section{Monongahela River System}

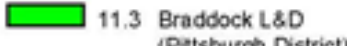

(Phtsburgh District)

3.8 Locks and Dam 3 (Pitsburgh District)

1.5 Lock and Dam 4 (Pittsburgh District)

41.5 Lock and Dam 4 (Pittsburgh District)

108.0 Hildebrand L8D (Pittsburgh District)

108.0 Hildebrand L8D (Pittsburgh District)

\section{Ohio River System}

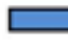

6.2 Emsworth LBD (Pistsburgh District)

प 6.2 Emsworth L8D (Pitsburgh District)

6.2 Emsworth L8D (Pittsburgh District)

$\square 13.3$ Dashields L\&O (Pittsburgh District)

$\square 31.7$ Montgomery L\&D (Pittsburgh District)

31.7 Montgomery LAD (Pittsburgh District)

$\square 31.7$ Montoomery L8D (Pittsburgh District) Small chamber closed

and Seals

Chamber

Gate Bay No. 8
Scheduled and Performed Scheduled but Not Performed Performed but Not Scheduled

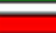

Repairs

Dates

Remarks

Inspection and Repairs

11-27 Jul 06

6 Mar- 5 May 06

Dewater Old River Chamber!

Gate Changeout Top

Anchorage Adjustment Repair

Wall Armor Repair

Flap Cable Replacement

Roller Gate Chain

Roller Track Rim Bolts

Roller Gate Chain Replacement

Roller Gate Chain Replacement

Repair Downstream Miter Gates.

Install New Upstream Maintenance

Bulkhead Sicts and Sill in the

$110^{\prime} \times 720^{\circ}$ Lock Chamber

Dewater $56^{\circ} \times 720^{\prime}$ Land Lock

Chamber, Renovate Filling Valves,

Operating Machinery and Replace

Upstream Miter Gates

Replace Upstream Lock Gates

Renovate $10 x 12$ River Wall Filling

Valve and Operating Machinery

Dewater Single 84' x 600

Chamber, Repair Miter Gates

Install Gear Bowes on Dam Gate 1

Repair Trucks on Dam Gate 5

Repair Downstream Land Wall

Miter Gate in the $110^{\prime} \times 600$

Repair Dam Bulkhead. Main Channel

Repair Lock Gate Anchorages

in the $110^{\circ} \times 600^{\prime}$ Chamber

Repair Upstream Miter Gates damaged in Navigation Accident

Repair Operating Machinery on

Land Wall Emptying Valve

Remove Dam Gate No. 8

Construct Gravity Dam in
7-9 Nov 06

No traffic can pass through lock

31 Aug - 19 Sep 06

19 Jun - 20 Jul 06

and chamber closed Extended river Chamber open Mnor delays

Single chamber closed No traffic can pass through lock

13-22 Nov 06

2 May - 2 Jun 06 Intermittent delays

Single chamber closed No trafic can pass through lock

9- 20 Jan 06

No delays

10-14 Apr 06

Major Delays

14 - 24 Aug 06

No delays

$13-22$ Feb 06

Large chamber closed Small chamber open Major delays

21.23 Mar 06

Large chamber closed Small chamber open Moderate delays

24-30 Mar 06

Large chamber open Small chamber closed Intermittent delays 
Repair/Maintenance Schedule for 2006 (Cont)

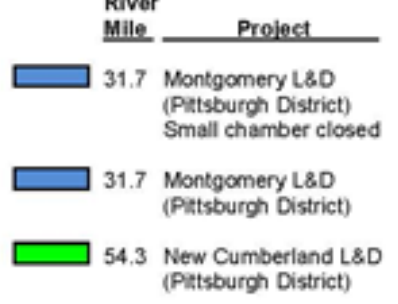

$\square 161.7$ Willow island LBD (Huntington District)

$\square 203.9$ Bellevile Locks and Dam (Huntington District)

237.5 Racine Locks and Dam (Huntington District)

279.2 RC Byrd Locks and Dam (Huntington District)

$\square 341.0$ Greenup Locks and Dam (Huntington District)

$\square 341.0$ Greenup Locks and Dam (Huntington District)

341.0 Greenup Locks and Dam (Huntington Distriet)

436.2 Meldahl Locks and Dam (Huntington District)

720.7 Cannelton L8D (Louisville District)

$\square 776.1$ Newburgh L\&D (Louisville District)

938.9 Locks and Dam 52 (Louisville District)

$\square 938.9$ Locks and Dam 52 (Louisville District)

\section{Tennessee River System}

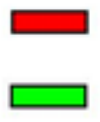

22.4 Kentucky Lock (Nashwille District)

$\square 259.4$ Wison Main Lock (Nashville District)

$\square$ 259.4 Wison Main Lock (Nashville District)

259.4 Wison Main Lock

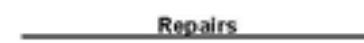

Remove Dam Gate No. 4 Construct Gravity Dam in Gate Bay No. 4

Emergency Repairs to

Dam Gates 6, 5, 2

Renovate River Wall Emptying Valve and Renovate Operating Machinery

Dewater Auxillary Lock Chamber Inspect / Repair Ausiliary Chamber Gates, Dam Tainter Gate Side Seal Repairs

Repar Auxiliary Lower Gates Tainter Gate Repairs due to Barge Accident Bellevile Bulchead Crane Cables

Dam Tainter Gate Side Seal Repairs (2). Mocring Bits

Sector Base Upper River Main both Leaves

Auxiliary Lock Inspection/Repairs Culvert Valve MWE, LWE

Main Lock Inspection/Repairs

Tainter Gate Trunnion Beam and Gate Side Seal

Aux Lock Culvert Valve Repairs Dam Gate Side Seal Repairs Culvert Valves MWF, RWE Quoin and Miter Block Replacement

Structural repairs and maintenance

Culvert valve repairs and maintenance

Structural repairs and maintenance

Reinforce lock wall cells

Inspection and repairs

Repair lower wall

Inspection and repairs

Painting and repair completion Emergengy Repairs
Scheduled and Performed Scheduled but Not Performed Performed but Not Scheduled

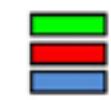

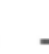

Dates

29 Oct - 20 Nov 06

29 Oct -20 Nov 06

10-27 Oet 06

20 Nov - 15 Dec 06

30 Odt - 17 Nov 06

$25 \operatorname{Sep}-27$ Oct 06

14 - 25 Aug 06

8 May - 2 Jun 06

19 Jun - 7 Jul 06

31 Jul-11 Aug

19 Jun - 28 Jul 06

26 Jun - 29 Jul 06

$15 \mathrm{Apr}-17$ Jun 06

3 Aug - 16 Sep 06

19 Sep - 11 Nov 06

15 Aug - 7 Sep 06

20-25 Mar 06

2- 27 May 06

3 Aug -2 Dec 11
No delays

No delays

Large chamber coen Small chamber closed Mnor delays

Aunoliary lock closed

No delays

No delays

Mnor delays

Minor delays

Ausiliary lock closed No delays

Main lock closed

Sel-help

No delays

No Delays

Main lock closed

Auscliary lock closed

Aunciliary lock closed

Intermittent main lock closures

Lock closed, transit via Barkley Canal and Barkley Lock

Lock elosed, $60 \times 300$ dual ift Auxiliary lock will be avallable

Lock closed, $60 \times 300$ dual Ift Auxiliary lock will be avallable

Lock elosed, $60 \times 300$ dual if Auxiliary

Flcating Caisson used to operate

Lock Intermittently 


Repair/Maintenance Schedule for 2007 $\begin{aligned} & \text { Scheduled and Performed } \\ & \text { Scheduled but Not Performed } \\ & \text { Performed but Not Scheduled }\end{aligned}$

\begin{tabular}{|c|c|c|c|}
\hline & $\begin{array}{l}\text { River } \\
\text { Mile }\end{array}$ & Prolect & Repairs \\
\hline & \multicolumn{3}{|c|}{ Allegheny River System } \\
\hline ए & 14.5 & $\begin{array}{l}\text { C. W. Bill Young L/D } \\
\text { (Pittsburgh District) }\end{array}$ & $\begin{array}{l}\text { Renovate } 8 \times 10 \text { land wall } \\
\text { flling valve and repair } \\
\text { hydraulic pipelines in the } \\
\text { single } 56 \times 360^{\circ} \text { chamber }\end{array}$ \\
\hline & 62.2 & $\begin{array}{l}\text { Lock and Dam } 9 \\
\text { (Pittsburgh District) }\end{array}$ & $\begin{array}{l}\text { Replace hydraulic pipeline } \\
\text { crossovers in the single } \\
56^{\prime} \times 360^{\prime} \text { chamber }\end{array}$ \\
\hline & \multicolumn{3}{|c|}{ Kanamtha River System } \\
\hline & 82.2 & $\begin{array}{l}\text { London L8D } \\
\text { (Huntington Distriet) }\end{array}$ & Roller gate chain replacement \\
\hline & \multicolumn{3}{|c|}{ Monongahela River System } \\
\hline & 11.3 & $\begin{array}{l}\text { Braddock L8D } \\
\text { (Pittsburgh District) }\end{array}$ & $\begin{array}{l}\text { Repair upstream miter gates, } \\
\text { Install new downstream maintenance } \\
\text { bulkhead slots and sill in the } \\
110^{\prime} \times 720^{\prime} \text { lock chamber }\end{array}$ \\
\hline & 11.3 & $\begin{array}{l}\text { Braddock L8D } \\
\text { (Pittsburgh Distriet) }\end{array}$ & $\begin{array}{l}\text { Install new downstream maintenance } \\
\text { bulkhead slods and sill in the } \\
110^{\prime} \times 720^{\circ} \text { lock chamber }\end{array}$ \\
\hline & 23.8 & $\begin{array}{l}\text { Locks and Dam } 3 \\
\text { (Pittsburgh District) }\end{array}$ & $\begin{array}{l}\text { Renovate downstream miter gates } \\
\text { and repair emptying valves in the } \\
56^{\prime} \times 720^{\prime} \text { lock chamber }\end{array}$ \\
\hline & 41.5 & $\begin{array}{l}\text { Lock and Dam } 4 \\
\text { (Pittsburgh District) }\end{array}$ & $\begin{array}{l}\text { Replace upstream lock gates in } \\
\text { the single } 56 \times 720^{\circ} \text { lock chamber }\end{array}$ \\
\hline & 41.5 & $\begin{array}{l}\text { Lock and Dam } 4 \\
\text { (Pittsburgh Distrikt) }\end{array}$ & $\begin{array}{l}\text { Renovate } 10 \times 12 \text { midde wall filing } \\
\text { value and operating machinery in } \\
\text { the single } 56 \times 720^{\circ} \text { lock chamber }\end{array}$ \\
\hline
\end{tabular}

\begin{tabular}{cl} 
Dates & \multicolumn{1}{c}{ Remarks } \\
$12-30$ Mar 07 & $\begin{array}{l}\text { Single chamber open } \\
\text { Intermittent delays }\end{array}$ \\
$21-25$ May 07 & $\begin{array}{l}\text { Single chamber closed } \\
\text { No traffic can pass } \\
\text { through lock }\end{array}$
\end{tabular}

30 Apr - 1 Jun $07 \quad$ No delays

Ohio River System

\begin{tabular}{|c|c|c|c|}
\hline & 6.2 & $\begin{array}{l}\text { Emsworth L\&D } \\
\text { (Pittsburgh District) }\end{array}$ & $\begin{array}{l}\text { Repair downstream middle wall } \\
\text { gate in the } 110^{\circ} \times 600^{\prime} \text { lock chamber }\end{array}$ \\
\hline & 6.2 & $\begin{array}{l}\text { Emsworth L\&D } \\
\text { (Pittsburgh District) }\end{array}$ & $\begin{array}{l}\text { Repair filing and emptying valves } \\
\text { in the } 56^{\prime} \times 360^{\prime} \text { lock chamber }\end{array}$ \\
\hline & 31.7 & $\begin{array}{l}\text { Montgomery L\&D } \\
\text { (Pittsburgh District) }\end{array}$ & $\begin{array}{l}\text { Renovate } 13 \times 14 \text { land wall filling } \\
\text { and emptying valves in the } \\
110^{\prime} \times 600 \text { lock chamber } \\
\text { Emergency Repairs to Dam Gate }\end{array}$ \\
\hline & 84.2 & $\begin{array}{l}\text { Pike Island Locks } \\
\text { (Pittsburgh Distriet) }\end{array}$ & $\begin{array}{l}\text { Renovate land wall slling valve } \\
\text { and operating machinery in the } \\
110^{\prime} \times 600 \text { lock chamber } \\
\text { Repair Dam Gate } 45\end{array}$ \\
\hline & 126.4 & $\begin{array}{l}\text { Hannibal L\&D } \\
\text { (Patsburgh District) }\end{array}$ & $\begin{array}{l}\text { Dewater } 110 \times 1200 \text { lock chamber } \\
\text { and repair miter gates and seals }\end{array}$ \\
\hline & 161.7 & $\begin{array}{l}\text { Wilow Island LSD } \\
\text { (Huntington District) }\end{array}$ & $\begin{array}{l}\text { EM Gate cable replacement } \\
\text { UMW (Main) Strut Arm replacement } \\
\text { Bulkhead seal repairs } \\
\text { Thrust roler repair }\end{array}$ \\
\hline & 203.9 & $\begin{array}{l}\text { Bellevile L8D } \\
\text { (Huntington District) }\end{array}$ & $\begin{array}{l}\text { Tainter Gate Repairs (barge accident) } \\
\text { Hydraulic line repairs }\end{array}$ \\
\hline
\end{tabular}
10- 14 Sep $07 \quad$ Large chamber closed
Major delays
17 Sep - 19 Oct 07
Small chamber closed Large chamber coen Mnor delays
29 Oet - 16 Nov $07 \quad$ Small chamber closed Large chamber coen Intermittent delays
26 Nov-14 Dec 07 Small chamber closed Large chamber coen Mnor delays

16 Jul - 24 Aug 07 Large chamber closed Small chamber open Moderate delays

19 Nov-14 Dec 07 No delays

29 Oct - 16 Nov 07

No delays 


\begin{tabular}{|c|c|c|c|c|c|}
\hline Repai & r/Mair & tenance Schec & le for 2007 (Cont) & $\begin{array}{l}\text { Scheduled and Performe } \\
\text { Scheduled but Not Perf } \\
\text { Performed but Not Sche }\end{array}$ & med \\
\hline & $\begin{array}{l}\text { River } \\
\text { Mile }\end{array}$ & Prolect & Repairs & Dates & Remarks \\
\hline ᄃ & 237.5 & $\begin{array}{l}\text { Radine LAD } \\
\text { (Hunfington District) }\end{array}$ & $\begin{array}{l}\text { UMW Strut Arm repair } \\
\text { Miter gate and valve hydraulic } \\
\text { Cylinder repairs }\end{array}$ & 5 Mar - 30 Mar 07 & Mnor delays \\
\hline & 237.5 & $\begin{array}{l}\text { Racine L\&D } \\
\text { (Hunfington District) }\end{array}$ & Dam tainter gate side seal repairs & $17 \mathrm{Sep}-26 \mathrm{Oct}$ o7 & No delays \\
\hline ᄃ & 237.5 & $\begin{array}{l}\text { Racine L8D } \\
\text { (Huntington District) }\end{array}$ & Replace Bulkhead Crane Cable & $13-16$ Nov 2010 & No delays \\
\hline$\sqsubset$ & 237.5 & $\begin{array}{l}\text { Racine L\&D } \\
\text { (Huntington District) }\end{array}$ & Dam Tainter Line Shat Repairs & 8 - 19 Dec 2010 & No delays \\
\hline & 279.2 & $\begin{array}{l}\text { RC Byrd L\&D } \\
\text { (Huntington District) }\end{array}$ & $\begin{array}{l}\text { Main chamber dewater } \\
\text { Adjust LRW gate and bottom } \\
\text { seal repairs }\end{array}$ & 4 Jun = 6 Jul 07 & $\begin{array}{l}\text { Main lock closed } \\
\text { Sett help }\end{array}$ \\
\hline & 341.0 & $\begin{array}{l}\text { Greenup L8D } \\
\text { (Huntington District) }\end{array}$ & $\begin{array}{l}\text { URW gate machinery repairs } \\
\text { LMW main strut arm repairs }\end{array}$ & $2 \mathrm{Apr}-27$ Apr 07 & Mnor delays \\
\hline & 436.2 & $\begin{array}{l}\text { Meldahi L\&D } \\
\text { (Huntington District) }\end{array}$ & $\begin{array}{l}\text { Aux. Chamber Emergency Gates } \\
\text { Dewater/nspect dam bay } \# 7 \\
\text { Culvert valve rehab (RWF } \propto \text { RWE) }\end{array}$ & 9 Jul - $14 \operatorname{Sep} 07$ & Mner Delays \\
\hline & 436.2 & $\begin{array}{l}\text { Meldahl LSD } \\
\text { (Huntington District) }\end{array}$ & $\begin{array}{l}\text { Auxilary Lock Emergency Gare Rehab } \\
\text { Dewater/nnspect dam bay } 17\end{array}$ & $19 \mathrm{Nov}-7 \mathrm{Dec} 07$ & Mnor Delays \\
\hline & 531.5 & $\begin{array}{l}\text { Markland LBD } \\
\text { (Louisville District) }\end{array}$ & $\begin{array}{l}\text { Structural repairs and maintenance } \\
\text { inspection }\end{array}$ & 31 May - 15 Jun 07 & Main lock closed \\
\hline & 531.5 & $\begin{array}{l}\text { Markland LBD } \\
\text { (Louisville District }\end{array}$ & $\begin{array}{l}\text { Emergency Repairs, Mter Gate } \\
\text { Cracks }\end{array}$ & $9-31$ Jul 07 & Auxiliary lock closed \\
\hline & 606.8 & $\begin{array}{l}\text { MeAlpine L8D } \\
\text { (Louisville District) }\end{array}$ & Main Lock Gate Repairs & $18-22$ Jun 07 & Lock chamber closed \\
\hline & 720.7 & $\begin{array}{l}\text { Cannelton L\&D } \\
\text { (Louisvile District) }\end{array}$ & $\begin{array}{l}\text { Structural repairs and maintenance } \\
\text { inspection }\end{array}$ & 25 Jun - 31 Jul 07 & Main lock closed \\
\hline & 846.0 & $\begin{array}{l}\text { JT Myers LSD } \\
\text { (Louisville District) }\end{array}$ & Rebuild eulvert valves & 16 Apr - 19 May 07 & Small Chamber closed \\
\hline & 938.9 & $\begin{array}{l}\text { Locks and Dam } 52 \\
\text { (Loulsville District) }\end{array}$ & Structural repairs & 7 - 13 Aug 07 & Main lock closed \\
\hline & 938.9 & $\begin{array}{l}\text { Locks and Dam } 52 \\
\text { (Louisville District) }\end{array}$ & Structural repairs & 21 - 27 Aug 07 & Main lock closed \\
\hline & 938.9 & $\begin{array}{l}\text { Looks and Dam } 52 \\
\text { (Louisville District) }\end{array}$ & Beartrap repairs & 28 Aug -13 Nov 07 & No Delays \\
\hline & Tennes & eee River System & & & \\
\hline & 22.4 & $\begin{array}{l}\text { Kentucky Lock } \\
\text { (Nashrville District) }\end{array}$ & Inspection and repairs & 21 Aug - $13 \mathrm{Sep} 07$ & $\begin{array}{l}\text { Lock closed, transit via Barkley Canal } \\
\text { and Barkley Lock }\end{array}$ \\
\hline & 206.7 & $\begin{array}{l}\text { Pickwick Aux Loek } \\
\text { (Nastrville District) }\end{array}$ & Install new tow-haulage unit & 19 Mar - 10 Apr 07 & Auncliary Lock elosed \\
\hline & 206.7 & $\begin{array}{l}\text { Pickwick Main Lock } \\
\text { (Nashville District) }\end{array}$ & Inspection and repairs & $10-23$ Jul 07 & Main lock closed \\
\hline & 259.4 & $\begin{array}{l}\text { Wilson Aux Loek } \\
\text { (Nastiville District) }\end{array}$ & Repair lower damaged gate & 5 - 21 Jun 07 & Auncliary lock closed \\
\hline & 471.0 & $\begin{array}{l}\text { Chickamauga Lock } \\
\text { (Nashville District) }\end{array}$ & Inspection & 20 Mar - 10 Apr 07 & $\begin{array}{l}\text { Single lock closed, no traffic } \\
\text { can pass through project }\end{array}$ \\
\hline
\end{tabular}




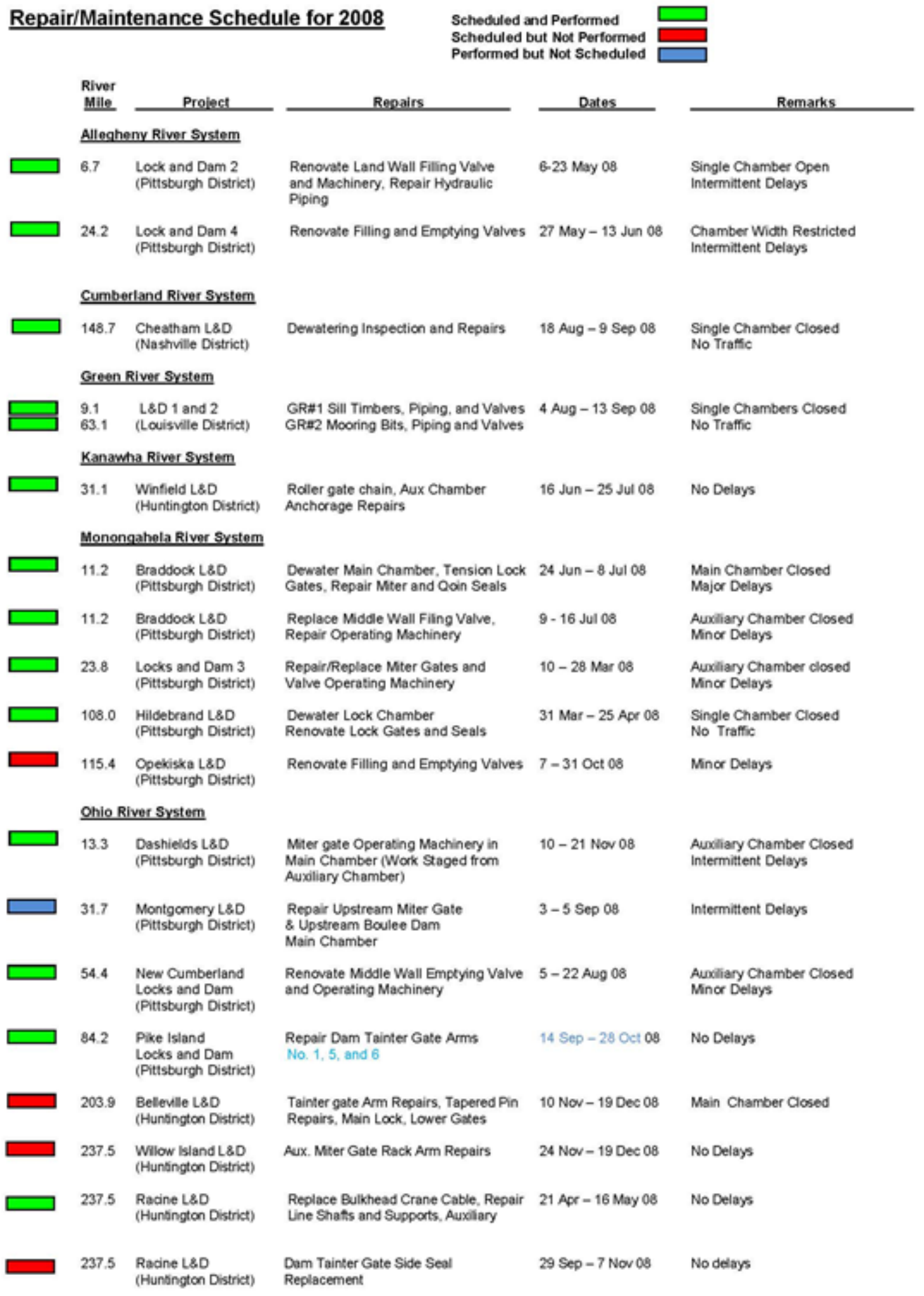




\begin{tabular}{|c|c|c|c|c|c|}
\hline \multicolumn{4}{|c|}{ Repair/Maintenance Schedule for 2008 (Cont) } & $\begin{array}{l}\text { Scheduled and Performed } \\
\text { Scheduled but Not Performed } \\
\text { Performed but Not Scheduled }\end{array}$ & \multirow[b]{2}{*}{ Remarks } \\
\hline & $\begin{array}{l}\text { River } \\
\text { Mile }\end{array}$ & Prolect & Repairs & Dates & \\
\hline & 237.5 & $\begin{array}{l}\text { Radine L\&D } \\
\text { (Hunfington Distriet) }\end{array}$ & Dam Tainter Line Shat & $1-19 \mathrm{Dec} 0 \mathrm{~s}$ & No delays \\
\hline & 237.5 & $\begin{array}{l}\text { Radine L\&D } \\
\text { (Huntington District) }\end{array}$ & Dam Tainter Line Shat Repairs & $8-19$ Dec 08 & No delays \\
\hline & 279.2 & $\begin{array}{l}\text { RC Byrd LBD } \\
\text { (Huntington District) }\end{array}$ & $\begin{array}{l}\text { Rehab Modde Wall Fill Valve } \\
\text { Lower Wall Empty Culvert Valve }\end{array}$ & $10 \mathrm{Mar}-18 \mathrm{Apr} 08$ & Aunilary Chamber Closed \\
\hline & 279.2 & $\begin{array}{l}\text { RC Byrd L\&D } \\
\text { (Huntington District) }\end{array}$ & Main Look Lower Gate Repairs & 27 Ot -28 Nov 08 & Main Chamber Closed \\
\hline & 341.1 & $\begin{array}{l}\text { Greenup L8D } \\
\text { (Huntington District) }\end{array}$ & Emergency Gate Rehab - Prelim. Work & 19 May- 13 Jun 08 & Auniliary Chamber Closed \\
\hline & 341.1 & $\begin{array}{l}\text { Greenup L8D } \\
\text { (Huntington District) }\end{array}$ & $\begin{array}{l}\text { Emergeney Gate Rehab Instalation } \\
\text { Midde Wall Empty Culvert Valve Rehab }\end{array}$ & 28 Jul $-26 \operatorname{Sep} 08$ & Auniliary Chamber Closed \\
\hline & 341.1 & $\begin{array}{l}\text { Greenup L8D } \\
\text { (Huntington District) }\end{array}$ & $\begin{array}{l}\text { Emergency Gate Rehab Instalation } \\
\text { Middle Wall Empty Culvert Valve Rehab }\end{array}$ & $27 \operatorname{Sep}-5 \operatorname{Dec} 08$ & Auniliary Chamber Closed \\
\hline & 606.8 & $\begin{array}{l}\text { McAupine LSD } \\
\text { (Loulsville District) }\end{array}$ & $\begin{array}{l}\text { Tainter Gate \#1, Wire } \\
\text { Rope Replacement }\end{array}$ & $10-25$ Jul 08 & No Delays \\
\hline & 720.7 & $\begin{array}{l}\text { Cannelton L\&D } \\
\text { (Louisville District) }\end{array}$ & $\begin{array}{l}\text { Rehab Two Culvert Valves, Sector } \\
\text { Gate Machinery. Major Maintenance }\end{array}$ & 8 Apr -22 Jun 08 & Ausiliary Chamber Closed \\
\hline & 720.7 & $\begin{array}{l}\text { Cannelton L\&D } \\
\text { (Louisville District) }\end{array}$ & $\begin{array}{l}\text { Upper Gate Major Maintenance } \\
\text { and Anchor Modifications }\end{array}$ & 23Jun - 29 Jul 08 & Main Chamber Closed \\
\hline & 720.7 & $\begin{array}{l}\text { Cannelton L\&D } \\
\text { (Louisville District) }\end{array}$ & Upper Gate Major Maintenance & 9 Oct $-15 \mathrm{Nov}$ os & Aunoliary Chamber Closed \\
\hline & 776.0 & $\begin{array}{l}\text { Newburgh L\&D } \\
\text { (Louisvile District) }\end{array}$ & $\begin{array}{l}\text { Replace tainter gate Cable } \\
\text { Connections }\end{array}$ & 6 Oct -15 Nov 08 & No Delays \\
\hline & 846.0 & $\begin{array}{l}\text { JT Myers L8D } \\
\text { (Louisville District) }\end{array}$ & $\begin{array}{l}\text { Dam Pier \#11 Concrete Erosion } \\
\text { Repair }\end{array}$ & $16 \mathrm{Sep}-4 \mathrm{Oct} 08$ & No Delays \\
\hline & \multicolumn{5}{|c|}{ Tennessee River System } \\
\hline & 206.7 & $\begin{array}{l}\text { Pickwick L\&D } \\
\text { (Nasthville District) }\end{array}$ & Dewatering for Inspection and Repairs & 28 May -17 Jun 08 & Auniliary Chamber Closec \\
\hline & 206.7 & $\begin{array}{l}\text { Pickwick L\&D } \\
\text { (Nashnille District) }\end{array}$ & Dewatering for Inspection and Repairs & $8-21$ Jul 08 & Main Chamber Closed \\
\hline & 274.3 & $\begin{array}{l}\text { Wheeler L\&D } \\
\text { (Nashville District) }\end{array}$ & Dewatering for Inspection and Repairs & 15 Apr - 5 May 08 & Main Chamber Closed \\
\hline
\end{tabular}

Note: Dates for originaly scheduled work may nok reflect dates of actual work 


\section{Repair/Maintenance Schedule for 2009}

River

Mile

Allegheny River System

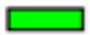

6.7

Lock and Dam 3
CW Bill Young
(Pittsburgh) District)

Cumberland River System

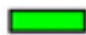

216.2 Old Hickory

(Nashville) District)

Dewater and Inspect Chamber

Kanamha River System

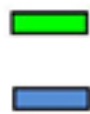

31

Winfield L\&D

(Huntington District)

31.1 Winfield L\&D

(Huntington District)

Monongahela River System

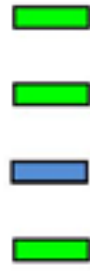

11.2

Braddock LBD

(Pittsburgh District)

11.2 Braddock L8D (Pittsburgh District)

23.8 Lock and Dam 3 (Pittsburgh District)

91.0 Point Marion L8D (Pittsburgh District)

\section{Ohio River System}

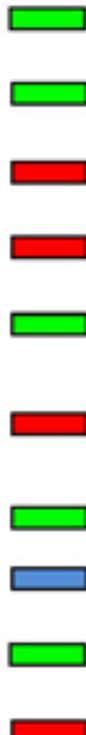

6.2 Emsworth L\&D (Pittsburgh District)

13.3

DaShields L\&D (Pittsburgh District)

31.7 Montgomery L8D (Pittsburgh District)

31.7 Montgomery L\&D (Pittsburgh District)

842 Pike Island $L 80$ (Pittsburgh District)

126.4 Hannibal L\&D (Pittsburgh District)

203.9 Belleville L8D (Hunfington District)

203.9 Belleville L8D (Hunington District)

237.5 Racine L8D (Huntington District)

279.2 RC Byrd L8D (Hunington District)

Replace DS Miter Gates

RWE Valve Repair, Roller Gate

Chain

Continue RWE Valve Repair

Repair Miter and Qoin Seals

Replace Land Wall Filling Valve Renovate Operating Machinery

Dewater Chamber and Repair 8 'Cylindrical Valvesy

Repair Emptying Valves Floating Mocring Bits

Replace Land Wall Filling Valve Renovate Operating Machinery Rehab

Dewater and Inspect Repair Gate Operating Machinery

Scheduled and Performed

Scheduled but Not Performed

Performed but Not Scheduled

\begin{tabular}{l} 
Repairs \\
\hline Replace DS Miter Gates \\
Repair Gate Operating Machinery
\end{tabular}

Dates

$14-23$ Apr 09

Cosure

27 Oct -17 Nov 09

Single Chamber Closure

Repair Gate Operating Machinery

Renovate Land Wall Emptying Valve

$30 \mathrm{Nav}-7 \mathrm{Dec} 0$ No Delays Anticipated

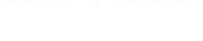

11 May - 19 Jun 09

Aurliary Chamber No Delays Anticipated

Audilary Chamber No Delays Anticipated

23 Mar -3 Apr $09 \quad$ Minor Delays

$6-24$ Jul 09

Main Chamber Closed

Repair US Land Wall and DS Middle

6 - 24 Jul 09 Wall Miter Gates

Continuation of Repairs to Dam Gates

4 - 15 May 09

$30 \mathrm{Nov}=18 \mathrm{Dec} 09$

Continuation of Repairs to Dam Gates

Repair Operating Machinery and

8 Sep -16 Oct 09

Auxiliary Chamber Closed No Delays Anticlpated

Tainter gate Amm Repairs, Tapered Pin Repairs, Main Lock, Lower Gates

1 - 19 Jun 09

Auxiliary Chamber Closed

No Delays Anticipated

Main Chamber Intermittent Delays

Lower River Gate Gudgion Pin Repairs

22 Jun - 1 Jul 09

Main Chamber Closed

Emergency Gate Sheave/Anchorage Lower River Wall Miter Date Repairs
29 Jul $=21$ Aug 09 $16 \mathrm{Nov}-18 \mathrm{Dec} 09$

5 Oct -13 Nov 09

No Delays

Main Chamber Closed 


\begin{tabular}{|c|c|c|c|c|c|}
\hline \multicolumn{4}{|c|}{ Repair/Maintenance Schedule for 2009 (Cont) } & $\begin{array}{l}\text { Scheduled and Performed } \\
\text { Scheduled but Not Performed } \\
\text { Performed but Not Scheduled }\end{array}$ & \multirow[b]{2}{*}{ Remarks } \\
\hline & $\begin{array}{l}\text { River } \\
\text { Mile }\end{array}$ & Prolect & Repairs & Dates & \\
\hline & 341.1 & $\begin{array}{l}\text { Greenup L8D } \\
\text { (Hunfington District) }\end{array}$ & $\begin{array}{l}\text { Dewater and Inspect in Preparation for } \\
\text { Main Chamber Closure }\end{array}$ & 29 Jul - 21 Aug 09 & $\begin{array}{l}\text { Auniliary Chamber } \\
\text { No Delays }\end{array}$ \\
\hline & 341.1 & $\begin{array}{l}\text { Greenup L8D } \\
\text { (Hunfington District) }\end{array}$ & $\begin{array}{l}\text { Dewater and Inspect } \\
\text { Mooring Bit Repairs }\end{array}$ & $50 \mathrm{Ot}-7 \mathrm{Nov} 09$ & Main Chamber Closed \\
\hline & 436.2 & $\begin{array}{l}\text { Meldahl L\&D } \\
\text { (Hunfington District) }\end{array}$ & $\begin{array}{l}\text { Miter Gate Preliminary, Miter Gate } \\
\text { Sector Base Repairs }\end{array}$ & 24 Aug - 30 Sep 09 & No Delays \\
\hline & 531.5 & $\begin{array}{l}\text { Markland L\&D } \\
\text { (Louisville District) }\end{array}$ & $\begin{array}{l}\text { Dewater and inspect } \\
\text { Culvert Valve Machinery }\end{array}$ & $\begin{array}{l}28 \text { Apr }-23 \text { May } 09 \\
14 \text { Sep }-27 \text { Sep } 09\end{array}$ & Main Chamber Closed \\
\hline & 531.5 & $\begin{array}{l}\text { Markland L\&D } \\
\text { (Louisville District) }\end{array}$ & $\begin{array}{l}\text { Emergency Repairs to the Lower } \\
\text { Gate Leaves }\end{array}$ & $27 \operatorname{Sep}-31$ Dec 09 & Main Chamber Closed \\
\hline & 720.7 & $\begin{array}{l}\text { Cannelton LSD } \\
\text { (Louisville District) }\end{array}$ & $\begin{array}{l}\text { Major Maintenance and Anchorage } \\
\text { Mod, Emergency Gate Sheaves }\end{array}$ & 1 Jun - 11 Jul 09 & Main Chamber Closed \\
\hline & 846.0 & $\begin{array}{l}\text { JT Myers L8D } \\
\text { (Louisville District) }\end{array}$ & $\begin{array}{l}\text { Anchorage Mod, Replace Miter and } \\
\text { Ouioin Elocks, Pintles and Gudgeon }\end{array}$ & 14 Jul $=25$ Aug 09 & Auneliary Chamber Closed \\
\hline & 846.0 & $\begin{array}{l}\text { JT Myers LBD } \\
\text { (Louisville District) }\end{array}$ & Dewater and inspected & 28 Aug - $9 \operatorname{Sep} 09$ & Main Chamber Closed \\
\hline & 918.5 & $\begin{array}{l}\text { Smithland L\&D } \\
\text { (Louisville District) }\end{array}$ & Tainter gate Repairs & $14 \operatorname{Sep}-10$ Oet 09 & No Delays \\
\hline & 964.4 & $\begin{array}{l}\text { L8D } 52 \\
\text { (Louisville District) }\end{array}$ & Sill Repairs & $14 \operatorname{Sep}-27 \operatorname{Sep} 09$ & Auxiliary Chamber Closed \\
\hline & \multicolumn{5}{|c|}{ Tennessee River System } \\
\hline & 259.4 & $\begin{array}{l}\text { Wilson LBD } \\
\text { (Nashville District) }\end{array}$ & $\begin{array}{l}\text { Dewater and Inspect Chamber } \\
\text { Wall Armor \& Culvert Valve Work }\end{array}$ & 14 Jul - 11 Ang 09 & Main Chamber Closed \\
\hline & 349.0 & $\begin{array}{l}\text { Guntersville L\&D } \\
\text { (Nasthille District) }\end{array}$ & Dewater and Inspect Chamber & 2 Jun - 23 Jun 09 & Main Chamber Closed \\
\hline & 424.7 & $\begin{array}{l}\text { Nickajack LSD } \\
\text { (Nastrville District) }\end{array}$ & Dewater and inspect Chamber & $21 \mathrm{Apr}-12$ May 09 & Single Chamber Closed \\
\hline & 471.0 & $\begin{array}{l}\text { Chickamauga L \& D } \\
\text { (Nastrville District) }\end{array}$ & $\begin{array}{l}\text { LRW Embedded Anchorage } \\
\text { Replacement }\end{array}$ & 27 Apr - 10 May 09 & Main Chamber Closed \\
\hline
\end{tabular}




\section{Repair/Maintenance Schedule for $\mathbf{2 0 1 0}$}

River

Mile

Prolect

\section{Allegheny River System}

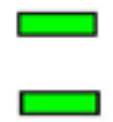

6.7

Lock and Dam 2

(Pittsburgh District)

24.2 Lock and Dam 4 (Pittsburgh District)

\section{Kanawha River System}

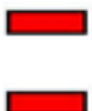

31.1 Winfield L\&D (Huntington District)

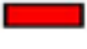

82.8 London L\&D (Huntington District)

Monongahela River System

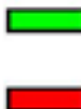

11.2 Braddock LBO (Pittsburgh District)

$\square$

11.2 Braddock L\&O (Pittsburgh District)

\section{Ohio River System}

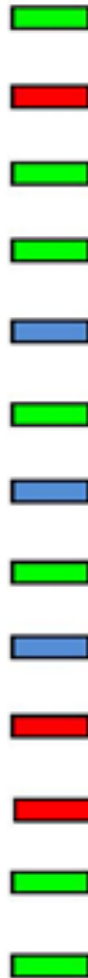

Emsworth LSD (Pittsburgh District)

$\square$ 6.2 Emsworth L\&D (Pittsburgh District)

$\square \quad 31.7 \quad$ Montgomery L\&D (Pittsburgh District)

84.2 Pike Island L\&D (Pittsburgh District)

161.7 Willow Island L\&D (Huntington District)

203.9 Belleville L\&D (Hunitington District)

237.5 Racine LAD (Hunfington District)

279.2 RC Byrd LAD (Huntington District)

341.1 Greenup LBD

436.2 Meldahl LSD (Huntington District)

436.2 Meldahl L\&D (Huníngton District)

531.5 Markland L\&D (Louisville District)

531.5 (Huntington District)
Dewater and inspect

Renovate Emptying Valves $2,3,4,86$

Replace 2 Remaining Roller Gate Chains (Dam Work)

Roller Gate Chain Replacement Sill Modifcations (Dam Work)

Dewater Chamber. Repain/Replace Miter Sills, Gates, Seals, and Anodes

Replace MWEV, Renovate Operating Machinery

Dewater Main Chamber Renovate Emptying Valves

Repair U/S Miter Gates and Gate Operating Machinery

Emergency Repairs

Gates 3, 7, 9, \& 10

Install New Miter Gates

Aux. Lock Lower Mter Gate, Repairs to Quoin and Miter Blocks

Main Chamber, Upper Gate Opening Machinery, Side Seal Repairs

Dam Bukchead Crane Rope

replacement

Dewater and inspect. Adjust Miter Gate Alignment, Sector Base, and Sirut Rehab

Replace Anchorage Arms Strut Pins \& Sector Gear Repairs

LowerGate Storage Beam Installation Miter Gate Anchorage Work

Miter Gate Prep and Instalation Sector Base Repairs

Lower Mter Gate Repairs \& Installation Dependant on river conditions

Uniload New Lower Miter Gate Leaves Ac Louisville Repair Station
Scheduled and Performed

Scheduled but Not Performed

Performed but Not Scheduled

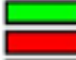




\begin{tabular}{|c|c|c|c|c|c|}
\hline Repa & r/Mail & tenance Sche & le for 2010 (Cont) & $\begin{array}{l}\text { eduled and Performe } \\
\text { eduled but Not Perfo } \\
\text { brmed but Not Schec }\end{array}$ & ed \\
\hline & $\begin{array}{l}\begin{array}{l}\text { River } \\
\text { Mile }\end{array} \\
\end{array}$ & Prolect & Repairs & Dates & Remarks \\
\hline & 531.5 & $\begin{array}{l}\text { Markland L \&D } \\
\text { (Louisvile District) }\end{array}$ & $\begin{array}{l}\text { Unload New Upper gate leaves } \\
\text { At Markland L } 80\end{array}$ & $1-31$ Dec 10 & No Delays \\
\hline & 606.8 & $\begin{array}{l}\text { McAlpine LBD } \\
\text { Old Chamber } \\
\text { (Louisville District) }\end{array}$ & $\begin{array}{l}\text { Rehab Culvert Valve Machinery And } \\
\text { Gate Machinery Prep for Gate Change }\end{array}$ & 1 Apr - 14 May 10 & No Delays \\
\hline & 606.8 & $\begin{array}{l}\text { McAlpine LBD } \\
\text { (Loulsville District) }\end{array}$ & New Lower Gate Installation & 1 Jun - 15 Jul 10 & Old Chamber Closed \\
\hline & 606.8 & $\begin{array}{l}\text { McAlpine LBD } \\
\text { (Louisville District) }\end{array}$ & $\begin{array}{l}\text { Replace pintles \& gudgeon pins } \\
\text { \& bushings }\end{array}$ & 19 Apr - 5 Aug 10 & New Chamber Closed \\
\hline & 720.7 & $\begin{array}{l}\text { Cannelton LSD } \\
\text { (Louisville District) }\end{array}$ & $\begin{array}{l}\text { Dewater and Inspect Main Chamber } \\
\text { (Anchorages not Mitering) }\end{array}$ & 19 Jul - 7 Aug 10 & Main Chamber Closed \\
\hline & 846.0 & $\begin{array}{l}\text { JT Myers L8D } \\
\text { (Louisville District) }\end{array}$ & $\begin{array}{l}\text { Replace LMW Anchor Arm in Main } \\
\text { Chamber }\end{array}$ & 17 - 26 May 10 & Main Chamber Closed \\
\hline & 918.5 & $\begin{array}{l}\text { Smithland L8D } \\
\text { (Louisville District) }\end{array}$ & $\begin{array}{l}\text { Dewater and Inspect } \\
\text { Land Chamber }\end{array}$ & $12-28$ Oct 10 & Land Chamber Closed \\
\hline & 918.5 & $\begin{array}{l}\text { Smthland L8D } \\
\text { (Loulsville District) }\end{array}$ & $\begin{array}{l}\text { Dewater and Inspect } \\
\text { River Chamber }\end{array}$ & $29 \mathrm{Ott}-15$ Nov 10 & River Chamber Closed \\
\hline & 964.4 & $\begin{array}{l}\text { L8D 52/53 } \\
\text { (Loulsville District) }\end{array}$ & $\begin{array}{l}\text { 52: Lower Miter Gate, Cell Bands } \\
\text { 53: Lower Miter Gate, Culvert Valves }\end{array}$ & 16 Aug -9 Oct 10 & $\begin{array}{l}52 \text { Main Chamber Closed } \\
53 \text { Main Chamber Closed }\end{array}$ \\
\hline & Tennes & see River System & & & \\
\hline & 22.3 & $\begin{array}{l}\text { Kentucky Lock } \\
\text { (Nashville District) }\end{array}$ & Timbers Floating Boom Wall & $8 \mathrm{Feb}=18 \mathrm{Mar} 10$ & No Delays \\
\hline & 471.0 & $\begin{array}{l}\text { Chickamauga Lock } \\
\text { (Nashville District) }\end{array}$ & Dewater and inspect & $20 \mathrm{Jul}$ - 16 Aug 10 & Single Chamber Closed \\
\hline & 529.9 & $\begin{array}{l}\text { Watts Bar Lock } \\
\text { (Nastrville District) }\end{array}$ & $\begin{array}{l}\text { Dewater and inspect } \\
\text { Will not return for another } 10 \text { years }\end{array}$ & 12 Oct -2 Nov 10 & Single Chamber Closed \\
\hline & 471.0 & $\begin{array}{l}\text { Fort Loudon Lock } \\
\text { (Nashville District) }\end{array}$ & $\begin{array}{l}\text { Dewater and Inspect } \\
\text { TVA will paint lower miter gates }\end{array}$ & 20 Apr - 11 May 10 & Single Chamber Closed \\
\hline & $\begin{array}{l}\text { Clinch } \\
\text { River }\end{array}$ & $\begin{array}{l}\text { Metion Hill Lock } \\
\text { (Nasthville District) }\end{array}$ & Dewater and Inspect & $8-29$ Jun 10 & Single Chamber Closed \\
\hline
\end{tabular}




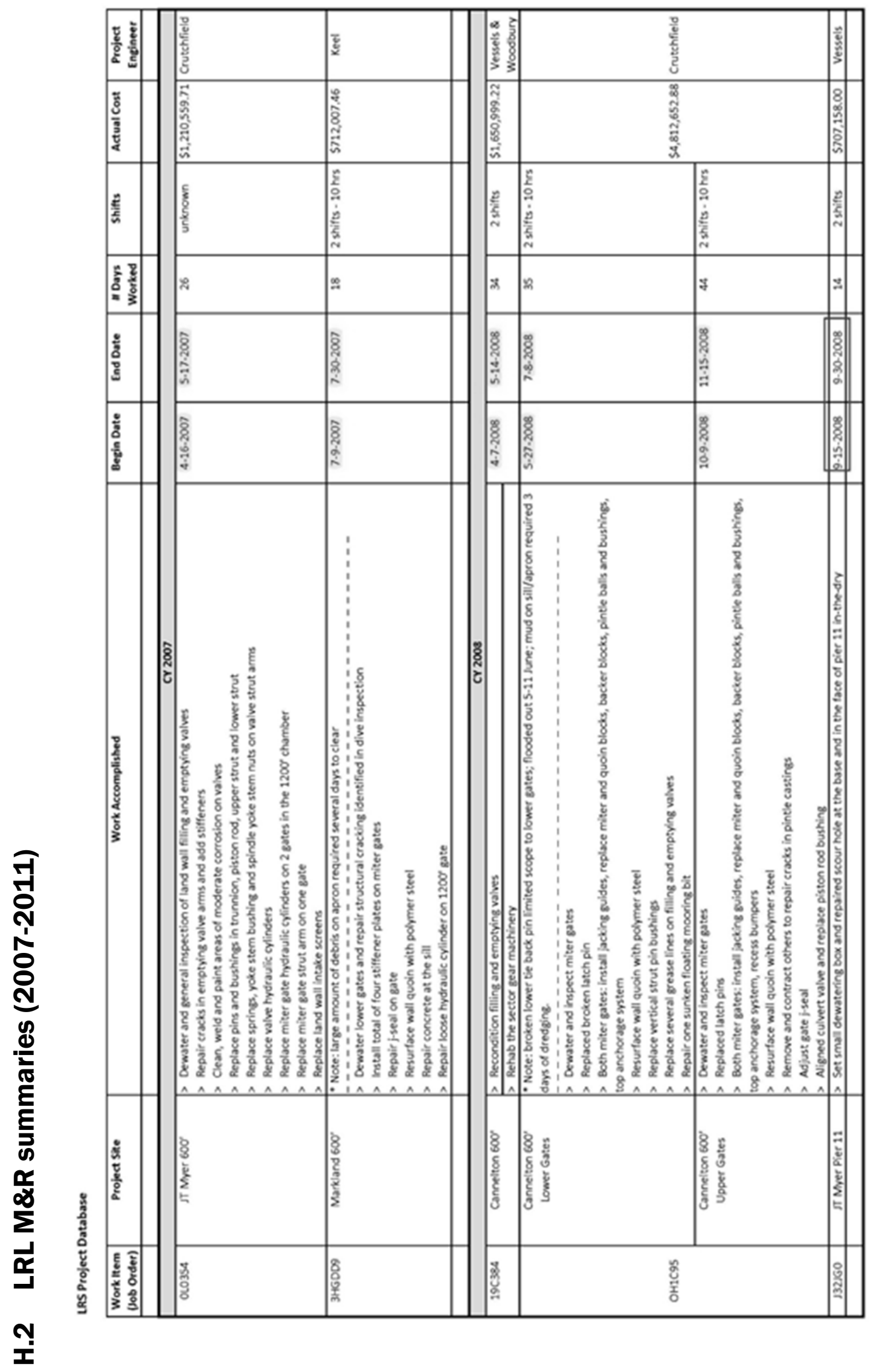




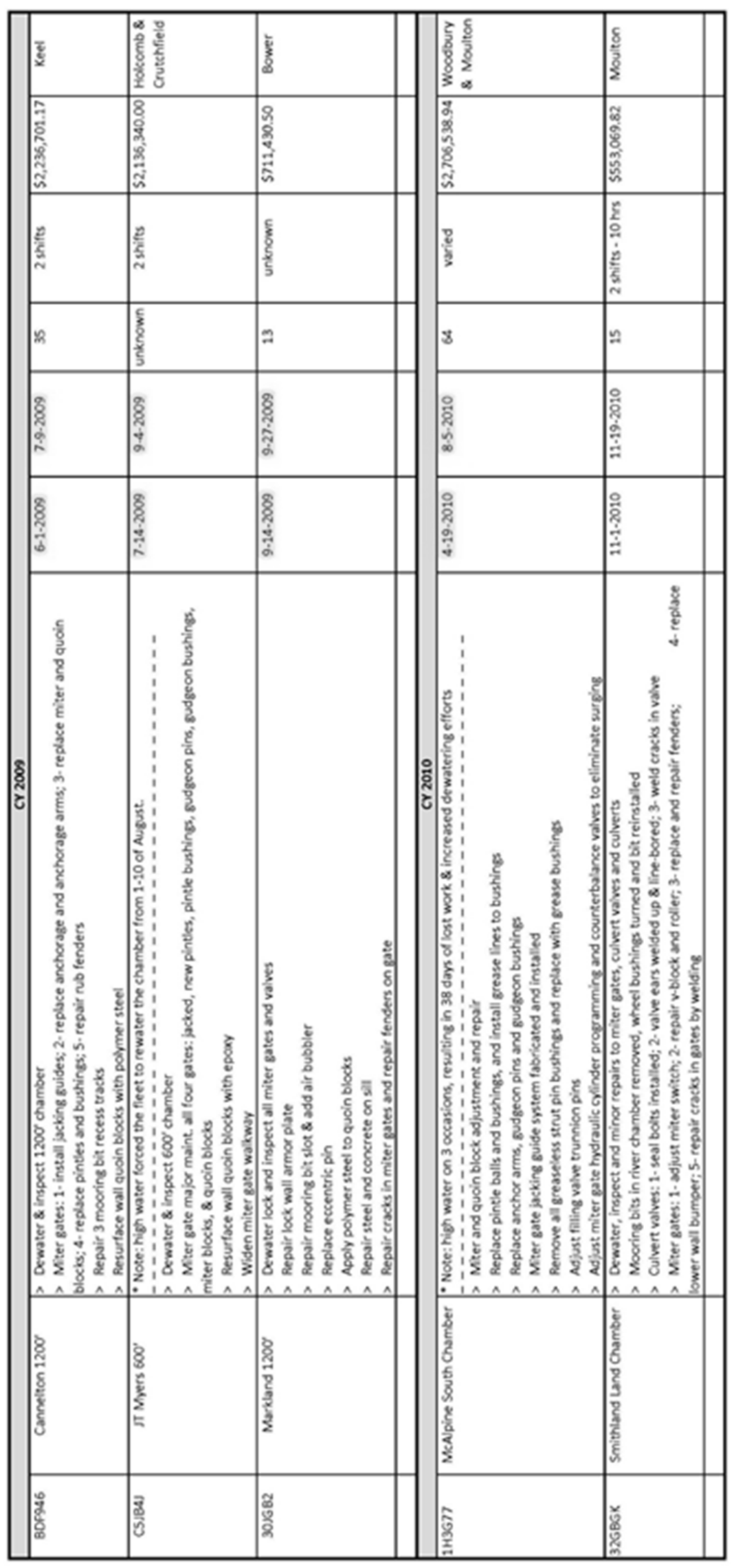




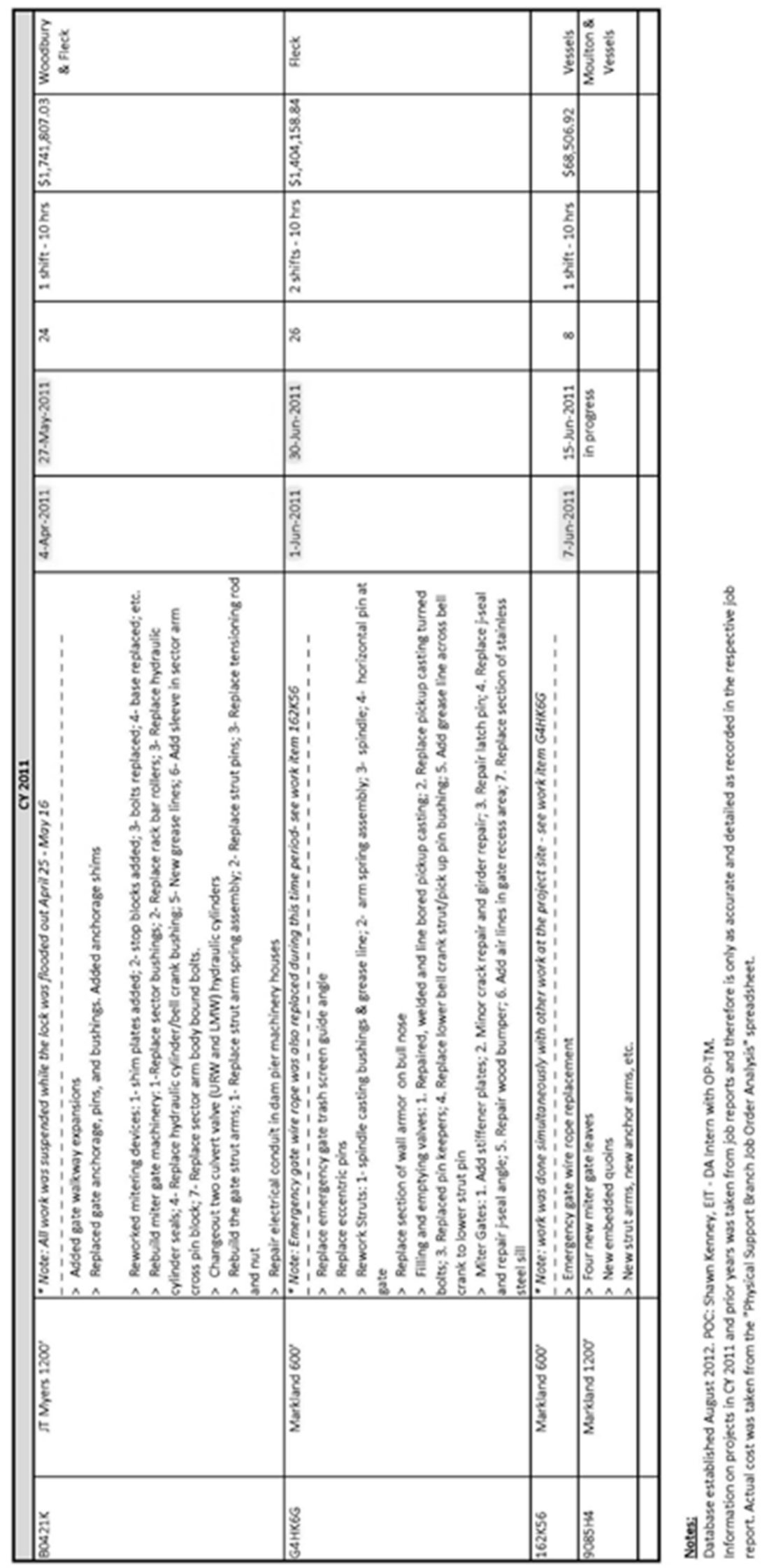




\section{Appendix I: MVD Lock Closure Data}

\begin{tabular}{|c|c|c|c|c|c|c|c|c|c|c|c|c|c|c|c|c|c|c|c|c|c|c|}
\hline 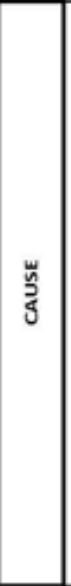 & 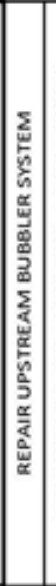 & 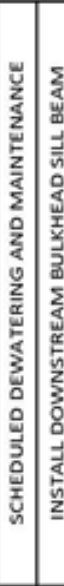 & 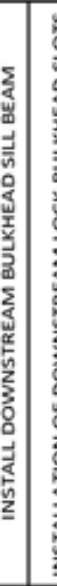 & 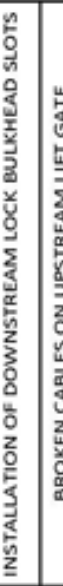 & 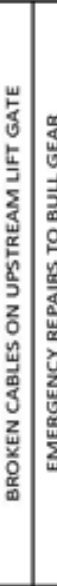 & 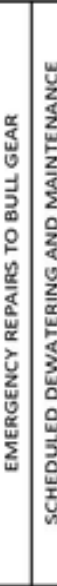 & 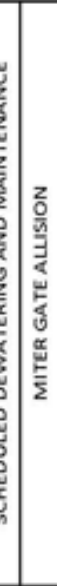 & 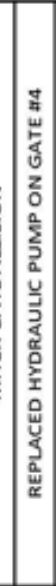 & 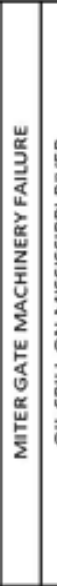 & 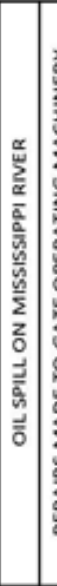 & 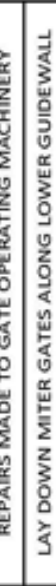 & 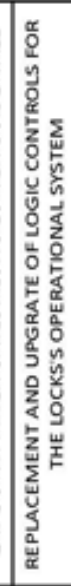 & 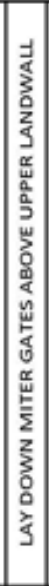 & 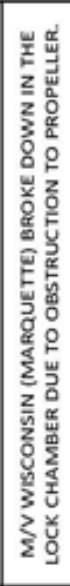 & 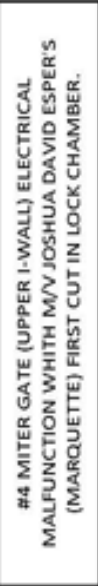 & 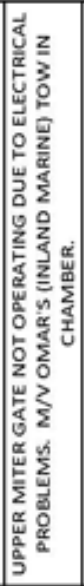 & 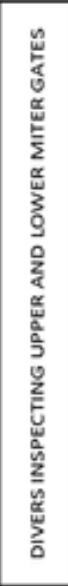 & 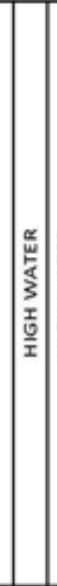 & & & & $\frac{T}{T}$ \\
\hline 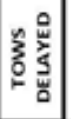 & $\frac{.}{2}$ & 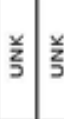 & 窇 & 美 & 恙埭 & $\stackrel{\text { 恙 }}{\mathrm{s}}$ & $\frac{z}{2}$ & $\frac{⿱ 丷}{2}$ & 弟 & 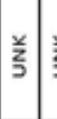 & $\begin{array}{l}\mathbf{z} \\
\end{array}$ & $\stackrel{\text { z }}{\underline{J}}$ & $\mid \frac{z}{z}$ & $N$ & 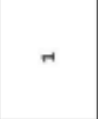 & m & 鸢 & $\mid \begin{array}{l}\frac{x}{2} \\
\frac{2}{5}\end{array}$ & 兰 & $\frac{\stackrel{2}{z}}{2}$ & & 鸢 \\
\hline \begin{tabular}{|l|}
$z$ \\
0 \\
$\bar{z}$ \\
0 \\
$g$
\end{tabular} & 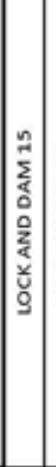 & & & 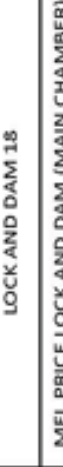 & 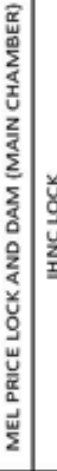 & 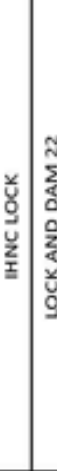 & 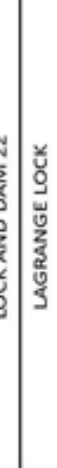 & 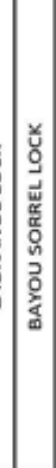 & 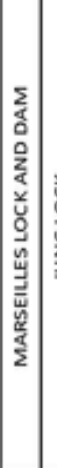 & & 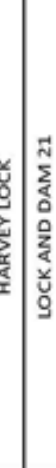 & 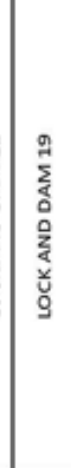 & 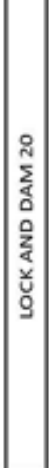 & 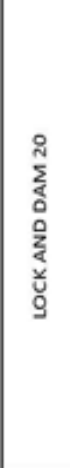 & 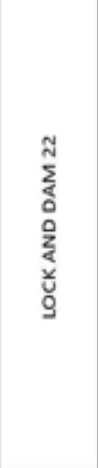 & 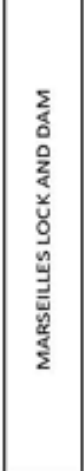 & 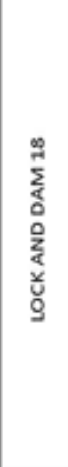 & 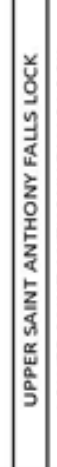 & & & 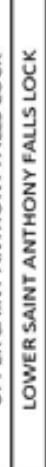 & 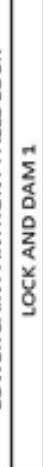 \\
\hline 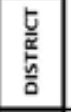 & $\frac{\xi}{2}$ & $\sum$ & $\frac{\pi}{2}$ & $\frac{\pi}{2}$ & $\sum_{\Sigma}^{n}$ & \begin{tabular}{l|l}
$z$ \\
$\Sigma$
\end{tabular} & $\frac{x}{2} \frac{\alpha}{2}$ & $\sum_{z}^{z}$ & $\frac{p}{2}$ & $\frac{z}{z}$ & $\frac{3}{2}$ & $\frac{\tilde{n}}{2}$ & $\frac{\pi}{2}$ & $\frac{\tilde{s}}{2}$ & $\frac{\alpha}{\Sigma}$ & $\frac{\alpha}{\Sigma}$ & $\sum_{\Sigma}^{\frac{\pi}{2}}$ & $\frac{5}{2}$ & $\sum_{\Sigma}^{2}$ & & & $\frac{5}{2}$ \\
\hline 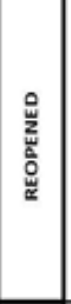 & 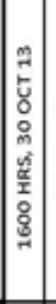 & 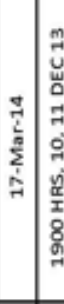 & 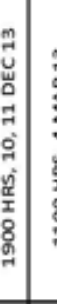 & 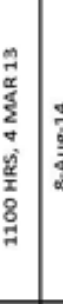 & 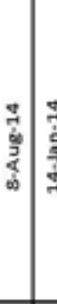 & 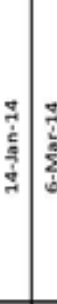 & 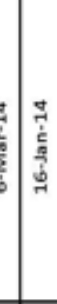 & 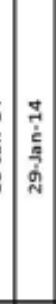 & 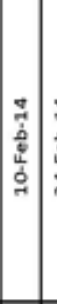 & 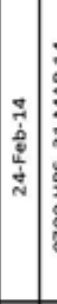 & 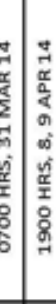 & 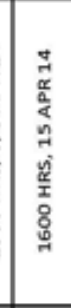 & 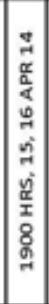 & 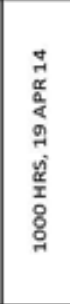 & 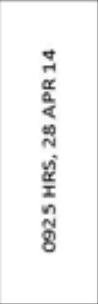 & 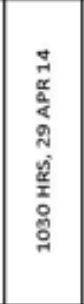 & 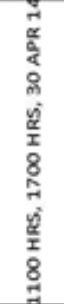 & 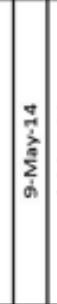 & & & & 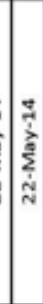 \\
\hline$\stackrel{\text { L }}{\underline{F}}$ & 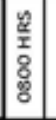 & $\begin{array}{l}\frac{y}{x} \\
8 \\
8 \\
0\end{array}$ & 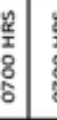 & 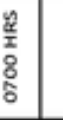 & & & & & & 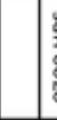 & 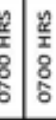 & 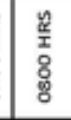 & 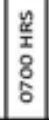 & $\begin{array}{l}\frac{\psi}{\underline{x}} \\
\frac{1}{2} \\
8 \\
8\end{array}$ & 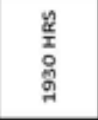 & 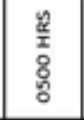 & 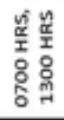 & 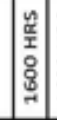 & & & & \\
\hline 岁 & 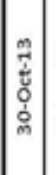 & 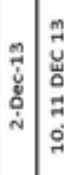 & 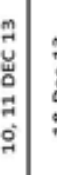 & 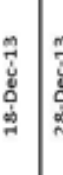 & " & 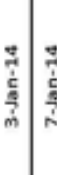 & 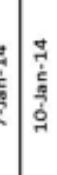 & 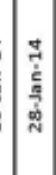 & 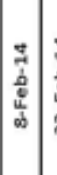 & 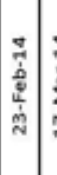 & 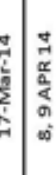 & 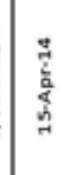 & $\begin{array}{l}\vec{\alpha} \\
\frac{\alpha}{\alpha} \\
\underline{\alpha} \\
\underline{b}\end{array}$ & 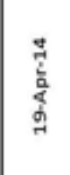 & 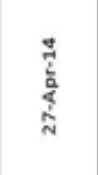 & 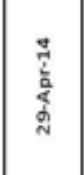 & 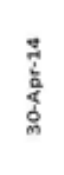 & 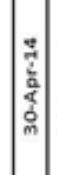 & & & F & \\
\hline
\end{tabular}




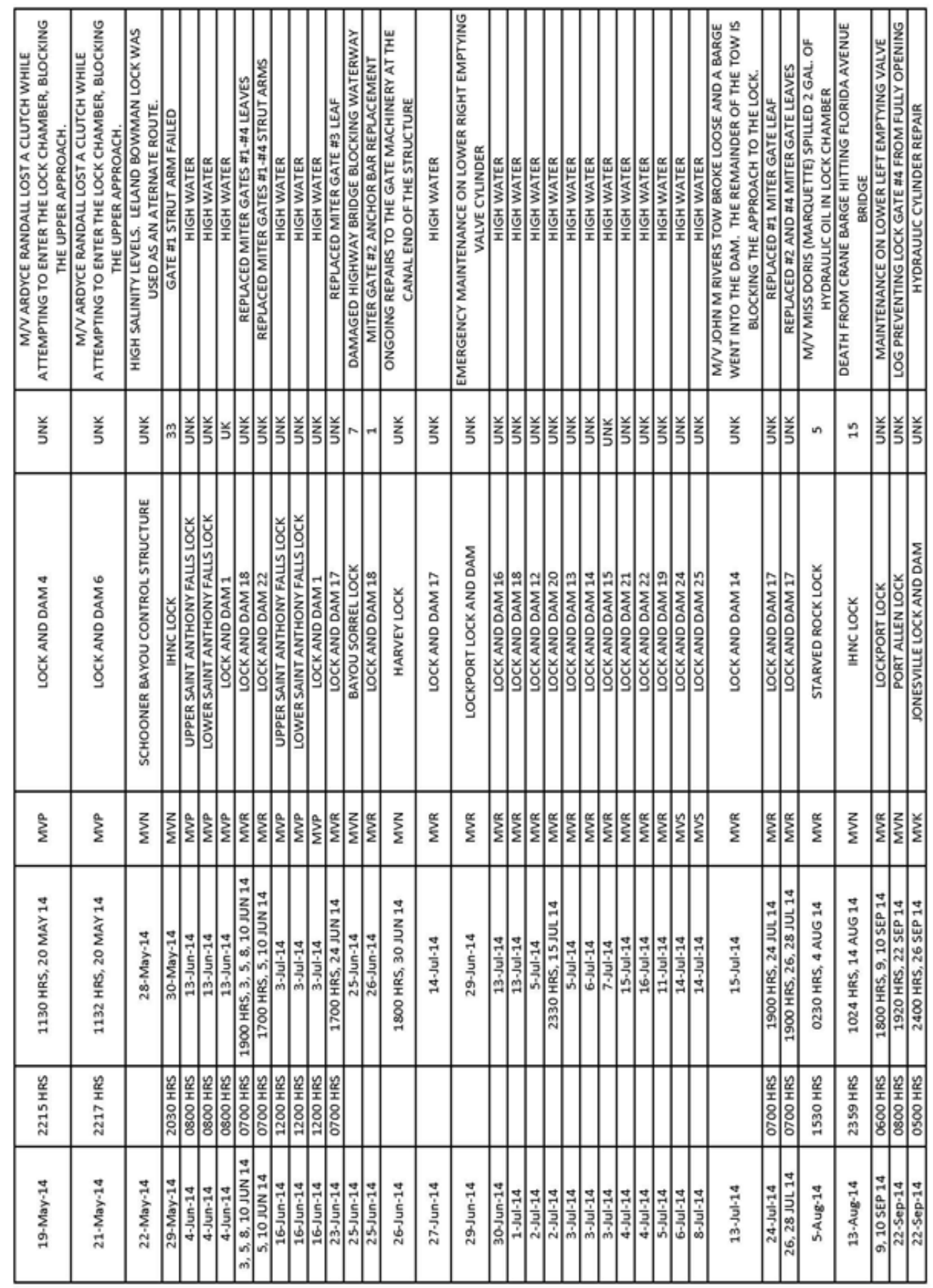




\title{
Appendix J: USACE Lock M\&R Expert Interviews
}

\author{
John C, CELRD
}

These questions should be considered from multiple perspectives to include the operator, structural engineer, maintenance manager, etc.

\section{$\underline{\text { Basic }}$}

What additional information would you like to have on the operational readiness of locks?

The most important information is to know how well the contact blocks transfer load. Poor load transfer is the precursor to most pintle issues and girder cracking so identifying load transfer issues early is key.

What information would help avoid emergency or unscheduled closures?

\section{No input}

\section{More detailed}

What additional information would you like to have for identifying, prioritizing and planning maintenance activities?

\section{Again, the main issue is load transfer. This also includes inte-} rior gate members, not just contact blocks.

Is rotating machinery a concern? Is there adequate redundancy or is the failure rate low enough that there aren't concerns? What is done for scheduled maintenance? Is there-time based maintenance that could be based on cycles or monitored condition?

This is not a big concern, but it would probably be good to monitor motor loads and hydraulic pressure.

Are there fatigue-related issues you need more information for?

\section{It would be good to record the loading cycles and the loads on the gudgeon anchorage.}

What issues do you have with debris? Caught under gate? In the miter? In the quoin and can't close the gate? What happens when the gate closes with debris in quoin? How is it removed? What damage results? 
The main issue is dealing with large debris fields. Otherwise, floating debris mainly just requires patience and use of the bubblers. In $20+$ years Louisville only had issues with debris on the floor about a $1 / 2$ dozen times.

What information would improve management of gate operations in the presence of debris or ice? What types of damage from debris, ice, collisions or other causes would you like to have different, better or more information about? Ice and debris info is not really a concern. Most gates don't have collision issues when recessed. One exception is Cannelton that has a short bullnose. From a repair standpoint the impact load when mitered isn't a concern, but the structural engineer might be interested in that.

- I can talk with Travis A., but do you have a structural engineer you'd recommend I talk to?

- Larry D. in LRL.

\section{Dewatered}

What are the primary concerns for inspection, maintenance and repair when dewatering? What would you like to know before dewatering that you don't?

- Condition of quoin and contact gaps.

Yes, but repair of contact surface is assumed to be needed.

- Cracking of pintle and girders.

\section{It would be good to know about this prior to dewatering}

It would be useful to have better info on wear and slop in the valve trunnions and pins before dewatering to know whether to replace bushings.

When dewatered, what issues are most frequently resolved? Which ones most frequently left unresolved? What external drivers cause issues to be a priority or not addressed?

- Most likely to be unresolved are new or slowly progressing issues that can wait for pre-planned repair during next dewatering.

- Most likely not to be addressed are issues that take longer to repair than the scheduled closure or require manpower/ equipment that is not available. 
Contact block surfacing routinely gets addressed. Serious pintle cracking is the primary unexpected concern.

When dewatered, are pintle issues always addressed or not? Why?

- Depends on dewatering frequency, rate of damage progression, available resources for repair, knowledge of condition before dewatering.

- Other factors?

- Not discussed. Are cracks always welded?

- Yes, cracks would always be welded. If warranted and there was no replacement pintle, the pintle would be removed and sent to a welding shop for crack repair and heat treating.

When dewatered, how often are gaps in quoin blocks not fixed? Why not?

Are miter block gaps less critical?

- In LRD and SAM, quoin gaps are typically filled in.

- In NWP, adjustable blocks take longer to adjust than typical 1 week closures.

- Addressing gaps in contact blocks is considered a critical issue for extending the life of gates, reducing life cycle cost and avoiding unscheduled closure.

Other

Dewatering used to occur every 5 years with longer closures every 15 years. Current policy is to not dewater until rank is high enough in Asset Management. This means good information regarding development of problems is more critical for avoiding unscheduled closure and it is also needed to justify dewatering.

Pintle changes typically mean removing and re-setting contact blocks on gates.

- Would only one pintle be replaced if the other were in ok condition?

No, would always replace in mating pairs.

- If so, would contact blocks on one or both gates be reset?

Contact blocks would be replaced and reset.

Wall quoin blocks are more difficult to reset so they are repaired with Belzona. 
Replacing one gate means replacing both for everything to mate up.

Phil S, CEMVP

These questions should be considered from multiple perspectives to include the operator, structural engineer, maintenance manager, etc.

$\underline{\text { Basic }}$

What additional information would you like to have on the operational readiness of locks?

What information would help avoid emergency or unscheduled closures?

\section{$\underline{\text { More detailed }}$}

What additional information would you like to have for identifying, prioritizing and planning maintenance activities?

From an engineering standpoint, the actual distribution of stresses throughout the structure under the various loading conditions would be a valuable tool in evaluating the suitability of existing conditions. This cannot be understated. Currently, we make assumptions on what these distributions are and can be either overly conservative or dangerously unconservative. Information can be obtained through a variety of means including instrumentation, photogrammatic coatings, LiDAR measurements, etc. This information would also be invaluable in advancing the state of the art of design and evaluation of HSS.

Is rotating machinery a concern? Is there adequate redundancy or is the failure rate low enough that there aren't concerns? What is done for scheduled maintenance? Is there-time based maintenance that could be based on cycles or monitored condition?

Are there fatigue-related issues you need more information for?

What are the fatigue stress cycle magnitudes and frequencies? Current practice is to guess and this can be conservative or not. It would also be useful to know what the stresses really are in the areas of concern. The three areas I see the most problems in HSS are corrosion and section loss, primarily due to lack of maintenance, damage due to impacts or mis-operations, and cracking form fatigue or fracture. The latter can be a nuisance or can lead to failures. A better handle on fatigue loadings would be helpful. 
What issues do you have with debris? Caught under gate? In the miter? In the quoin and can't close the gate? What happens when the gate closes with debris in quoin? How is it removed? What damage results?

Added gravity load, damage during operation (debris gets wedged in a member), creates a good environment for corrosion.

What information would improve management of gate operations in the presence of debris or ice? What types of damage from debris, ice, collisions or other causes would you like to have different, better or more information about?

Ice loading is a big unknown. We do not have a good handle on stresses caused by thermally expanding ice, floating ice, ice acting as gravity.

\section{Dewatered}

What are the primary concerns for inspection, maintenance and repair when dewatering? What would you like to know before dewatering that you don't?

- Condition of quoin and gaps.

- Cracking of pintle and girders.

- Mud and debris need to be cleared if you want to get a good inspection

- Differences of opinion between operators and engineers on what is important

- Any damaged areas, cracks, holes? How do these affect the safety and functionality of the gate and what are the priorities (based on safety and functionality)

When dewatered, what issues are most frequently resolved? Which ones most frequently left unresolved? What external drivers cause issues to be a priority or not addressed?

- Most likely to be unresolved are new or slowly progressing issues that can wait for pre-planned repair during next dewatering.

- Most likely not to be addressed are issues that take longer to repair than the scheduled closure or require manpower/ equipment that is not available.

- Agree with these statements, but we need to assess what IS important and can't wait until next time

When dewatered, are pintle issues always addressed or not? Why? 
- Depends on dewatering frequency, rate of damage progression, available resources for repair, knowledge of condition before dewatering.

- Other factors?

When dewatered, how often are gaps in quoin blocks not fixed? Why not?

Are miter block gaps less critical?

- In LRD and SAM, quoin gaps are typically filled in.

- In NWP, adjustable blocks take longer to adjust than typical 1 week closures.

- MVP has vertically framed gates. J ust pretend they are vertically framed and you don't need to worry about quoins.

Allen D, CESAM

These questions should be considered from multiple perspectives to include the operator, structural engineer, maintenance manager, etc.

\section{$\underline{\text { Basic }}$}

What additional information would you like to have on the operational readiness of locks?

I have developed and proposed a lock gate rating guide (including structural and coating) similar to that used in bridge inspection, tailored to miter gates. It has ten very descriptive ratings, that could be used to schedule the necessary frequency of inspection, and it clearly describes where the weaknesses are. This is also very useful to Operations personnel in knowing the relative condition of their project to others and where the problems are.

What information would help avoid emergency or unscheduled closures?

A similar inspection and rating guide could possibly be developed for mechanical issues.

\section{More detailed}

What additional information would you like to have for identifying, prioritizing and planning maintenance activities?

Implementation of the above rating guides, also careful monitoring of quoin block gap conditions. The monitoring of miter gate anchor arm movement, we use dual axis inclinometers and 
laser levels, with very good results in predicting which anchor arms are likely to develop cracking.

Is rotating machinery a concern? Is there adequate redundancy or is the failure rate low enough that there aren't concerns? What is done for scheduled maintenance? Is there-time based maintenance that could be based on cycles or monitored condition?

Are there fatigue-related issues you need more information for?

In general better documentation of specific locations where cracks have been found and which have been repaired. Description of length and orientation etc., this may help in future planning of repairs or in identifying the cause of cracking especially for cracks that are associated with each other. Also the cathodic protection system status and history along with the coating system and water resistivity greatly affect fatigue crack development. In general in a corrosive environment with no CP and inadequate coating the fatigue cracking will likely be much more extensive.

What issues do you have with debris? Caught under gate? In the miter? In the quoin and can't close the gate? What happens when the gate closes with debris in quoin? How is it removed? What damage results?

Some projects have a lot of scalloped flange edges on the bottom girder, but no serious structural damage. Our Operations personnel would have a lot of knowledge of this issue, but have not relayed any concerns to me. The air blowers seem to work well and I have seen them open and close the gates when an obstruction occurs until it dislodges.

What information would improve management of gate operations in the presence of debris or ice? What types of damage from debris, ice, collisions or other causes would you like to have different, better or more information about?

\section{Dewatered}

What are the primary concerns for inspection, maintenance and repair when dewatering? What would you like to know before dewatering that you don't?

- Condition of quoin and gaps.

- Cracking of pintle and girders.

- The rating guide proposed in the above, also our Operations personnel are very good, experienced, and very dedicated. 
They know what to expect and work closely with Engineering.

- One waterway system is now using a diver and aluminum foil to measure quoin block gaps in the wet.

- Development or deployment of acoustic photo technology or other methods to get a preview of the cracking extent would certainly be helpful to the projects in lining up men and equipment to accomplish the needed repairs in the limited time available.

- A very important consideration that Engineers should be aware of is that the Operations personnel have a lot of work to do in a short time, men and equipment are tied up with critical work. The inspector will need man lifts, power washing etc. and other assistance at times, he needs to minimize any work delays. He needs to "know well" the difference between trivial and serious.

When dewatered, what issues are most frequently resolved? Which ones most frequently left unresolved? What external drivers cause issues to be a priority or not addressed?

- Most likely to be unresolved are new or slowly progressing issues that can wait for pre-planned repair during next dewatering.

- Most likely not to be addressed are issues that take longer to repair than the scheduled closure or require manpower/ equipment that is not available.

When dewatered, are pintle issues always addressed or not? Why?

- Depends on dewatering frequency, rate of damage progression, available resources for repair, knowledge of condition before dewatering.

- Other factors?

- The quoin and pintle areas are typically the first thing we look at. The condition of these areas can mean calling in additional personnel and equipment for repairs.

When dewatered, how often are gaps in quoin blocks not fixed? Why not?

Are miter block gaps less critical?

- In LRD and SAM, quoin gaps are typically filled in.

- In NWP, adjustable blocks take longer to adjust than typical 1 week closures.

- In the past some projects focused on the miter blocks as far as resurfacing, probably thinking that they are easier to get to and accomplish the same thing. They were incorrect; a 
gap in the miter will only mean that the gate will tend to miter a little further downstream. However a gap between the quoin blocks will do serious damage probably beginning at about $1 / 8^{\prime \prime}$ gap if left for a long time period. $A$ 1/4" or more gap would probably do very severe damage in a short period of time

Travis A, CENWP

These questions should be considered from multiple perspectives to include the operator, structural engineer, maintenance manager, etc.

\section{$\underline{\text { Basic }}$}

What additional information would you like to have on the operational readiness of locks?

Not just is the gate fully mitered, but what about fully open as well? There is a history of slop in operating equipment creating a situation where the gates are not fully retracted. This has resulted in damage to the timbers and ends of the gate. We need to know that the gates are fully mitered and fully retracted.

What information would help avoid emergency or unscheduled closures?

Pintle condition (bolts), Quoin block condition, miter block condition. In addition to this we have had several electrical issues in terms of contact/limit switches. The switches are on the arms out over the center of the lock that require a manbasket to access. Knowing where the switch is bad would assist with these unscheduled outages.

\section{$\underline{\text { More detailed }}$}

What additional information would you like to have for identifying, prioritizing and planning maintenance activities?

Block wear rates, adjustment/ contact information.

Is rotating machinery a concern? Is there adequate redundancy or is the failure rate low enough that there aren't concerns? What is done for scheduled maintenance? Is there-time based maintenance that could be based on cycles or monitored condition?

There is annual maintenance on these components. I don't know how many have failed, but I would imagine contact wear on the teeth. 
Are there fatigue-related issues you need more information for?

Quoin post cracking is initially fracture that results from torsion on the quoin post due to lack of block contact. This cracking grows with each lockage and it is unclear at what rate cracks will grow in old steel because toughness and actual level of stress is unknown.

What issues do you have with debris? Caught under gate? In the miter? In the quoin and can't close the gate? What happens when the gate closes with debris in quoin? How is it removed? What damage results?

I know we have debris in the chamber at Bonneville and the Dalles, but I have not heard of it getting caught. This would be an ops question.

What information would improve management of gate operations in the presence of debris or ice? What types of damage from debris, ice, collisions or other causes would you like to have different, better or more information about?

We don't have ice. For debris it would simply be to know if the gate is caught on something.

\section{Dewatered}

What are the primary concerns for inspection, maintenance and repair when dewatering? What would you like to know before dewatering that you don't?

- Condition of quoin and gaps. - yes. Need to know gap for adjustment

- Cracking of pintle and girders. - yes- cracking at both locations is common.

When dewatered, what issues are most frequently resolved? Which ones most frequently left unresolved? What external drivers cause issues to be a priority or not addressed?

- Most likely to be unresolved are new or slowly progressing issues that can wait for pre-planned repair during next dewatering.

- Most likely not to be addressed are issues that take longer to repair than the scheduled closure or require manpower/ equipment that is not available.

The real issue I see with this question is that on the Columbia River the dewaterings are supposed to be every 10 years. So what can wait ten years? There are many things that can wait a year, but waiting 10 years is not acceptable for many issues associated with cracking or block alignment. 
When dewatered, are pintle issues always addressed or not? Why?

- Depends on dewatering frequency, rate of damage progression, available resources for repair, knowledge of condition before dewatering.

- Other factors?

We find loose bolts - we can tighten them or replace them - but unless we know about it beforehand, we are not ready to replace parts. We only have 2 week outages, which take 3 days on each end to dewater or rewater ... so there isn't time to react and order bolts etc.

When dewatered, how often are gaps in quoin blocks not fixed? Why not?

Are miter block gaps less critical?

- In LRD and SAM, quoin gaps are typically filled in.

- In NWP, adjustable blocks take longer to adjust than typical 1 week closures.

Takes too long to adjust blocks or fill gaps. Our gates are 100 feet tall. Belzona will crush under load so we cannot use it with 90 feet of head. We also don't have sufficient time to place it because cranes cannot reach the center of the locks with equipment and manbaskets to adjust the gap in the closed position such that we could pour against the other side of the miter for a mold. So we need scaffolding that we cannot get installed and fixed and removed in 2 weeks. So planning ahead for a special outage either to adjust blocks or fill gaps is critical.

\section{Anthony P, CESAM}

These questions should be considered from multiple perspectives to include the operator, structural engineer, maintenance manager, etc.

\section{$\underline{\text { Basic }}$}

What additional information would you like to have on the operational readiness of locks?

I look at these two questions as the same. If there is additional information for readiness, that information would help avoid emergency or unscheduled closures. Cost/ funding vs. downtime/ consequences is always a driver. In districts with dual chambers this is not as much of a concern, but in SAM we have only single chambers so equipment failure leads to closing of the river. We have PLC control systems for lock operation. Additional information would be in the form of indicators of early signs of equipment failure, i.e. audio indicators (gudgeon pin pops when binding or improperly greased, unusual sounds from machinery that normally indicate a 
problem), vibration indicators, stress/ stain gauges on components that provide indication of abnormal stresses (anchorage links, operating arms, miter gates). Only problem with indicators is the durability of the instruments and long term reliability. Again, any early warning signs on equipment could prevent unscheduled closures.

What information would help avoid emergency or unscheduled closures? Same as above

\section{More detailed}

What additional information would you like to have for identifying, prioritizing and planning maintenance activities?

See answer above. Also add monitoring of cracks in hydraulic structures (miter gates). Again this equipment is usually high cost and not durable for our environments.

\section{Is rotating machinery a concern?}

Yes and No, most of our machinery is slow moving so not many concerns with normal operation. Of course the size is large and we have high stresses and loading in machinery for miter gates. Loading is main concern that can lead to cracks in structure or components.

Is there adequate redundancy or is the failure rate low enough that there aren't concerns?

Redundancy is only in the lock valves (or spillway gates due to numbers). If problem occurs in one lock valve, that valve can be isolated and repaired without a closure of the lock. With the miter gates, there is no redundancy.

What is done for scheduled maintenance?

If issue is discovered, and does not immediately have to be repaired, then users can be notified and a closure can be coordinated with little impact. It's the unscheduled, immediate, need of a closure that impacts the users. However, if the repairs require extended time to repair then the users are impacted if not given a long enough lead time to prepare of the closure (a 15-30-day closure is normally coordinated a year in advance).

Is there-time based maintenance that could be based on cycles or monitored condition?

All equipment has cycle limitations. For example, we inspect anchorage links every three years and normally cracks are found on locks with the highest cycles. 
Are there fatigue-related issues you need more information for?

Anchorage Links are one component that has to be monitored for cracks. Miter gates also, but can't be monitored as often due to fact that high stress areas are under water. De-waterings don't occur but every 5-10 years (more likely 10 years).

What issues do you have with debris?

Lots of debris that collects above spillway gates. Has to be passed through gates, which results in tore bottom seals. Do have one debris gate at RF Henry Lock and one at Millers Ferry powerhouse. Debris is also present in the locks, but we have air systems that blow/ push debris from behind the gates prior to operation. Debris in the lock culverts damages the valve components and grease lines (many of the steel guards over the intakes have corroded and are missing).

Caught under gate? Sometimes, but rare. Have to cycle the gates several times to move debris or dislodge it.

In the miter? Sometimes, but rare. Have to cycle the gates several times to move debris or dislodge it.

In the quoin and can't close the gate? No, due to having air systems for quoin areas and gate recess areas.

What happens when the gate closes with debris in quoin? If occurred, the SAM gates are designed with floating pintle, so the pintle shoe/ ball could move out to prevent damage to the gate. Once removed or dislodged, the gate would move back into its normal position.

is it removed? Either cycling of gates (move back and forth) or personnel with poles or hooks; from small boat or floating plant.

What damage results? None, if floating pintle design works (don't see why it would not work). However, if the log or object is large, then it would be possible to have enough movement in the gate to cause damage the anchorage link.

What information would improve management of gate operations in the presence of debris or ice? We don't have ice issues in SAM. Don't know of any information that would help on debris.

What types of damage from debris, ice, collisions or other causes would you like to have different, better or more information about? Damage from debris inside lock valve culverts is hard or impossible to detect. 
Therefore, you could have grease lines broken and not know until the machinery starts making noise or vibrates.

\section{Dewatered}

What are the primary concerns for inspection, maintenance and repair when dewatering? Any normally underwater structures or components; pintle assembly condition, miter gate structure integrity, condition of paint, contact block surface condition, contact block gap, grease lines.

What would you like to know before dewatering that you don't? all of the above conditions

- Condition of quoin and gaps.

- Cracking of pintle and girders.

Past experience has proven that if you have a gap in the quoin and miter blocks that you could have cracks in the pintle socket and/ or bottom gate girder and also broken pintle bolts (more load into the pintle that designed for).

When dewatered, what issues are most frequently resolved? Which ones most frequently left unresolved? What external drivers cause issues to be a priority or not addressed?

- Most likely to be unresolved are new or slowly progressing issues that can wait for pre-planned repair during next dewatering.

- Most likely not to be addressed are issues that take longer to repair than the scheduled closure or require manpower/ equipment that is not available.

Of course the more issues or required maintenance that you are aware of, the more you can plan for and be prepared to accomplish during a scheduled de-watering. At SAM, we normally de-water a lock every 10 years unless a known issue exists that requires a major closure. Major closures are normally scheduled for 30-days and we do not have dual chambers so we have to perform the maintenance within that time frame and get the lock back on-line for the users. If we discover a major issue that needs to be addressed without waiting for another closure, we will coordinate with the users for extension (very rare); if the issue is justified and possible consequences verified, if not resolved immediately. Most of the time a major issue discovered during the closure can be repaired during current closure time, and if needed, a temporary repair can be made with a permanent repair postponed to later closure; less impact on the users. Anything we can do to prevent impact to the waterway users is first priority, and at the same time repair and maintain the equipment to the best condition possible. 
When dewatered, are pintle issues always addressed or not? Why?

- Depends on dewatering frequency, rate of damage progression, available resources for repair, knowledge of condition before dewatering.

- Other factors?

With the pintle being the major component of the miter gate, any issue with the pintle is addressed (and first thing inspected). Sometimes you may have to make a temporary repair until a permanent repair or replacement can be properly scheduled.

When dewatered, how often are gaps in quoin blocks not fixed? Why not?

Are miter block gaps less critical?

- In LRD and SAM, quoin gaps are typically filled in.

- In NWP, adjustable blocks take longer to adjust than typical 1 week closures.

A gap in the quoin or miter blocks is bad; can cause damage to the pintle. Therefore we go into every lock closure prepared to correct contact block gap issues. If cracks in the pintle or broken pintle bolts are found, you know you probably have contact block gap issues and we also check the gap. If gap is discovered we re-surface the contact blocks with Belzona material. We have been using Belzona material for many years (15+years) with great success.

\section{Fred J , CEMVR}

These questions should be considered from multiple perspectives to include the operator, structural engineer, maintenance manager, etc.

\section{$\underline{\text { Basic }}$}

What additional information would you like to have on the operational readiness of locks?

What information would help avoid emergency or unscheduled closures?

For both of these it would help to have better information on history of what has caused "failures" in the past and what are the most common things that have maintenance or repair issues

\section{$\underline{\text { More detailed }}$}

What additional information would you like to have for identifying, prioritizing and planning maintenance activities? 
We do not perform systematic or regular dewatering so getting information on submerged components would be a benefit.

Is rotating machinery a concern? Is there adequate redundancy or is the failure rate low enough that there aren't concerns? What is done for scheduled maintenance? Is there-time based maintenance that could be based on cycles or monitored condition?

Are there fatigue-related issues you need more information for?

We have fatigue issues with gates, but I don't think we have a good handle on the stresses.

What issues do you have with debris? Caught under gate? In the miter? In the quoin and can't close the gate? What happens when the gate closes with debris in quoin? How is it removed? What damage results?

What information would improve management of gate operations in the presence of debris or ice? What types of damage from debris, ice, collisions or other causes would you like to have different, better or more information about? We could use more information on the loading conditions caused by moving gates through heavy ice.

\section{Dewatered}

What are the primary concerns for inspection, maintenance and repair when dewatering? What would you like to know before dewatering that you don't?

- Condition of quoin and gaps.

- Cracking of pintle and girders.

In general our dewatering are infrequent so we do not have much information on the underwater parts before dewatering, therefore planning repairs is problematic.

Hard to get a handle on loss of section from corrosion, pitting is common, and its effect on the structure. Lack of time and funding

When dewatered, what issues are most frequently resolved? Which ones most frequently left unresolved? What external drivers cause issues to be a priority or not addressed?

- Most likely to be unresolved are new or slowly progressing issues that can wait for pre-planned repair during next dewatering. correct 
- Most likely not to be addressed are issues that take longer to repair than the scheduled closure or require manpower/ equipment that is not available. Correct. Funding is issue also

When dewatered, are pintle issues always addressed or not? Why?

- Depends on dewatering frequency, rate of damage progression, available resources for repair, knowledge of condition before dewatering.

- Other factors?

When dewatered, how often are gaps in quoin blocks not fixed? Why not?

Are miter block gaps less critical?

- In LRD and SAM, quoin gaps are typically filled in.

- In NWP, adjustable blocks take longer to adjust than typical 1 week closures. 


\section{References}

Farrar, Charles R., and Keith Worden. 2013. Structural Health Monitoring: A Machine Learning Perspective. New York: Wiley \& Sons.

Foltz, Stuart D.; Bislip-Morales, Carlos B.; Hammack, E. Allen. 2013. Asset Management and Facility Equipment Maintenance Nexus: Maintenance Effectiveness, ERDC TR 13-16. Champaign, IL: Engineer Research and Development Center, Construction Engineering Research Laboratory (ERDC-CERL), https://erdc-library.erdc.dren.mil/xmlui/bitstream/handle/11681/8600/ERDC-TR-1316.pdf? sequence $=1$ \&isAllowed $=y$

Headquarters, U.S. Army Corps of Engineers (HQUSACE). 2016. Navigation. Web page, http://www.usace.army.mil/Missions/CivilWorks/Navigation.aspx

1996. Navigation and Dredging Operations and Maintenance Guidance and Procedures. EP 1130-2-520. Washington, DC: HQUSACE, http://www.publications.usace.army.mil/Portals/76/Publications/EngineerPamphlets/EP_1130 -2-520.pdf

IBM. 2016. Maximo Asset Management. Website, http://www-03.ibm.com/software/products/en/maximoassetmanagement/

IMTS Capital Investment Strategy Team. 2010. Inland Marine Transportation Systems (IMTS) Capital Projects Business Model. http://www.iwr.usace.army.mil/Portals/70/docs/Wood_doc/IMTS_Final_Report_13_April_201 $\underline{0 \_\operatorname{Rev} 1 . p d f}$

U.S. Army Corps of Engineers (USACE). 2011. Sustainable Solutions to America's Water Resources Needs: Civil Works Strategic Plan 2011-2015. Washington, DC: USACE.

2011. Department of the Army U.S. Army Corps of Engineers Civil Works Program Five-Year Development Plan Fiscal Year 2011 to Fiscal Year 2015, http://www.usace.army.mil/Portals/2/docs/civilworks/5yr_devplan/fy11_5yrplan.pdf 


\title{
Acronyms and Abbreviations
}

\author{
Term \\ Definition \\ ERDC \\ U.S. Army Engineer Research and Development Center \\ ERDC-CERL \\ Engineer Research and Development Center, Construction Engineering \\ Research Laboratory \\ EROC \\ Engineer Reporting Organization Code \\ FEM \\ Facilities Equipment and Maintenance \\ HQUSACE \\ Headquarters, U.S. Army Corps of Engineers \\ LPMS \\ Lock Performance Monitoring System \\ LRD \\ USACE Great Lakes and Ohio River Division \\ LRL \\ USACE Louisville District \\ $M \& R$ \\ Maintenance and Repair \\ MVD \\ USACE Mississippi Valley Division \\ O\&M \\ $\mathrm{SF}$ \\ Operations and Maintenance \\ TR \\ Standard Form \\ Technical Report \\ USACE \\ U.S. Army Corps of Engineers
}




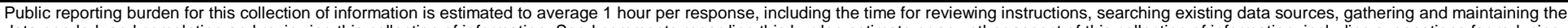

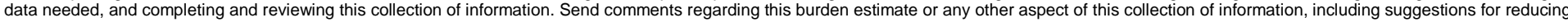

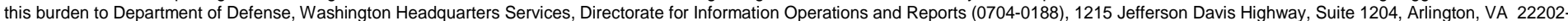

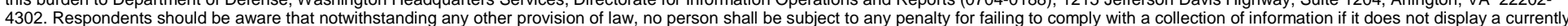
4302. Respondents should be aware that notwithstanding any other provision of law, no person sha
valid OMB control number. PLEASE DO NOT RETURN YOUR FORM TO THE ABOVE ADDRESS.

\begin{tabular}{l|l} 
valid OMB control number. PLEASE DO NOT RETURN YOUR FORM TO THE ABOVE ADDRESS. \\
\hline 1. REPORT DATE (DD-MM-YYYY)
\end{tabular}

\begin{tabular}{|r|r}
$06 / 05 / 2017$ & Final \\
\hline
\end{tabular}

4. TITLE AND SUBTITLE

Final

Investigation of Mechanical Breakdowns Leading to Lock Closures

(1)

5a. CONTRACT NUMBER

5b. GRANT NUMBER

5c. PROGRAM ELEMENT

6. AUTHOR(S)

Stuart D. Foltz

\section{5d. PROJECT NUMBER}

5e. TASK NUMBER

5f. WORK UNIT NUMBER

1F18B1, L93CJ 7, 4B1176

7. PERFORMING ORGANIZATION NAME(S) AND ADDRESS(ES)

U.S. Army Engineer Research and Development Center (ERDC)

Construction Engineering Research Laboratory (CERL)

8. PERFORMING ORGANIZATION REPORT

PO Box 9005,

Champaign, IL 61826-9005

NUMBER

ERDC/ CERL TR-17-17

\section{SPONSORING I MONITORING AGENCY NAME(S) AND ADDRESS(ES)}

Headquarters, U.S. Army Corps of Engineers

$441 \mathrm{G}$ St., NW

Washington, DC 20314-1000

10. SPONSOR/MONITOR'S ACRONYM(S)

CEERD-HT

11. SPONSOR/MONITOR'S REPORT NUMBER(S)

\section{DISTRIBUTION I AVAILABILITY STATEMENT}

Approved for public release; distribution is unlimited.

\section{SUPPLEMENTARY NOTES}

\section{ABSTRACT}

The U.S. Army Corps of Engineers (USACE) owns or operates 236 locks at 191 sites, more than half of which have surpassed their 50year design life. There are increasing concerns about their continued safe, reliable operation into the future, especially considering the fact that routine maintenance, lock dewaterings, and inspections sometimes occur at less than optimal intervals. Although critical repairs are prioritized, delayed maintenance increases the risk of failures that result in lock closures. One significant factor that contributes greatly to the difficulty of lock condition assessment is that much of the lock infrastructure typically remains under water. When a lock is dewatered, it is common to find previously unidentified distress, deterioration, and damage. To address such maintenance issues, there is an increasing need to gather more accurate information on repair needs and to prioritize those repairs. This work investigated types and frequencies of lock failures so that sensors can be used more effectively to identify imminent lock operational failures and concerns for ongoing lock reliability. Numerous data sources were used to collect these data, even though most of these sources were not created for the purpose of collecting the type of data the work investigated. The data gap is also discussed in the report.

\section{SUBJECT TERMS}

Hydraulic structures, Structural failures, Locks (Hydraulic engineering), Service life (Engineering), Maintenance and repair

\section{SECURITY CLASSIFICATION OF:}

\section{a. REPORT}

Unclassified

\section{b. ABSTRACT}

Unclassified

\section{LIMITATION} OF ABSTRACT

\section{c. THIS PAGE}

Unclassified
18. NUMBER OF PAGES

104 19a. NAME OF RESPONSIBLE PERSON

19b. TELEPHONE NUMBER

(include area code) 